\title{
The Odyssey of Bioactive Compounds in Avocado (Persea americana) and Their Health Benefits
}

\author{
Deep Jyoti Bhuyan ${ }^{1, *}$, Muhammad A. Alsherbiny ${ }^{1,2}{ }^{(0)}$, Saumya Perera ${ }^{1}$, Mitchell Low ${ }^{1}(\mathbb{D}$, \\ Amrita Basu ${ }^{3}$, Okram Abemsana Devi ${ }^{4}$, Mridula Saikia Barooah ${ }^{4}$, Chun Guang Li ${ }^{1}$ and \\ Konstantinos Papoutsis 5 (D) \\ 1 NICM Health Research Institute, Western Sydney University, Penrith, NSW 2751, Australia; \\ muhammad.alsherbiny@pharma.cu.edu.eg or m.alsherbiny@westernsydney.edu.au (M.A.A.); \\ Saumya.P@westernsydney.edu.au (S.P.); Mitchell.Low@westernsydney.edu.au (M.L.); \\ C.Li@westernsydney.edu.au (C.G.L.) \\ 2 Department of Pharmacognosy, Faculty of Pharmacy, Cairo University, Cairo 11562, Egypt \\ 3 Research Centre for Toxic Compounds in the Environment, Masaryk University, Brno 62500, Czech; \\ amrita@recetox.muni.cz \\ 4 Department of Food Science and Nutrition, College of Community Science, Assam Agricultural University, \\ Assam 785013, India; okramabemsana@gmail.com (O.A.D.); mridulabarooah@aau.ac.in (M.S.B.) \\ 5 School of Agriculture and Food Science, University College Dublin, Belfield, Dublin 4, Ireland; \\ kostas.papoutsis@ucd.ie \\ * Correspondence: d.bhuyan@westernsydney.edu.au or deepjyoti.bhuyan@uon.edu.au; Tel.: +61-2-4620-3508
}

Received: 11 September 2019; Accepted: 23 September 2019; Published: 24 September 2019

\begin{abstract}
Persea americana, commonly known as avocado, has recently gained substantial popularity and is often marketed as a "superfood" because of its unique nutritional composition, antioxidant content, and biochemical profile. However, the term "superfood" can be vague and misleading, as it is often associated with unrealistic health claims. This review draws a comprehensive summary and assessment of research performed in the last few decades to understand the nutritional and therapeutic properties of avocado and its bioactive compounds. In particular, studies reporting the major metabolites of avocado, their antioxidant as well as bioavailability and pharmacokinetic properties, are summarized and assessed. Furthermore, the potential of avocado in novel drug discovery for the prevention and treatment of cancer, microbial, inflammatory, diabetes, and cardiovascular diseases is highlighted. This review also proposes several interesting future directions for avocado research.
\end{abstract}

Keywords: avocado; Persea americana; metabolites; antioxidants; anticancer; antimicrobial; anti-inflammatory; diabetes; cardiovascular diseases (CVD); bioavailability and pharmacokinetic

\section{Introduction}

Persea americana (commonly known as avocado, avocado pear, or alligator pear) is native to Mexico and Central America, and a member of the flowering plant family Lauraceae [1,2]. Botanically, avocado fruit is a berry with a single large seed [3]. Mexico is the leading producer of avocados worldwide [2]. The term "superfood" refers to foods that are beneficial to human health due to their high levels of nutrients and/or bioactive phytochemicals such as antioxidants [4]. In particular, avocado has recently gained dramatic popularity [5] and is often referred to as a "superfood" because of its unique nutritional and phytochemical composition compared to other fruits. This has led to an exponential increase in avocado consumption from 2.23 pounds per capita in 2000 to 7.1 pounds per capita in 2016 in the United States [6]. However, the term "superfood" has been used ambiguously in popular media, and often marketed with misleading health claims of preventing and curing ailments. Considering 
their immense popularity and diverse biochemical content, avocados have also been extensively used in the food, nutraceutical, pharmaceutical, and cosmetic industries. In addition, their health-benefiting properties have been investigated in a number of preclinical and clinical studies in the last few decades. The present review article is focused on the comprehensive summary and assessment of research performed to understand the role of avocado and its bioactive compounds in the prevention and treatment of various ailments, including cancer, microbial, inflammatory, diabetes and cardiovascular diseases. The studies emphasizing the nutritional composition of avocado, its major metabolites, and their pharmacokinetic properties are also reviewed and summarized. Furthermore, this review highlights several interesting aspects for future research on avocado.

\subsection{The Vast Array of Secondary Metabolites of Avocado and Their Biological Significance}

Using "Avocado" and "Persea" as search descriptors with a focus for pharmacologically active metabolites, various avocado metabolites were retrieved from Combined Chemical Dictionary v23.1 (CCD) [7] and The Human Metabolite Database (HMDB) [8]. In addition to the P. americana, the search strategy also covered other Persea species such as P. mexicana, P. indica, P. gratissima, P. obovatifolia, and P. borbonia (Table 1). As per the literature, most bioactive compounds were isolated predominantly from $P$. americana. Other synonyms of P. americana are P. gratissima, Laurus persea, P. drymifolia, and P. nubigena [9]. The metabolite arsenal can be classified chemically into eight main classes, including fatty alcohols, furan derivatives, carotenoids, carbohydrate, diterpenoids, lignan derivatives, and miscellaneous compounds, as shown in Figures 1-8, and Table 1. In brief, fatty alcohols isolated from avocado showed different degrees of unsaturation and alkyl chain length with several levels of hydroxylation and subsequent acetylation (Figure 1). These fatty alcohols have been reported to exhibit antiviral, cytotoxic, antifungal, trypanocidal, and antioxidant activity [10-21]. Phenolic compounds (Figure 2, and Table 1) of different chemical classes from simple organic acids such as gallic acid to larger flavonoids, anthocyanidins, and tocopherols were isolated from Persea species with significant antioxidant, neuroprotective and cardioprotective activities [22-28]. The antioxidant properties of avocado were also ascribed to their carotenoid content in many studies [24,28-30] (Figure 3). Moreover, sugar alcohol and ketoses with variable carbon chain length were isolated from avocado (Figure 4). Notable insecticidal, cytotoxic, and antifungal activities were also reported for the furan and furanone derivatives isolated from Persea species [18,31-37] (Figure 5), where the saturation of the furan ring was detrimental for the insecticidal activity [38]. The insecticidal activity of the furan derivatives was augmented by the diterpenoids compounds [39-43], especially in P. indica (Figure 6). Overall, avocado contains a vast array of secondary metabolites of different chemical classes which may attribute to its diverse biological activities. 
Table 1. Metabolites isolated from Persea species.

\begin{tabular}{|c|c|c|c|c|}
\hline Compound Name and Synonyms & Source & $\begin{array}{l}\text { Extracts of Different Parts } \\
\text { Used }\end{array}$ & Biological Significance & Reference \\
\hline \multicolumn{5}{|c|}{ Fatty alcohols } \\
\hline $\begin{array}{c}\text { (2R,4R)-1,2,4-trihydroxyheptadec-16-yne [Avocadyne] } \\
\text { 1,2,4-trihydroxyheptadec-16-ene } \\
\text { 2,4-methylene-dioxyheptadec-16-ene-1-ol } \\
\text { 1-acetoxy-2,4-dihydroxyheptadec-16-yne } \\
\text { (2R,4R)1,2,4-Nonadecanetriol. } \\
\text { (2R,4R,6E)-6-Nonadecene-1,2,4-triol } \\
\text { (2R,4R,16E)-16-Nonadecene-1,2,4-triol [Avocadenol D] }\end{array}$ & P. americana & Pulp and seeds & $\begin{array}{l}\text { Inhibition of the dengue virus replication. } \\
\text { Cytotoxic, insecticidal, antimycobacterial, } \\
\text { and trypanocidal activity. }\end{array}$ & {$[10-13,21]$} \\
\hline $\begin{array}{l}\text { (Z,Z)-1-Acetoxy-2-hydroxy-4-oxo-heneicosa-12,15-triene } \\
\text { (Z,Z,E)-1-Acetoxy-2-hydroxy-4-oxo-heneicosa-5,12,15-triene } \\
\text { 1,2,4-trihydroxyheptadec-16-ene }\end{array}$ & P. americana & Idioblast cells of pulp & Antifungal activity & [14] \\
\hline $\begin{array}{c}\text { (2R,4R)16-Heptadecene-1,2,4-triol } \\
\text { and the following derivatives: } \\
1,2, \text { or } 4 \text { acetate } \\
(1,2),(1,4) \text { or }(2,4) \text { di acetate } \\
\text { 1-hexadecanolyl derivative (Avocadoin) }\end{array}$ & P. americana & Peel, idioblast cell, and leaves & $\begin{array}{c}\text { Antifungal, cytotoxic, and insecticidal } \\
\text { activity. }\end{array}$ & {$[11,14,15]$} \\
\hline $\begin{array}{l}\text { 2-(isopropyl)-(2E,4E)-16-Heptadecene-1,2,4-triol } \\
\text { 2-(isopropyl), } \\
\text { 1,4-di-acetyl-(2E,4E)-16-Heptadecene-1,2,4-triol } \\
\text { (2E,5E,12Z,15Z) }\end{array}$ & P. gratissima & Leaves & - & [7] \\
\hline $\begin{array}{l}\text { 1-Hydroxy-2,5,12,15-heneicosatetraen-4-one } \\
\text { 1-Hydroxy-2,12,15-heneicosatrien-4-one }\end{array}$ & P. americana & - & - & [7] \\
\hline Acetyl-2-nonanol & P. gratissima & Leaves & - & [7] \\
\hline $\begin{array}{c}\text { Persin } \\
\text { Tetrahydropersin } \\
\text { Isopersin } \\
\text { Tetrahydropersin }\end{array}$ & P. americana & Idioblast oil cells & $\begin{array}{l}\text { Surfactant and emulsifier, nutrient, } \\
\text { membrane stabilizer, energy source, and } \\
\text { energy storage. }\end{array}$ & {$[8,16,17]$} \\
\hline 1-Acetoxy-2-hydroxy-16-heptadecen-4-one & P. americana & Pulp & & [18] \\
\hline Persenone A and B & P. americana & Pulp & $\begin{array}{c}\text { Nitric oxide and superoxide generation } \\
\text { inhibitors. }\end{array}$ & [19] \\
\hline Secosubamolide & P. americana & Bark & Cytotoxic activity & [20] \\
\hline
\end{tabular}


Table 1. Cont.

\begin{tabular}{|c|c|c|c|c|}
\hline Compound Name and Synonyms & Source & $\begin{array}{l}\text { Extracts of Different Parts } \\
\text { Used }\end{array}$ & Biological Significance & Reference \\
\hline \multicolumn{5}{|c|}{ Phenolics } \\
\hline $\begin{array}{c}\text { Gallic acid } \\
\text { 3,4-Dihydroxyphenylacetic acid } \\
\text { 4-Hydroxybenzoic acid } \\
\text { Vanillic acid } \\
\text { p-Coumaric acid } \\
\text { Ferulic acid } \\
\text { Quercetin }\end{array}$ & P. americana & $\begin{array}{l}\text { Pulp oil and varied by ripening } \\
\text { and peeling }\end{array}$ & Antioxidant activity & [28] \\
\hline $\begin{array}{l}(+) \text {-Catechin } \\
(-) \text {-Epicatechin } \\
\text { Neochlorogenic acid } \\
\text { procyanidins }\end{array}$ & P. americana & By-products & Antioxidant and neuroprotective activity. & {$[22]$} \\
\hline \multirow{2}{*}{$\begin{array}{c}\text { Proanthocyanidins B1, B2 and A-type trimer } \\
\text { Tocopherols (Vitamin E) } \\
\alpha \text {-tocopherol } \\
\gamma \text {-tocopherol }\end{array}$} & P. americana & Seeds & Cytotoxic to HaCat cells. & [23] \\
\hline & P. americana & $\begin{array}{l}\text { Pulp and pulp oil varied by } \\
\text { ripening and peeling }\end{array}$ & Antioxidant activity & {$[24,28]$} \\
\hline $\begin{array}{c}\text { (E)-Chlorogenic acid (Caffeylquinic acid, Caffetannic acid, } \\
\text { Helianthic acid, Igasuric acid) }\end{array}$ & P. americana & - & $\begin{array}{l}\text { Antioxidant, antimicrobial (antibacterial } \\
\text { and antiviral) hepatoprotective, } \\
\text { cardioprotective, anti-hypertension, } \\
\text { anti-obesity, anti-inflammatory, } \\
\text { antipyretic, neuroprotective, central } \\
\text { nervous system stimulator. }\end{array}$ & {$[7,25]$} \\
\hline Scopoletin & P. americana & - & Anti-oncogenic and antioxidant activity. & {$[7,26]$} \\
\hline 4-Hydroxycinnamoylputrescine (4-Coumaroylputresine) & P. gratissima & - & $\begin{array}{l}\text { Nutrient, promotes cell multiplication of } \\
\text { tobacco explants. }\end{array}$ & {$[7,27]$} \\
\hline \multicolumn{5}{|c|}{ Carotenoids } \\
\hline $\begin{array}{c}\text { Lutein } \\
\text { zeaxanthin } \\
\beta \text {-cryptoxanthin } \\
\alpha \text {-carotene } \\
\beta \text {-carotene (pro-vitamin A, retinol) }\end{array}$ & P. americana & $\begin{array}{l}\text { Pulp and pulp oil varied by } \\
\text { ripening and peeling }\end{array}$ & $\begin{array}{l}\text { Cytotoxic to prostate cancer cell lines, } \\
\text { antioxidant, reduces the photosensitivity } \\
\text { reactions in erythropoietic } \\
\text { protoporphyria patients. }\end{array}$ & {$[24,28]$} \\
\hline $\begin{array}{l}\text { 10',11'-Didehydro-5,8,11',12'-tetrahydro-10'-apo- } \beta \text {-carotene-3,5,8-triol } \\
\text { 5,8-Epoxy-5,8-dihydro-10'-apo- } \beta, \psi \text {-carotene-3,10'-diol }\end{array}$ & P. americana & Pulp & \multirow{2}{*}{$\begin{array}{l}\text { Surfactant and emulsifier, nutrient, } \\
\text { membrane stabilizer, energy source and } \\
\text { energy storage. }\end{array}$} & {$[8,29]$} \\
\hline$\alpha$-Citraurin (3-Hydroxy-8'-apo- $\varepsilon$-caroten-8'-al) & P. americana & Pulp & & [30] \\
\hline
\end{tabular}


Table 1. Cont.

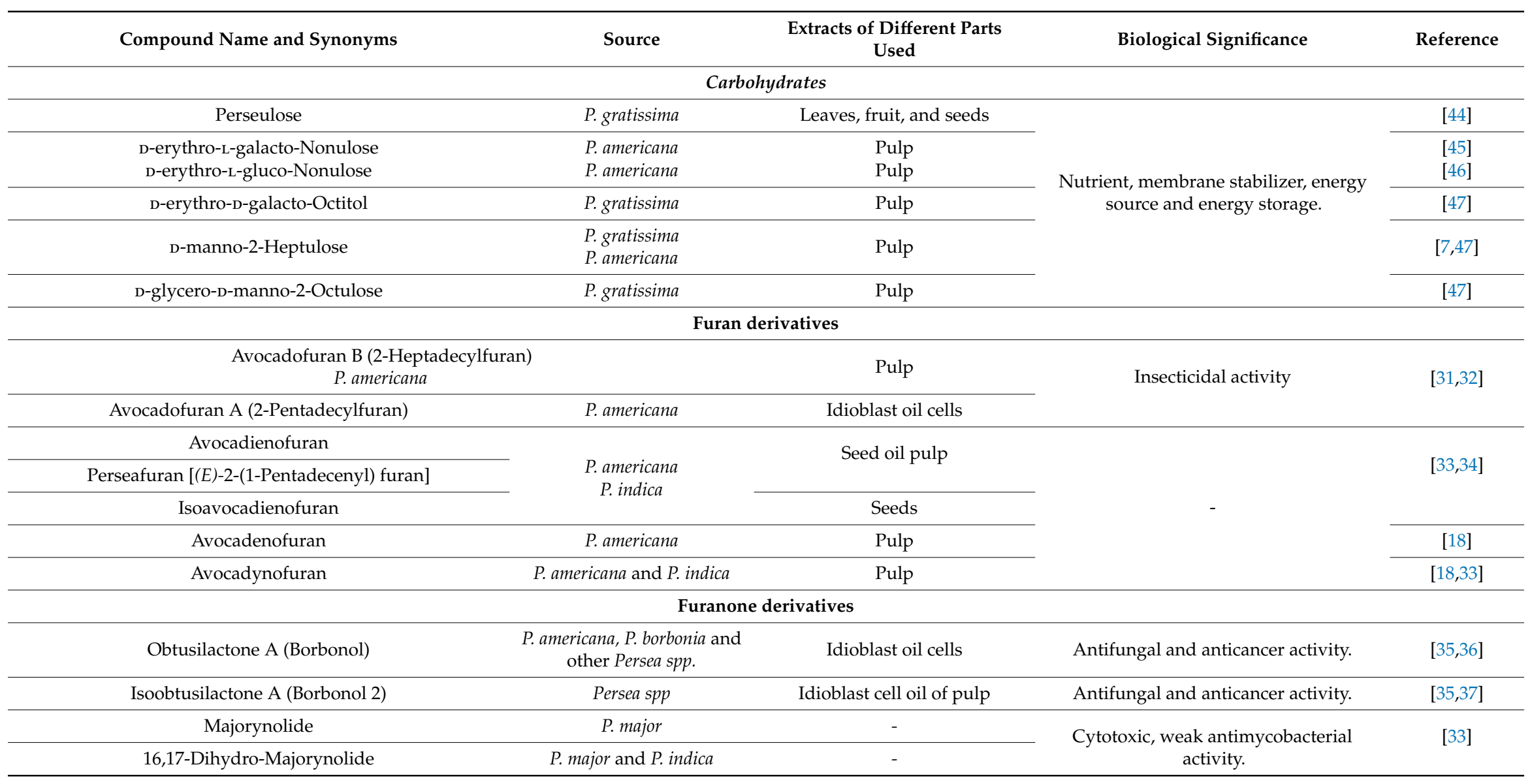


Table 1. Cont.

\begin{tabular}{|c|c|c|c|c|}
\hline Compound Name and Synonyms & Source & $\begin{array}{l}\text { Extracts of Different Parts } \\
\text { Used }\end{array}$ & Biological Significance & Reference \\
\hline \multicolumn{5}{|c|}{ Diterpenoids } \\
\hline $\begin{array}{c}\text { Perseanol } \\
\text { Vignaticol } \\
\text { Indicol } \\
\end{array}$ & P. indica & Branches & Insecticidal and antifeedant activity. & {$[39,40]$} \\
\hline $\begin{array}{c}\text { Ryanodol } \\
\text { 2,3-DidehydrocinnzeylanoneAnhydrocinnzeylanoneGarajonone }\end{array}$ & & & Insecticidal and toxic to mice. & [41-43] \\
\hline \multicolumn{5}{|c|}{ Norlignans/Neolignans/Lignans } \\
\hline 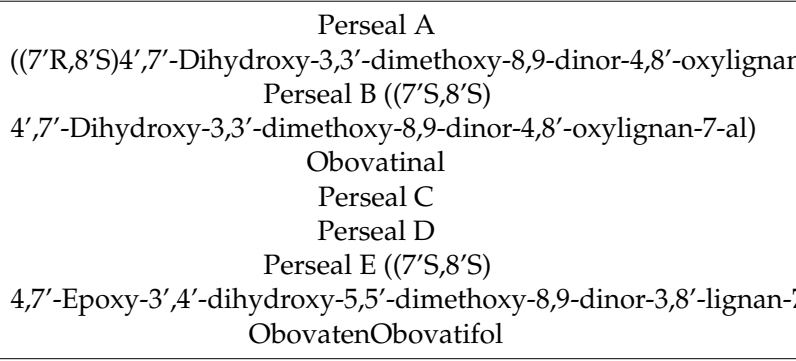 & P. obovatifolia & Branches & Cytotoxic activity & [48-52] \\
\hline Lingueresinol & P. lingue & Bark & - & [53] \\
\hline \multicolumn{5}{|c|}{ Miscellaneous } \\
\hline $\begin{array}{l}\text { (6S,7E,9Z) Abscisic acid-13-Hydroxy, } \\
\text { 13-O- } \beta \text {-D-glucopyranoside }\end{array}$ & P. americana & Seeds & $\begin{array}{l}\text { Derivative of abscisic acid (plant } \\
\text { hormone involved in seed and bud } \\
\text { dormancy). }\end{array}$ & [7] \\
\hline Dimethyl sciadinonate & P. americana & - & Growth inhibitor of silkworm larvae. & {$[7,54]$} \\
\hline $\begin{array}{c}(3 \beta, 5 \alpha, 24 \mathrm{R}) \text { Stigmast-7-en-3-ol; } \\
\text { (Schottenol, 22-Dihydrochondrillasterol, } \\
\text { 22,23-Dihydro- } \alpha \text {-spinasterol, Poriferast-7-en-3-ol) }\end{array}$ & P. americana & Pulp oil & $\begin{array}{l}\text { Protective role by cholesterol metabolism } \\
\text { modulation (liver } \mathrm{x} \text { receptor agonist). }\end{array}$ & [55] \\
\hline Perseapicroside A & P. mexicana & - & - & {$[56]$} \\
\hline Glutathione & P. americana & - & Anticancer and antioxidant activity. & {$[57-59]$} \\
\hline 12-Tridecenal & P. bombycina & Essential oil & - & [60] \\
\hline
\end{tabular}



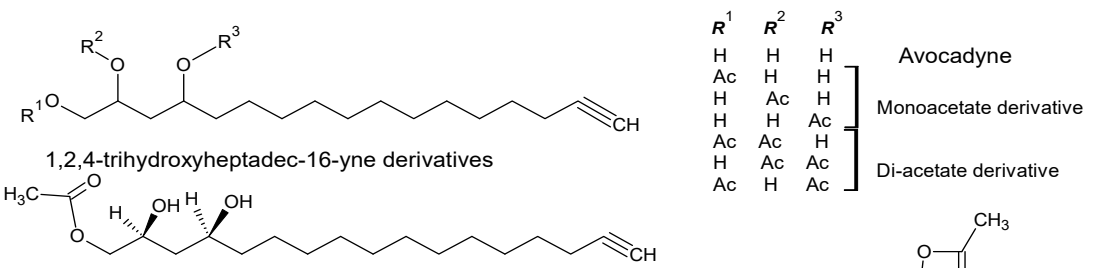

(E,Z,Z)-1-Acetoxy-2,4-dihydroxy- $n$-heptadec-16-yne $\left.\mathrm{H}_{3}, \mathrm{C}, \mathrm{Z}\right)-1-\mathrm{O}$
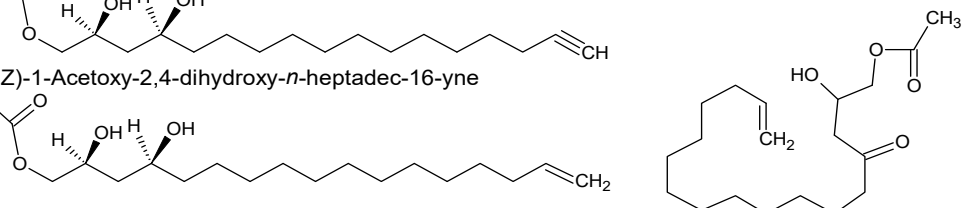

1-Acetoxy-2,4-dihydroxy- $n$-heptadec-16-ene

1-Acetoxy-2-hydroxy-16-heptadecen-4-one<smiles>CC(=O)OC[C@H](O)CC=O</smiles><smiles>CCCCC/C=C\C/C=C\C/C=C/C(C)=O</smiles><smiles>CCCCC/C=C\C/C=C\CCCC(=O)C[C@H](O)COC(C)=O</smiles>

(Z,Z,E)-1-Acetoxy-2-hydroxy-4-oxo-heneicosa-5,12,15-triene

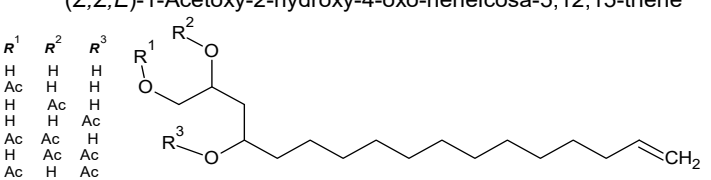

(Z,Z)-1-Acetoxy-2-hydroxy-4-oxo-heneicosa-12,15-triene

$\begin{array}{lll}H & H & H \\ A C & H & H \\ H & A C & H \\ H & H & A C \\ A C & A C & H \\ H & A C & A C \\ A C & H & A C\end{array}$ 1,2,4-trihydroxyheptadec-16-ene derivatives

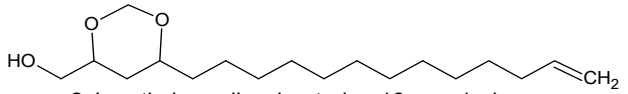

2,4-methylene-dioxyheptadec-16-ene-1-ol.<smiles>CCCCCCCCCCCC/C=C/CC(O)CC(O)CO</smiles>

(2R,4R,6E)-6-nonadecene-1,2,4-triol
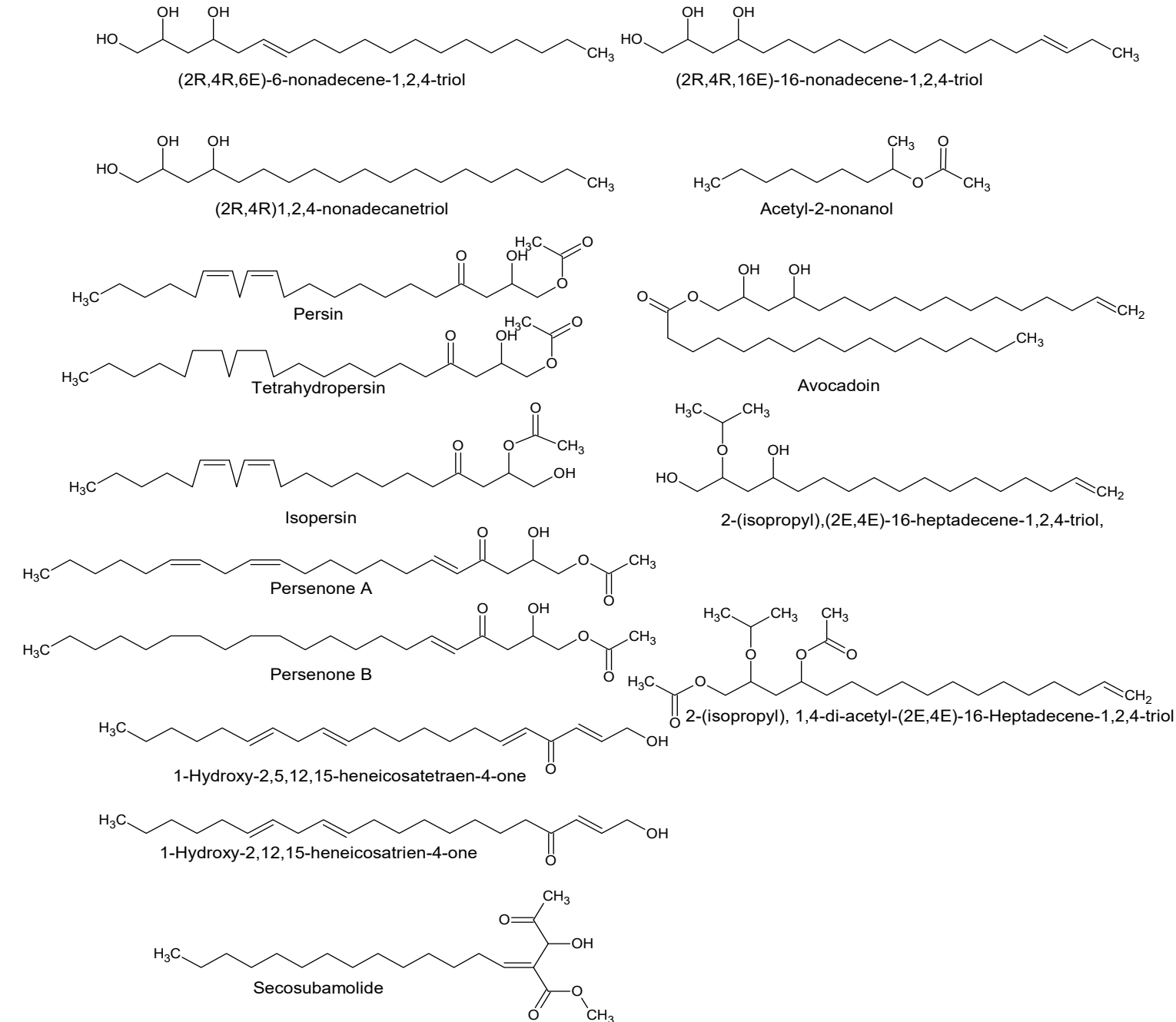

$(2 \mathrm{R}, 4 \mathrm{R}) 1,2,4$-nonadecanetriol

(2R,4R,16E)-16-nonadecene-1,2,4-triol

Figure 1. Fatty alcohols isolated from avocado. 


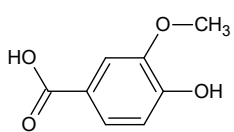<smiles>O=C(O)c1ccc(O)cc1</smiles><smiles>O=C(O)c1cc(O)c(O)c(O)c1</smiles>

4-hydroxybenzoic acid $\mathrm{HO}$<smiles>O=C(O)Cc1ccc(O)cc1</smiles><smiles>O=C(O)/C=C/c1ccc(O)cc1</smiles>

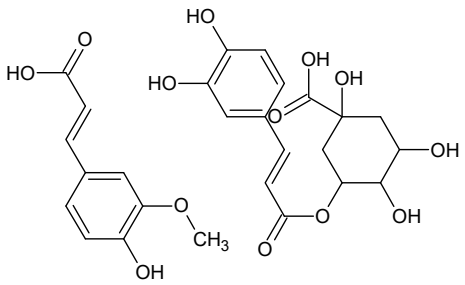

p-coumaric acid

Ferulic acid Neochlorogenic acid

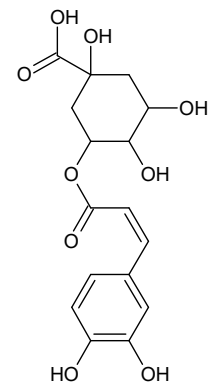
acid<smiles>Oc1cc(O)c2c(c1)O[C@H](c1ccc(O)c(O)c1)C(O)[C@H]2c1c(O)cc(O)c2c1O[C@H](c1ccc(O)c(O)c1)[C@H](O)C2</smiles><smiles>Oc1cc(O)c2c(c1)O[C@H](c1ccc(O)c(O)c1)C(O)C2c1c(O)cc(O)c2c1O[C@H](c1ccc(O)c(O)c1)[C@H](O)C2</smiles>

Proanthocyanidins B2<smiles>COc1c(O)cc(C2Oc3c(c(O)cc(O)c3C3c4c(O)cc(O)cc4OC(c4ccc(O)cc4)C3O)CC2O)cc1O</smiles>

Proanthocyanidins A1

Proanthocyanidins B1

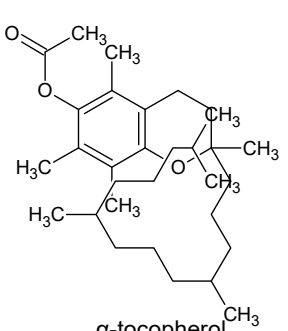<smiles>Cc1c(O)cc2c(c1C)OC1(C(C)C)CCCC(C)CCCC(C)(C)CC2CC1</smiles>

y-tocopherol

$$
\mathrm{OH}
$$<smiles>CCOCc1c(O)cccc1O[C@@H](c1ccc(O)c(O)c1)[C@H](O)CO</smiles>

(+)- Catechin
(-)- Epicatechin<smiles>Cc1ccc(O)c(O)c1</smiles>

$\mathrm{OH}$

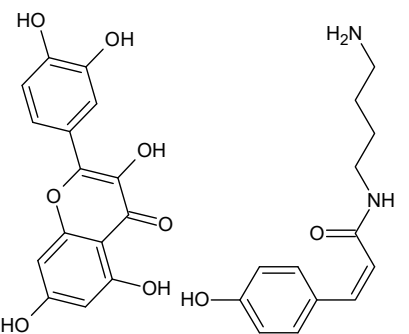

Quercetin

Figure 2. Phenolic compounds isolated from avocado. 


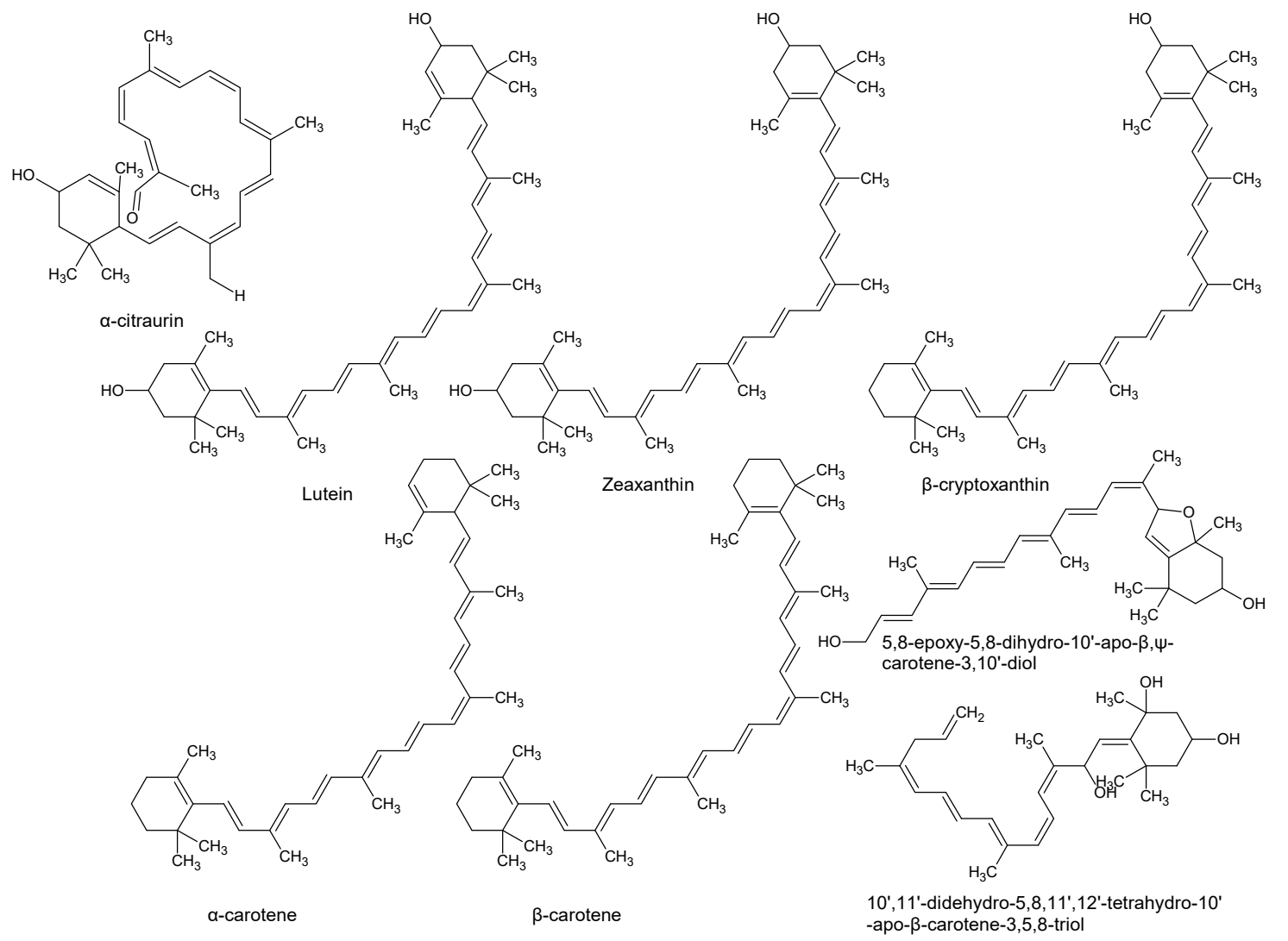

Figure 3. Carotenoids isolated from avocado.<smiles>OCC(O)C(O)C(O)C(O)C(O)CO</smiles><smiles>O=C(CO)C(O)C(O)C(O)C(O)C(O)C(O)C(O)CO</smiles>

Persitol D-erythro-L-galacto-nonulose D-erythro-L-gluco-nonulose<smiles>OCC(O)C(O)C(O)C(O)C(O)C(O)CO</smiles><smiles>O=C(CO)C(O)C(O)C(O)C(O)CO</smiles><smiles>O=C(CO)C(O)C(O)C(O)C(O)C(O)CO</smiles>

D-erythro-D-galacto-octitol

Manno-2-heptulose

D-glycero-D-manno-2-octulose

Figure 4. Sugars and sugar alcohol isolated from avocado. 

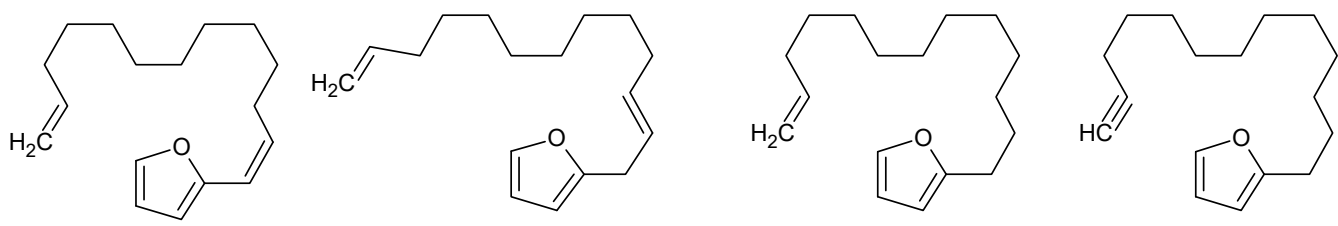

Avocadienofuran

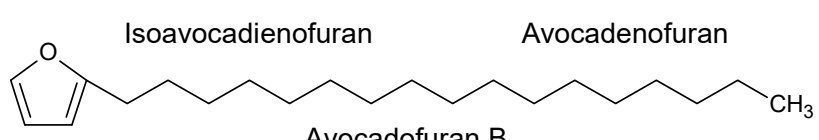

Avocadynofuran

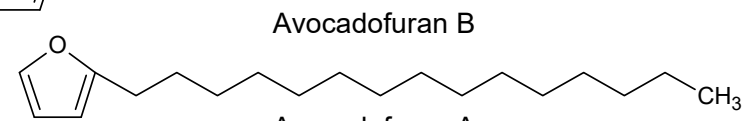

Avocadofuran $\mathrm{A}$
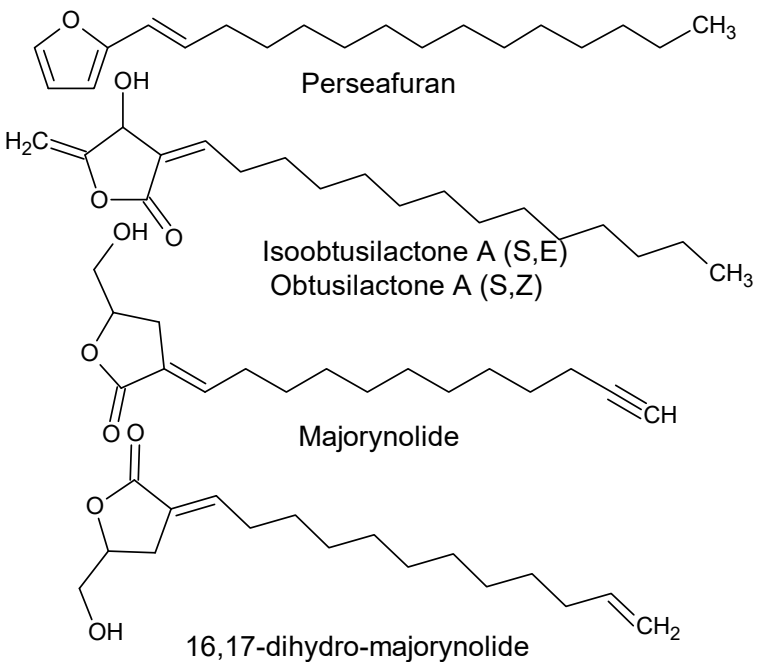

Figure 5. Furan and furanone derivatives isolated from avocado. 


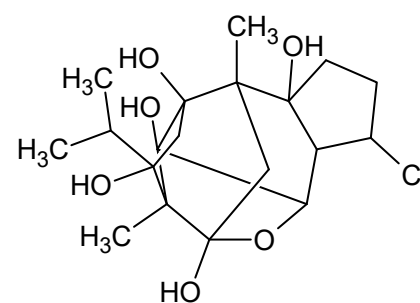

Vignaticol

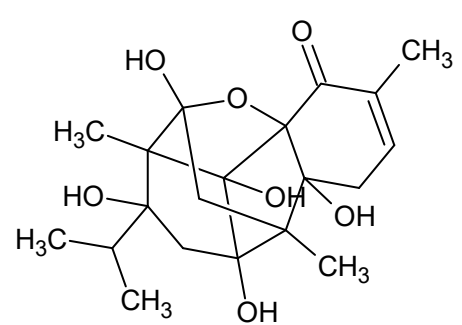

2,3-didehydrocinnzeylanone

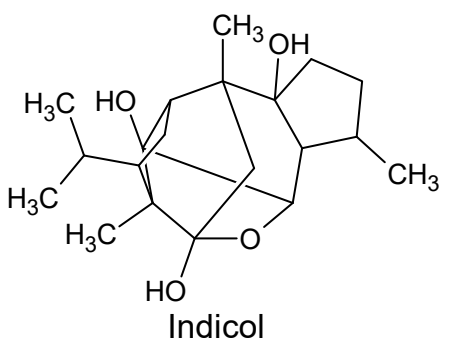

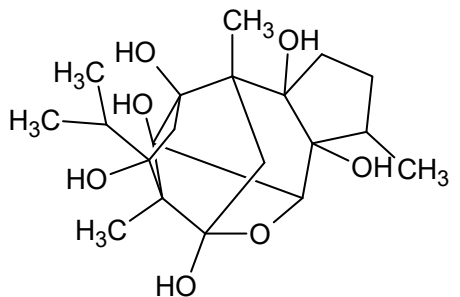

Perseanol<smiles>CC1=C(C(C)C)CC2(O)C(O)C13OC(=O)CC2(C)C3(O)O</smiles>

Anhydrocinnzeylanone

Figure 6. Diterpenoids isolated from avocado. 
<smiles>C/C=C/c1cc(OC)c2c(c1)C(C)C(c1cc(O)c(O)c(OC)c1)O2</smiles>

Perseal E

Lingueresinol<smiles>COc1cc(-c2oc3c(OC)cc(C=O)cc3c2C)cc(OC)c1O</smiles>

Figure 7. Norlignans, neolignans, and lignans isolated from avocado.<smiles>CC(C=CC1(O)C(C)=CC(=O)CC1(C)COC1OC(CO)C(O)C(O)C1O)=CC(=O)O</smiles>

Abscisic acid-13-hydroxy,

13-O- $\beta$-D-glucopyranoside; (6S,7E,9Z)<smiles>C=C1CCC2C(C)(C(=O)OC)CCCC2(C(=O)OC)C1CC(=O)c1ccoc1</smiles>

Dimethyl sciadinonate<smiles>CCCCCOCCOCCO</smiles>

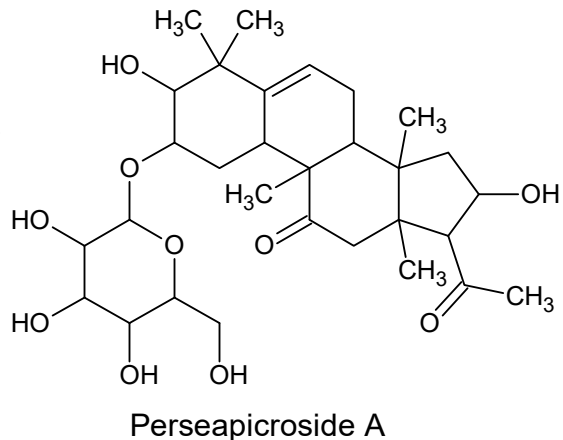

Perseapicroside A<smiles>[Z12]C(C)(O)C(=O)C(N)CCC(=O)N[C@H](CS)C(=O)NCC(=O)O</smiles>

Glutathione

Figure 8. Miscellaneous compounds isolated from avocado. 


\subsection{Nutritional Composition of P. americana}

Avocados have been recognized for their high nutritional value and therapeutic importance for centuries. The nutritional composition of avocado is shown in Table 2 according to the United States Department of Agriculture (USDA) [61]. A whole avocado is reported to contain 140 to $228 \mathrm{kcal}$ ( $~ 585-1000 \mathrm{~kJ})$ of energy depending on the size and variety [62]. The variety, grade of ripening, climate, the composition of the soil, and fertilizers are the major factors that largely influence the nutritional profiles of avocados [63].

Table 2. Pulp composition of Persea americana (avocado) [61].

\begin{tabular}{|c|c|c|c|c|}
\hline Nutritional Composition & Unit & Value Per $100 \mathrm{~g}$ & 1 Fruit $136 \mathrm{~g}$ & 1 Serving $30 \mathrm{~g}$ \\
\hline \multicolumn{5}{|c|}{ 1. Proximate } \\
\hline Water & $\mathrm{g}$ & 72.3 & 98.4 & 21.7 \\
\hline Energy & kcal & 167 & 227 & 50 \\
\hline $\begin{array}{l}\text { Energy (insoluble fiber } \\
\text { adjusted) }\end{array}$ & kcal & 148 & 201 & 44 \\
\hline Protein & $g$ & 1.96 & 2.67 & 0.59 \\
\hline Total lipid (fat) & $\mathrm{g}$ & 15.41 & 21 & 4.62 \\
\hline Ash & $\mathrm{g}$ & 1.66 & 2.26 & 0.5 \\
\hline Carbohydrate & g & 8.64 & 11.8 & 2.59 \\
\hline Fiber & g & 6.8 & 9.2 & 2 \\
\hline Sugars & $\mathrm{g}$ & 0.3 & 0.41 & 0.09 \\
\hline Starch & $\mathrm{g}$ & 0.11 & 0.15 & 0.03 \\
\hline \multicolumn{5}{|c|}{ 2. Minerals } \\
\hline Calcium & $\mathrm{mg}$ & 13 & 18 & 4 \\
\hline Iron & $\mathrm{mg}$ & 0.61 & 0.83 & 0.18 \\
\hline Magnesium & $\mathrm{mg}$ & 29 & 39 & 9 \\
\hline Phosphorus & $\mathrm{mg}$ & 54 & 73 & 16 \\
\hline Potassium & $\mathrm{mg}$ & 507 & 690 & 152 \\
\hline Sodium & $\mathrm{mg}$ & 8 & 11 & 2 \\
\hline Zinc & $\mathrm{mg}$ & 0.68 & 0.92 & 0.2 \\
\hline Copper & $\mathrm{mg}$ & 0.17 & 0.23 & 0.05 \\
\hline Manganese & $\mathrm{mg}$ & 0.15 & 0.2 & 0.05 \\
\hline Selenium & ug & 0.4 & 0.5 & 0.1 \\
\hline \multicolumn{5}{|c|}{ 3. Vitamins and Phytochemicals } \\
\hline Vitamin C & $\mathrm{mg}$ & 8.8 & 12 & 2.6 \\
\hline Thiamine & $\mathrm{mg}$ & 0.08 & 0.1 & 0.02 \\
\hline Riboflavin & $\mathrm{mg}$ & 0.14 & 0.19 & 0.04 \\
\hline Niacin & $\mathrm{mg}$ & 1.91 & 2.6 & 0.57 \\
\hline Pantothenic acid & $\mathrm{mg}$ & 1.46 & 2 & 0.44 \\
\hline Vitamin B-6 & $\mathrm{mg}$ & 0.29 & 0.39 & 0.09 \\
\hline $\begin{array}{l}\text { Folate, dietary folate } \\
\text { equivalents }\end{array}$ & $\mu g$ & 89 & 121 & 27 \\
\hline Choline total & $\mathrm{mg}$ & 14.2 & 19.3 & 4.3 \\
\hline Betaine & $\mathrm{mg}$ & 0.7 & 1 & 0.2 \\
\hline Vitamin B-12 & $\mu g$ & 0 & 0 & 0 \\
\hline Vitamin A & $\mu g$ & 7 & 10 & 2 \\
\hline$\beta$-Carotene & $\mu g$ & 63 & 86 & 19 \\
\hline$\alpha$-Carotene & $\mu g$ & 24 & 33 & 7 \\
\hline$\beta$-Cryptoxanthin & $\mu g$ & 27 & 37 & 8 \\
\hline Lutein + zeaxanthin & $\mu \mathrm{g}$ & 271 & 369 & 81 \\
\hline Vitamin E ( $\alpha$-tocopherol) & $\mathrm{mg}$ & 1.97 & 2.68 & 0.59 \\
\hline Tocopherol $\beta$ & $\mathrm{mg}$ & 0.04 & 0.05 & 0.01 \\
\hline Tocopherol $\gamma$ & $\mathrm{mg}$ & 0.32 & 0.44 & 0.1 \\
\hline Tocopherol $\delta$ & $\mathrm{mg}$ & 0.02 & 0.03 & 0.01 \\
\hline Vitamin K1 (phylloquinone) & $\mu \mathrm{g}$ & 21 & 28.6 & 6.3 \\
\hline
\end{tabular}


Table 2. Cont.

\begin{tabular}{|c|c|c|c|c|}
\hline Nutritional Composition & Unit & Value Per $100 \mathrm{~g}$ & 1 Fruit $136 \mathrm{~g}$ & 1 Serving $30 \mathrm{~g}$ \\
\hline \multicolumn{5}{|c|}{ 4. Lipids } \\
\hline $\begin{array}{l}\text { Fatty acids, total } \\
\text { monounsaturated }\end{array}$ & $\mathrm{g}$ & 9.799 & 13.3 & 2.94 \\
\hline $16: 1$ & $\mathrm{~g}$ & 0.698 & & \\
\hline $17: 1$ & $\mathrm{~g}$ & 0.01 & & \\
\hline $18: 1$ & $\mathrm{~g}$ & 9.066 & & \\
\hline $20: 1$ & $\mathrm{~g}$ & 0.025 & & \\
\hline Fatty acids, total saturated & $\mathrm{g}$ & 2.126 & 2.9 & 0.64 \\
\hline $8: 0$ & $\mathrm{~g}$ & 0.001 & & \\
\hline $16: 0$ & $\mathrm{~g}$ & 2.075 & & \\
\hline $18: 0$ & $\mathrm{~g}$ & 0.049 & & \\
\hline $\begin{array}{l}\text { Fatty acids, total } \\
\text { polyunsaturated }\end{array}$ & $\mathrm{g}$ & 1.816 & 2.47 & 0.55 \\
\hline $18: 2$ & $\mathrm{~g}$ & 1.674 & & \\
\hline $18: 3$ & $\mathrm{~g}$ & 0.125 & & \\
\hline $18: 3 n-3$ c,c,c (ALA) & $\mathrm{g}$ & 0.111 & & \\
\hline $18: 3$ n- 6 c,c,c & $\mathrm{g}$ & 0.015 & & \\
\hline $20: 3$ & $\mathrm{~g}$ & 0.016 & & \\
\hline Cholesterol & $\mathrm{mg}$ & 0 & 0 & 0 \\
\hline Stigmasterol & $\mathrm{mg}$ & 2 & 3 & 1 \\
\hline Campesterol & $\mathrm{mg}$ & 5 & 7 & 2 \\
\hline$\beta$-sitosterol & $\mathrm{mg}$ & 76 & 103 & 23 \\
\hline
\end{tabular}

Fiber constitutes most of its carbohydrate content ( $\sim 9 \mathrm{~g}$ of fiber and $12 \mathrm{~g}$ of carbohydrate per avocado) (Table 2) and can reach up to $13.5 \mathrm{~g}$ in larger avocados. Higher quantities of insoluble and soluble fibers ( $70 \%$ and $30 \%$, respectively) are found in the pulp [3]. A single serving can provide about $2 \mathrm{~g}$ protein and $2 \mathrm{~g}$ of fiber with a glycemic index of $1 \pm 1$ [64]. A high-fiber diet is often linked with a healthy digestive system. Moreover, it may help lower blood cholesterol levels and prevent constipation by improving bowel movement. In particular, avocados have been shown to improve the microflora of the intestines by working as a prebiotic [65]. In addition to fat, avocados are rich in protein (highest among fruits), sugars including sucrose and 7-carbon carbohydrates (D-mannoheptulose), antioxidants, pigments, tannins, and phytoestrogens [66].

Fat contributes to most of the calories in an avocado. A 1000-kJ portion of avocado contains about $25 \mathrm{~g}$ of fat, most of which are healthier monounsaturated fatty acids (MUFA) [64]. The lipid content in avocados is higher than in other fruits. Most lipids found in avocados are polar lipids (glycolipids and phospholipids), which play a fundamental role in various cellular processes such as the functioning of the cell membranes as second messengers [67]. These lipids are also used to make emulsions of water and lipids, and have a wide variety of applications in food, pharmaceuticals, and cosmetics industries [68]. Compared to other vegetable oils, avocado oils are high in MUFA (oleic and palmitoleic acids) and low in polyunsaturated fatty acids (linoleic acid and linolenic acid) [3]. Oleic acid is the principal fatty acid in avocado, comprising $45 \%$ of its total fatty acids [69], and during the ripening process, palmitic acid content decreases and oleic acid content increases [70]. In terms of its total fat content and fatty acid composition, avocado oil is considered to be similar to olive oil [71]. Other fatty acids present include palmitic and palmitoleic acids with smaller [64] amounts of myristic, stearic, cinolenic, and arachidonic acids [62]. However, the compositions of these fatty acids largely depend on the cultivars, stage of maturity, and part of the fruit and geographic location of plant growth [62]. Avocado spread instead of other fatty alternatives such as butter, cream cheese, and mayonnaise on sandwiches can help significantly reduce the intake of calories, saturated fat, sodium, and cholesterol.

Avocados are notable for their potassium content $(>500 \mathrm{mg} / 100 \mathrm{~g}$ of fresh weight), and it provides $60 \%$ more than an equal serving of banana [72]. Potassium intake helps to maintain cardiovascular health and muscle function by regulating the blood pressure through the modulation of liquid retention 
in the body [65]. In addition, potassium regulates the electrolyte balance in the body, which is important for the conduction of electrical signals in the heart (i.e., a steady, healthy heart rate) [65]. The high potassium and low sodium contents in the diet are shown to protect against cardiovascular diseases [3]. Moreover, avocados contain a number of other minerals, including phosphorus, magnesium, calcium, sodium, iron, and zinc ( $<1 \mathrm{mg} / \mathrm{g}$ of fresh weight) [73].

Vitamins such as $\beta$-carotene, tocopherol, retinol, ascorbic acid, thiamine, riboflavin, niacin, pyridoxine, and folic acid are also abundantly found in avocado, which are of great importance for overall health and well-being (Table 2) [62,74]. Carotenoids, including lutein, zeaxanthin, and $\alpha$ - and $\beta$-carotene found in the pulp of the avocado are potent free radical scavengers $[65,74]$. The lutein content of avocado is higher than any other fruit, which comprises about $70 \%$ of its total carotenoid content [65]. The color of avocado pulp is predominantly attributed to the higher content of xanthophylls (lutein and zeaxanthin). Seasonal variations in the phytochemical profile of avocado especially carotenoids, tocopherol, and fatty acid content have also been reported [65]. Due to their fat-soluble nature, these bioactive compounds have been shown to promote vascular health [65]. Xanthophylls suppress the damage of blood vessels by decreasing the amount of oxidized low-density lipoproteins (LDL) [75]. Additionally, lutein and zeaxanthin have been reported to slow down the progression of age-related macular degeneration, cataracts, and cartilage deterioration [74,76]. Carotenoids in general were demonstrated to protect the skin from ultraviolet radiation-associated oxidation and inflammation [62]. Furthermore, a $68 \mathrm{~g}$ serving of Hass avocado contains about $57 \mathrm{mg}$ of phytosterols, which is significantly higher compared to other fruits (about $3 \mathrm{mg}$ per serving) [65]. Avocado phytosterols have been reported to reduce the risks of coronary heart disease [65]. The American Heart Association recommends the consumption of 2-3 g of sterols and stanols per day to promote heart health $[65,77]$. They are the plant analogues of cholesterol and can be classified into three major groups consisting of $\beta$-sitosterol, campesterol, and stigmasterol [78]. The most abundant phytosterol present in avocado is $\beta$-sitosterol $(76.4 \mathrm{mg} / 100 \mathrm{~g})$, followed by campesterol $(5.1 \mathrm{mg} / 100$ g) and stigmasterol ( $<3 \mathrm{mg} / 100 \mathrm{~g}$ ) [79]. In addition to its cholesterol-lowering activity, $\beta$-sitosterol has been demonstrated to inhibit the production of carcinogenic compounds, alleviate symptoms associated with benign prostatic hyperplasia, and strengthen the immune system [79]. In summary, these compounds have been hypothesized to work in conjunction in the prevention of oxidative stress and age-related degenerative diseases [80].

\subsection{Antioxidant Properties of P. americana}

Considering the health risks associated with synthetic antioxidants, the extraction, isolation, and identification of antioxidants from natural sources have become primary research focuses of the food, nutraceutical, and pharmaceutical industries in the recent years [81-83]. Annually, over three million tons of avocados are produced worldwide, with only the pulp being used, while the seeds and peel are discarded [2]. Waste utilization by exploiting the phytochemical content of avocado by-products such as seeds and peel will add more value to the avocado industry and may lead to novel product development [84]. Table 3 represents the studies currently available in the literature emphasizing the role of P. Americana plant as the source of potent antioxidants. Different parts of the plant, including the leaf, fruit pulp, peel, and seed have been widely studied for their antioxidant properties using conventional spectroscopic assays such as 2,2'-azino-bis (3-ethylbenzothiazoline-6-sulfonic acid diammonium salt (ABTS), 2,2-diphenyl-1-picrylhydrazyl (DPPH), oxygen radical absorbance capacity (ORAC), cupric-reducing antioxidant capacity (CUPRAC), and ferric-reducing ability of plasma (FRAP) as well as more sensitive analytical techniques including high-performance liquid chromatography (HPLC), high-performance liquid chromatography-mass spectrometry (HPLC-MS), gas chromatography-mass spectrometry (GC-MS) and gas chromatography-flame ionization detector (GC-FID). Hass is the most explored avocado variety in terms of its antioxidant properties, which can perhaps be attributed to the popularity and easier availability of this variety. It is evident from the studies performed so far that phenolic compounds (including phenolic and hydroxycinnamic acids, flavonoids, and condensed 
tannins), carotenoids, $\alpha, \beta, \gamma$, and $\delta$-tocopherols, acetogenins, monounsaturated and polyunsaturated fatty acids are the key antioxidants found in avocado. Moreover, most of these studies have reported significant positive correlations between the phenolic compounds and antioxidant capacity of avocado extracts [84-88]. Phenolic compounds found in avocado were shown to reduce oxidation, inflammation, and platelet aggregation [65]. Several studies have reported that different parts of the avocado plants contain potent phenolic antioxidants such as chlorogenic-, quinic-, succinic-, pantothenic-, abscisic-, ferulic-, gallic-, sinapinic-, p-coumaric-, gentisic-, protocatechuic-, 4-hydroxybenzoic-, and benzoicacids, quercetin, quercetin-3-glucoside, quercetin-3-rhamnoside, vanillin, $p$-coumaroyl-D-glucose, catechins, (-)-epicatechin, and procyanidins (Table 3) [2,28,84,89-97]. Among the different parts of avocado investigated in several studies, leaf, peel, and seed extracts have shown consistently greater antioxidant capacity compared to that of the pulp [84,91,94,96-106]. Due to the presence of higher catechin, epicatechin, leucoanthocyanidin, triterpenes, furoic acid, and proanthocyanidin contents, avocado seed extracts have been reported to display greater antioxidant capacity [62,74]. Additionally, the ripening process was also shown to influence the phenolic contents of different parts of the avocado plant [96,107,108]. For example, a study by López-Cobo et al. [96] found a higher content of phenolics in the pulp and seed extracts of overripe avocados compared to their optimally ripe counterparts. It was hypothesized that the increase in the total phenolic content in the overripe fruit was mediated by higher phenylalanine ammonia-lyase activity associated with the ripening process [96]. They also observed an increased concentration of procyanidins in the overripe parts of the avocado, which was probably a result of the hydrolysis of complex tannins after ripening. Avocado peel, seed, and leaf, as the major by-products of the avocado industry, have been demonstrated as rich sources of polyphenolics and antioxidants. More studies developing robust, green, and economical extraction techniques are fundamental to obtain greater yields of potent antioxidants. In vivo and clinical studies to understand the bioavailability of these antioxidants and their potential toxicity are also crucial. 
Table 3. Antioxidant properties of Persea Americana (avocado).

\begin{tabular}{|c|c|c|c|c|c|c|}
\hline Variety & Part Studied & Types of Extract & Detection Assays & Major Findings & Type of Antioxidants & References \\
\hline Hass & Pulp and peel + pulp & Expeller pressed oils & ABTS and HPLC-PDA & $\begin{array}{l}\text { Higher antioxidant capacity, } \\
\alpha \text {-tocopherol and } \beta \text {-carotene } \\
\text { content were observed in oils } \\
\text { from the unpeeled } \\
\text { microwave-dried pulp of ripe } \\
\text { and unripe avocado. }\end{array}$ & $\begin{array}{l}\text { Oils from the pulp of ripe } \\
\text { unpeeled microwave-dried } \\
\text { avocado had significantly } \\
\text { greater phenolic acid and } \\
\text { quercetin contents. }\end{array}$ & [28] \\
\hline Hass & Peel & $\begin{array}{l}50 \%(v / v) \text { ethanol } \\
\text { using accelerated } \\
\text { solvent extraction }\end{array}$ & $\begin{array}{l}\text { HPLC coupled to } \\
\text { ultra-high-definition } \\
\text { accurate-mass-QTOF }\end{array}$ & $\begin{array}{l}\text { Sixty-one compounds } \\
\text { belonging to } 11 \text { families were } \\
\text { identified. }\end{array}$ & $\begin{array}{l}\text { Procyanidins, flavonols, } \\
\text { hydroxybenzoic, and } \\
\text { hydroxycinnamic acids. }\end{array}$ & [90] \\
\hline Hass & Seeds and seed coat & $\begin{array}{l}\text { Accelerated solvent } \\
\text { extraction }\end{array}$ & $\begin{array}{l}\text { DPPH, TEAC, ORAC, } \\
\text { HPLC-DAD-ESI-QTOF-MS }\end{array}$ & $\begin{array}{l}\text { Significant antioxidant activity } \\
\text { was observed in both seed and } \\
\text { seed coat extracts. A total of } 84 \\
\text { compounds were identified, } \\
\text { among which } 45 \text { were phenolic } \\
\text { compounds. }\end{array}$ & $\begin{array}{l}\text { Condensed tannins, phenolic } \\
\text { acids, and flavonoids. }\end{array}$ & [91] \\
\hline Hass & Pulp & $\begin{array}{l}\text { Oil extracted with or } \\
\text { without ultrasound }\end{array}$ & HPLC & $\begin{array}{l}\text { Similar quantities of } \alpha, \beta, \gamma, \\
\text { and } \delta \text {-tocopherols and phenolic } \\
\text { compounds were detected both } \\
\text { with and without ultrasound } \\
\text { extractions. }\end{array}$ & Tocopherols and phenols. & [109] \\
\hline Hass & Seeds & $\begin{array}{l}\text { Methanol and } 50 \% \\
(v / v) \text { ethanol }\end{array}$ & $\begin{array}{l}\text { HPLC, ABTS, FRAP, ORAC } \\
\text { and methoxy radical } \\
\text { scavenging activity by EPR }\end{array}$ & $\begin{array}{c}50 \%(v / v) \text { ethanol extract } \\
\text { displayed greater antioxidant } \\
\text { capacity in the ORAC, FRAP, } \\
\text { and ABTS assays. }\end{array}$ & $\begin{array}{c}\text { Chlorogenic acid, } \\
\text { (-)-epicatechin, catechins and } \\
\text { procyanidins. }\end{array}$ & [2] \\
\hline Hass & Peel and seeds & Aqueous extract & ORAC & $\begin{array}{l}\text { Peel extract showed higher } \\
\text { antioxidant capacity than seed } \\
\text { extract. }\end{array}$ & $\begin{array}{l}\text { Epicatechin and chlorogenic } \\
\text { acid were found in both } \\
\text { extracts. }\end{array}$ & [101] \\
\hline Hass & Pulp, peel, and seeds & $\begin{array}{l}\text { Hexane to eliminate } \\
\text { lipids and } 80 \% \\
\text { methanol for phenolic } \\
\text { extraction }\end{array}$ & HPLC-DAD-ESI-QTOF-MS & $\begin{array}{l}\text { Higher concentrations of } \\
\text { phenolic compounds were } \\
\text { detected in the pulp and seed } \\
\text { extract of overripe than in pulp } \\
\text { and seed of optimally ripe fruit. } \\
\text { The concentration of } \\
\text { procyanidins increased after } \\
\text { ripening. }\end{array}$ & $\begin{array}{l}\text { Nine compounds in pulp, three } \\
\text { in peel and three in seed. } \\
\text { Procyanidins to degree of } \\
\text { polymerization } 2 \text { to } 6 \text {, and } 13 \\
\text { were identified and quantified. }\end{array}$ & [96] \\
\hline
\end{tabular}


Table 3. Cont

\begin{tabular}{|c|c|c|c|c|c|c|}
\hline Variety & Part Studied & Types of Extract & Detection Assays & Major Findings & Type of Antioxidants & References \\
\hline Hass & Peel, pulp, and seeds & $\begin{array}{l}\text { Ultrasonic extraction } \\
\text { with } 80 \%(v / v) \text { ethanol }\end{array}$ & $\mathrm{DPPH}$, and ABTS & $\begin{array}{l}\text { Seed and peel extracts } \\
\text { exhibited greater antioxidant } \\
\text { values and phenolic content } \\
\text { than the pulp extract. }\end{array}$ & - & [102] \\
\hline Hass & Peel, pulp, and seeds & $\begin{array}{l}\text { Different solvents for } \\
\text { different assays }\end{array}$ & DPPH and spectroscopic & $\begin{array}{l}\text { All extracts exhibited } \\
\text { significant antioxidant capacity. } \\
\text { The seed extract had the } \\
\text { greatest antioxidant activity, } \\
\text { total phenolic content, and } \\
\text { flavonoids compared to that of } \\
\text { peel and pulp. }\end{array}$ & $\begin{array}{c}\text { Carotenoids, phenolic } \\
\text { compounds, flavonoids, } \\
\text { vitamin c and tocopheryl } \\
\text { acetate were detected in all } \\
\text { extracts. }\end{array}$ & [106] \\
\hline Hass & Pulp & $\begin{array}{l}\text { Aqueous and } \\
\text { ethanolic }\end{array}$ & FRAP and DPPH & $\begin{array}{l}\text { Harvesting seasons affected the } \\
\text { antioxidant capacity. }\end{array}$ & $\begin{array}{l}\text { Positive correlations between } \\
\text { FRAP and total phenolics, } \\
\text { DPPH and total phenolics }\end{array}$ & [85] \\
\hline Hass & Pulp & $\begin{array}{l}\text { Hydrophilic and } \\
\text { lipophilic extracts }\end{array}$ & DPPH, TEAC and ORAC & $\begin{array}{l}\text { Higher antioxidant capacity } \\
\text { values were obtained from } \\
\text { lipophilic extracts compared to } \\
\text { hydrophilic extracts. }\end{array}$ & $\begin{array}{l}\text { A positive correlation was } \\
\text { observed between } \\
\text { DPPH/TEAC assays with } \\
\text { palmitoleic, oleic, linoleic, } \\
\alpha \text {-linolenic acids. }\end{array}$ & [108] \\
\hline Hass & Pulp & Tetrahydrofuran & $\mathrm{DPPH}$ & Low antioxidant activity. & $\begin{array}{l}\text { A slight positive correlation } \\
\text { against stearic acid content. }\end{array}$ & [111] \\
\hline Hass & $\begin{array}{l}\text { Leaves, pulp, peel, } \\
\text { and seeds }\end{array}$ & Freeze-dried samples & $\begin{array}{l}\text { FRAP, } \\
\text { 4-dinitrophenylhydrazine and } \\
\text { HPLC }\end{array}$ & $\begin{array}{l}\text { The leaf, peel, and seed extracts } \\
\text { had greater antioxidant } \\
\text { capacity than that the pulp } \\
\text { extracts. C7 sugars such as } \\
\text { mannoheptulose and perseitol } \\
\text { contributed to the antioxidant } \\
\text { capacity of the pulp. }\end{array}$ & $\begin{array}{l}\text { Vitamin C, anthocyanin, and } \\
\text { C7 sugars. }\end{array}$ & [100] \\
\hline
\end{tabular}


Table 3. Cont

\begin{tabular}{|c|c|c|c|c|c|c|}
\hline Variety & Part Studied & Types of Extract & Detection Assays & Major Findings & Type of Antioxidants & References \\
\hline $\begin{array}{l}\text { Hass and } \\
\text { Fuerte }\end{array}$ & Peel and seeds & $\begin{array}{l}80 \%(v / v) \text { ethanol with } \\
\text { ultrasonic extraction }\end{array}$ & $\begin{array}{c}\text { ABTS, DPPH, FRAP, and } \\
\text { HPLC-ABTS }\end{array}$ & $\begin{array}{l}\text { Peel extracts of both varieties } \\
\text { displayed higher antioxidant } \\
\text { capacity in the ABTS and FRAP } \\
\text { assays compared to their seed } \\
\text { extracts, whereas in the DPPH } \\
\text { assay, seed extracts showed } \\
\text { greater antioxidant activity. }\end{array}$ & $\begin{array}{c}\text { Peel: procyanidin B2 and } \\
\text { epicatechin } \\
\text { Seed: } \\
\text { trans-5-O-caffeoyl-D-quinic } \\
\text { acid, procyanidin B1, catechin, } \\
\text { and epicatechin. }\end{array}$ & [97] \\
\hline $\begin{array}{l}\text { Hass and } \\
\text { Fuerte }\end{array}$ & Pulp, peel, and seeds & $\begin{array}{l}\text { Ethyl acetate, } 70 \% \\
(v / v) \text { acetone, and } 70 \% \\
(v / v) \text { methanol }\end{array}$ & CUPRAC, DPPH, and ABTS & $\begin{array}{l}\text { Acetone }(70 \% v / v) \text { was found to } \\
\text { be the most effective solvent for } \\
\text { extracting antioxidants. Peel } \\
\text { and seed extracts exhibited } \\
\text { greater antioxidant values in all } \\
\text { three assays compared to pulp. }\end{array}$ & $\begin{array}{l}\text { Peels and seeds: catechins, } \\
\text { procyanidins, and } \\
\text { hydroxycinnamic acids } \\
\text { Pulp: hydroxybenzoic and } \\
\text { hydroxycinnamic acids and } \\
\text { procyanidin. }\end{array}$ & [104] \\
\hline $\begin{array}{l}\text { Hass and } \\
\text { Shepard }\end{array}$ & Seeds and peel & $80 \%(v / v)$ methanol & $\begin{array}{l}\text { HPLC-PAD, HPLC-ESI-MS, } \\
\text { DPPH, ABTS and ORAC }\end{array}$ & $\begin{array}{l}\text { The peel extracts displayed a } \\
\text { higher total phenolic } \\
\text { compound content and } \\
\text { antioxidant activity in } \\
\text { comparison to the seed extracts. } \\
\text { Hass variety had a higher } \\
\text { antioxidant capacity, which } \\
\text { might be attributed to its } \\
\text { procyanidin dimers and } \\
\text { catechins than the Shepard } \\
\text { variety. }\end{array}$ & $\begin{array}{l}\text { Seed and peel extracts } \\
\text { contained flavanol monomers, } \\
\text { proanthocyanidins, and } \\
\text { hydroxycinnamic acids. In } \\
\text { addition, flavonol glycosides } \\
\text { were detected in seed extracts. }\end{array}$ & [94] \\
\hline $\begin{array}{l}\text { Hass, } \\
\text { Lamb-Hass, } \\
\text { and Rugoro }\end{array}$ & Pulp & $\begin{array}{l}\text { Methanol, ethanol, } \\
\text { acetone, } \\
\text { and ethyl acetate }\end{array}$ & HPLC-DAD-ESI-TOF & $\begin{array}{l}\text { Seventeen compounds were } \\
\text { identified using standards. } \\
\text { Twenty-five compounds were } \\
\text { tentatively identified. }\end{array}$ & $\begin{array}{c}\text { Quinic acid, succinic acid, } \\
\text { pantothenic acid, } \\
p \text {-coumaroyl-D-glucose, } \\
\text { abscisic acid, pentadecylfuran, } \\
\text { avocado furan, and oleic acid } \\
\text { were the most common } \\
\text { compounds among the three } \\
\text { avocado varieties. }\end{array}$ & [92] \\
\hline $\begin{array}{c}\text { Hass, } \\
\text { Quintal, } \\
\text { Margarida, } \\
\text { and Fortuna }\end{array}$ & Peel, pulp, and seeds & Ethanol & ABTS, DPPH, FRAP & $\begin{array}{l}\text { Peel extract of the Quintal } \\
\text { variety showed the highest } \\
\text { antioxidant capacity in all three } \\
\text { assays. A similar trend was } \\
\text { observed in terms of total } \\
\text { phenolic and flavonoid } \\
\text { contents. }\end{array}$ & $\begin{array}{l}\text { Phenolics and flavonoids } \\
\text { might contribute to the } \\
\text { antioxidant capacity. }\end{array}$ & [99] \\
\hline
\end{tabular}


Table 3. Cont.

\begin{tabular}{|c|c|c|c|c|c|c|}
\hline Variety & Part Studied & Types of Extract & Detection Assays & Major Findings & Type of Antioxidants & References \\
\hline $\begin{array}{l}\text { Hass, Bacon, } \\
\text { Fuerte, } \\
\text { Pinkerton, } \\
\text { Rincon, and } \\
\text { Orotawa }\end{array}$ & Pulp & Methanol & UHPLC-HE-MS & $\begin{array}{l}\text { Pulp extracts had } 19 \text { individual } \\
\text { phenolic compounds. A } \\
\text { decrease in concentration of } \\
\text { epicatechin concentration was } \\
\text { observed with fruit ripening. }\end{array}$ & $\begin{array}{c}\text { Gallic acid, sinapinic acid, } \\
\text { vanillin, } p \text {-coumaric acid, } \\
\text { gentisic acid, protocatechuic } \\
\text { acid, 4-hydroxybenzoic acid, } \\
\text { chlorogenic acid, and benzoic } \\
\text { acid. }\end{array}$ & [89] \\
\hline $\begin{array}{c}\text { Hass, Hass } \\
\text { Motril, } \\
\text { ColinV 33, } \\
\text { Gem, } \\
\text { Harvest, } \\
\text { Jiménez 1, } \\
\text { Jiménez 2, } \\
\text { Lamb Hass, } \\
\text { Marvel, } \\
\text { Nobel, } \\
\text { Pinkerton, } \\
\text { Sir Prize and } \\
\text { Tacambaro }\end{array}$ & Pulp & Methanol & $\begin{array}{c}\text { GC coupled to APCI-TOF MS } \\
\text { and FID }\end{array}$ & $\begin{array}{l}\text { Twenty-seven compounds } \\
\text { were quantified by } \\
\text { GC-APCI-MS. Seven } \\
\text { compounds are quantified by } \\
\text { GC-FID. The concentration of } \\
\text { organic acids, flavonoids, and } \\
\text { vitamins decreased, whereas } \\
\text { phenolic acids, ferulic acids, or } \\
\text { p-coumaric acids increased } \\
\text { with the ripening } \\
\text { process. }\end{array}$ & $\begin{array}{l}\text { Quinic, ferulic, chlorogenic and } \\
\text { p-coumaric acids, epicatechin, } \\
\text { and quercetin. }\end{array}$ & [93] \\
\hline Collinson & Pulp & $\begin{array}{l}80 \% \text { methanol and } \\
\text { acetone }\end{array}$ & ABTS, DPPH, and FRAP & $\begin{array}{l}\text { Lipophilic extracts displayed } \\
\text { greater antioxidant capacity in } \\
\text { the ABTS and DPPH assays } \\
\text { compared to hydrophilic } \\
\text { extracts. The opposite trend } \\
\text { was observed in the FRAP } \\
\text { assay. }\end{array}$ & - & [113] \\
\hline
\end{tabular}


Table 3. Cont

\begin{tabular}{|c|c|c|c|c|c|c|}
\hline Variety & Part Studied & Types of Extract & Detection Assays & Major Findings & Type of Antioxidants & References \\
\hline Fortuna & Fresh and dried seeds & $\begin{array}{c}\text { Water, } 70 \%(v / v) \\
\text { ethanol, } 70 \%(v / v) \\
\text { methanol, and } \\
\text { partition with } \\
\text { n-hexane } \\
\text { chloroform, ethyl } \\
\text { acetate, and n-butanol }\end{array}$ & Spectroscopic and HPLC & $\begin{array}{l}\text { Ethanol extract of dried seed } \\
\text { showed } \\
\text { 50, 38, and } 24 \mathrm{mg} / \mathrm{g} \text { of dry } \\
\text { matter of total phenol, } \\
\text { condensed tannins, and } \\
\text { flavonoid contents, } \\
\text { respectively. HPLC study } \\
\text { revealed epicatechin }(4.7 \\
\mu \mathrm{g} / \mathrm{mL}), \text { rutin }(2.8 \mu \mathrm{g} / \mathrm{mL}), \text { and } \\
\text { chlorogenic acid }(1.4 \mu \mathrm{g} / \mathrm{mL}) \\
\text { and quercetin in the extract. }\end{array}$ & $\begin{array}{l}\text { Epicatechin, rutin, chlorogenic } \\
\text { acid, quercetin. }\end{array}$ & [114] \\
\hline Fortuna & Pulp & $\begin{array}{l}\text { Oil extracted with } \\
\mathrm{SCO}_{2} \text { and } \\
\text { compressed LPG }\end{array}$ & $\mathrm{DPPH}$ & $\begin{array}{l}\text { The } \mathrm{SCO}_{2} \text {-extracted oil } \\
\text { displayed higher antioxidant } \\
\text { activity in the range of } \\
\text { 17.4-82.5\% compared to } \\
\text { LPG-compressed oil. }\end{array}$ & - & [115] \\
\hline Fortuna & Pulp & $\begin{array}{l}\text { Lyophilized and cold } \\
\text { pressed oil }\end{array}$ & GC-FID and GC-MS & $\begin{array}{c}\text { A greater concentration of } \\
\alpha \text {-tocopherol and squalene } \\
\text { were achieved with cold } \\
\text { pressing. }\end{array}$ & $\alpha$-tocopherol and squalene. & [116] \\
\hline Fuerte & Pulp & Different solvents & FRAP, SOD and HPLC & $\begin{array}{l}\text { Increase in the total antioxidant } \\
\text { activity, SOD activity, and } \\
\alpha \text {-tocopherol content was } \\
\text { observed in the presence of } \\
\text { 1-MCP and low } \mathrm{O}_{2} \text {. }\end{array}$ & - & [117] \\
\hline Lula & Pulp & $\begin{array}{l}\text { Oil extracted with } \\
\text { water at high } \\
\text { temperatures }\end{array}$ & HPLC and spectroscopic assays & $\begin{array}{c}\text { Greater quantity of } \\
\alpha \text {-tocopherol was detected } \\
\text { compared to } \beta, \gamma, \text { and } \\
\delta \text {-tocopherols. In addition, } \\
\text { sterols and carotenoids were } \\
\text { also reported. }\end{array}$ & $\begin{array}{l}\text { Tocopherols, sterols, and } \\
\text { carotenoids were potent } \\
\text { antioxidants. }\end{array}$ & [118] \\
\hline $\begin{array}{l}\text { Mexican } \\
\text { landrace }\end{array}$ & Peel & Methanol & $\mathrm{DPPH}$ & $\begin{array}{c}\text { Antioxidant values in the range } \\
\text { of } 53.31-307.33 \mathrm{mmol} \text { trolox } \\
\text { equivalents/fresh weight were } \\
\text { reported. }\end{array}$ & $\begin{array}{l}\text { Activity can be attributed to } \\
\text { anthocyanins. }\end{array}$ & [119] \\
\hline
\end{tabular}


Table 3. Cont.

\begin{tabular}{|c|c|c|c|c|c|c|}
\hline Variety & Part Studied & Types of Extract & Detection Assays & Major Findings & Type of Antioxidants & References \\
\hline $\begin{array}{l}\text { Slimcado, } \\
\text { Booth 7, } \\
\text { Booth 8, } \\
\text { Choquette, } \\
\text { Loretta, } \\
\text { Simmonds, } \\
\text { and Tonnage }\end{array}$ & Pulp, peel, and seeds & $\begin{array}{c}\text { Acetone, water, acetic } \\
\text { acid }\end{array}$ & HPLC-MS, ORAC and DPPH & $\begin{array}{l}\text { Seed extracts exerted the } \\
\text { highest antioxidant activity, } \\
\text { phenolic content, and } \\
\text { procyanidins followed by peel } \\
\text { and pulp. Significant } \\
\text { correlations were observed } \\
\text { among antioxidant capacities, } \\
\text { phenolic contents, and } \\
\text { procyanidins. Antioxidant } \\
\text { activity can be attributed to the } \\
\text { procyanidin content. }\end{array}$ & $\begin{array}{l}\text { Catechin, epicatechin, A- and } \\
\text { B-type dimers, A- and B-type } \\
\text { trimers, tetramers, pentamers } \\
\text { and hexamers were identified } \\
\text { in peels and seeds. }\end{array}$ & [84] \\
\hline- & Pulp & $\begin{array}{l}\text { Supercritical } \mathrm{CO}_{2} / \\
\text { ethanol extracts }\end{array}$ & HPLC & $\begin{array}{l}\text { Supercritical } \mathrm{CO}_{2}+\text { ethanol at } \\
200 \text { bar and at } 40^{\circ} \mathrm{C} \text { and } 60^{\circ} \mathrm{C} \\
\text { yielded significantly higher } \\
\alpha \text {-tocopherol content. }\end{array}$ & $\alpha$-tocopherol & [120] \\
\hline- & Seeds and pulp & Lipid & ABTS and DPPH & $\begin{array}{l}\text { Seed extracts exhibited } \\
\text { significantly greater } \\
\text { antioxidant activity in both } \\
\text { assays. Dose-dependent } \\
\text { antioxidant activity was } \\
\text { observed for both extracts. }\end{array}$ & - & [98] \\
\hline- & Pulp & $\begin{array}{l}\text { Oil extracted with } \\
\text { mechanical pressing }\end{array}$ & $\mathrm{DPPH}$ & $\begin{array}{l}\text { Greater antioxidant values } \\
\text { were observed when the } \\
\text { avocado pulp was dried at } 60 \\
{ }^{\circ} \mathrm{C} \text { under ventilation, and } \\
\text { mechanical pressing was used } \\
\text { for the oil extraction compared } \\
\text { to vacuum oven and Soxhlet } \\
\text { extraction. }\end{array}$ & $\begin{array}{l}\alpha \text {-tocopherol, phenolic } \\
\text { compounds, carotenoids. }\end{array}$ & [121] \\
\hline- & Seeds & $\begin{array}{l}\text { Ultrasonic extraction } \\
\text { with water }\end{array}$ & ORAC & $\begin{array}{l}\text { Total antioxidant capacity } \\
\text { increased with an increase in } \\
\text { ultrasonic power. Positive } \\
\text { correlation was observed } \\
\text { between total polyphenolic } \\
\text { content and antioxidant } \\
\text { capacity. }\end{array}$ & - & [86] \\
\hline
\end{tabular}


Table 3. Cont

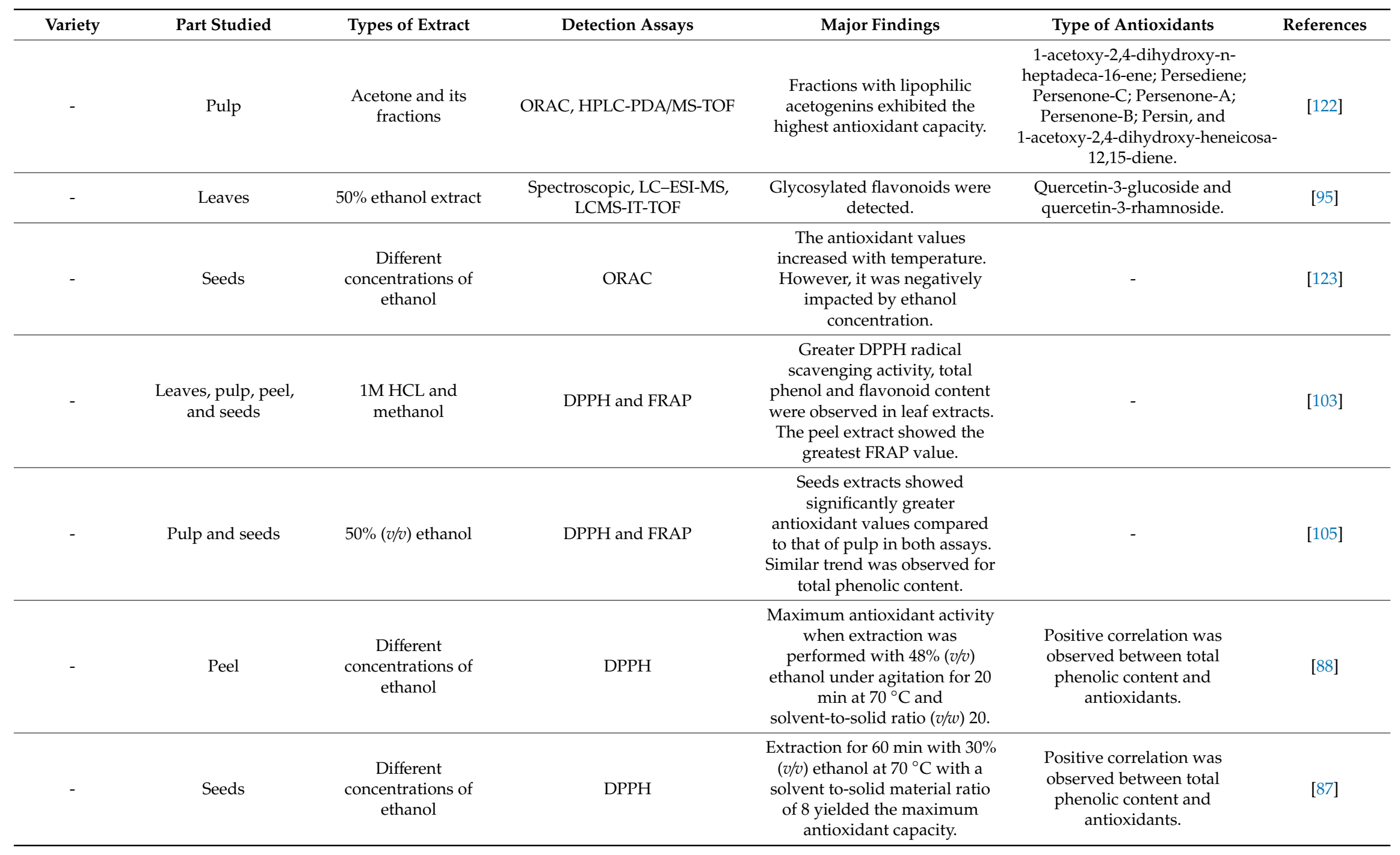


Table 3. Cont

\begin{tabular}{|c|c|c|c|c|c|c|}
\hline Variety & Part Studied & Types of Extract & Detection Assays & Major Findings & Type of Antioxidants & References \\
\hline- & Leaves & $\begin{array}{l}\text { Methanol, ethanol, } \\
\text { cold and hot water }\end{array}$ & $\begin{array}{l}\text { DPPH, FRAP, and hydroxyl } \\
\text { radical scavenging ability }\end{array}$ & $\begin{array}{l}\text { Significant antioxidant activity } \\
\text { was observed in all three } \\
\text { assays. }\end{array}$ & $\begin{array}{l}\text { Antioxidant activity might be } \\
\text { contributed by the phenolics } \\
\text { and flavonoids. }\end{array}$ & [124] \\
\hline- & Pulp & $\begin{array}{l}\text { Lipid-soluble } \\
\text { bioactive }\end{array}$ & $\begin{array}{l}\mathrm{DPPH}, \text { reducing power, metal } \\
\text { chelating, nitric oxide } \\
\text { scavenging, hydrogen peroxide } \\
\text { scavenging, } \\
\text { hemoglobin-induced linoleic } \\
\text { acid system }\end{array}$ & $\begin{array}{l}\text { Exhibited lower antioxidant } \\
\text { properties compared to } \\
\text { vitamin C. }\end{array}$ & - & [127] \\
\hline- & Pulp & Methanol + water & ABTS and TBARS & $\begin{array}{l}\text { Lower antioxidant activity was } \\
\text { reported compared to other } \\
\text { fruits tested in the study. }\end{array}$ & - & [128] \\
\hline- & Leaves and seeds & Water & $\begin{array}{l}\text { DPPH, NO radical scavenging } \\
\text { activity, inhibition of } \\
\text { degradation of deoxyribose, Fe } \\
\text { (II) chelating ability }\end{array}$ & $\begin{array}{l}\text { Higher phenolic content and } \\
\text { radical scavenging activity } \\
\text { were observed in leaf extract. } \\
\text { However, it showed lower iron } \\
\text { chelation activity compared to } \\
\text { the seed extract. }\end{array}$ & - & [129] \\
\hline- & Seeds & $\begin{array}{l}\text { Different solvents and } \\
\text { fractions }\end{array}$ & $\mathrm{DPPH}$ & $\begin{array}{l}\text { One fraction exhibited a radical } \\
\text { scavenging activity of } 81.6 \% \text {. }\end{array}$ & - & [130] \\
\hline
\end{tabular}


ABTS: 2,2'-azino-bis (3-ethylbenzothiazoline-6-sulfonic acid) diammonium salt.

TEAC: Trolox equivalent antioxidant capacity.

DPPH: 2,2-Diphenyl-1-picrylhydrazyl.

ORAC: Oxygen radical absorbance capacity.

HPLC-PDA: High-performance liquid chromatography-photodiode array.

HPLC-DAD-ESI-QTOF-MS: High-performance liquid chromatography-diode array detector-electrospray ionization-quadrupole time-of-flight mass spectrometry.

HPLC-ESI-QTOF-MS: High-performance liquid chromatography-electrospray ionization-quadrupole time-of-flight mass spectrometry.

FRAP: Ferric reducing ability of plasma.

CUPRAC: Cupric reducing antioxidant capacity.

SOD: Superoxide dismutase.

HPLC-MS: High-performance liquid chromatography mass spectrometry.

HPLC-ESI-MS: High-performance liquid chromatography-electrospray ionization-mass spectrometry.

LC-ESI-MS: Liquid chromatography-electrospray ionization-mass spectrometry.

UHPLC-HE-MS: Ultra high-performance liquid chromatography-heated electrospray-mass spectrometry.

TBARS: Thiobarbituric acid reactive substances.

HPLC-DAD-ESI-TOF: High performance liquid chromatography-diode array detector-electrospray ionization-time of flight.

GC-APCI-TOF-MS: Gas chromatography-atmospheric pressure chemical ionization-time-of-flight mass spectrometry.

GC-APCI-TOF-FID: Gas chromatography-atmospheric pressure chemical ionization-time-of-flight-flame ionization detector. 


\subsection{Anticancer Properties of P. americana}

Cancer causes more deaths than acquired immune deficiency syndrome, tuberculosis, malaria, and diabetes combined [131]. The greatest challenges of anticancer regimens are attributed to the complex mutational landscapes of cancer, late diagnoses, expensive therapeutic options, and the development of resistance to chemo and radiation therapies [132,133]. Chemotherapy-associated side effects and toxicity also make cancer one of the most challenging diseases to treat [133]. Natural products or their derivatives comprised over 45\% of the FDA-approved anticancer drugs between 1981-2010 [134]. In the United States, several plant-derived products, either alone or in conjunction with mainstream chemo and radiation therapies are used by approximately 50-60\% of cancer patients [132,135]. Therefore, the search for safer alternatives to be used either as mono or adjunct therapy with the standard drugs is becoming a priority in anticancer research [136]. The in vitro cytotoxic properties of avocado against different types of cancer cell lines including breast, colon, liver, lungs, larynx, leukemia, oesophageal, oral, ovary, and prostate have been extensively reported in the literature (Table 4). These properties have also been investigated in preclinical animal models. Interestingly, these in vitro and in vivo studies have not only explored the pulp, the most edible part of the fruit, but also the leaves, peel, and seeds of avocado. Table 4 depicts the major preclinical and clinical studies currently found in the literature emphasizing the potential anticancer activity of avocados. The chemical profiles of different parts of avocado vary among the varieties [84,137]. Therefore, rationally, depending on the chemical profiles, the bioactivities also vary accordingly. Many studies assessing the anti-proliferative activity of avocado did not report the varieties used. However, based on the limited studies that reported the varieties tested, Hass is perhaps the most explored cultivar for its anticancer properties. Molecular mechanistic studies in various cancer cell lines have reported the regulation of different signal transduction pathways, especially the induction of caspase-mediated apoptosis and the involvement of cell cycle arrest by different avocado extracts, their fractions, and isolated compounds (Figure 9, Table 4) [24,26,138-145]. For instance, Dabas et al. [140] recently found out that the methanol extract of Hass avocado seeds induced caspase 3-mediated apoptosis, poly (ADP-ribose) polymerase (PARP) cleavage, and cell cycle arrest at $G_{0} / G_{1}$, as well as reduced the nuclear translocation of nuclear factor kappa-B (NF- $\kappa$ B) and downregulated the cyclin D1 and E2 in lymph node carcinoma of the prostate (LNCaP) cells. Parallel observations were made earlier by Lee et al. [144] in MDA-MB-231 (MD Anderson metastasis breast cancer) cells using methanol extracts of avocado seeds and peel. They observed the activation of caspase-3 and its target protein- PARP, in MDA-MB-231 cells. Bonilla-Porras et al. [138] found out that ethanol extracts of avocado endocarp, seeds, whole seeds, and leaves activated transcription factor p53, caspase-3, apoptosis-inducing factor, and oxidative stress-dependent apoptosis via mitochondrial membrane depolarization in Jurkat lymphoblastic leukaemia cells. The acetone extract of avocado pulp rich in lutein, zeaxanthin, $\beta$-cryptoxanthin, $\alpha$-carotene, $\beta$-carotene, $\alpha$-tocopherol, and $\gamma$-tocopherol was shown to arrest the PC-3 prostate cancer cells at the $\mathrm{G}_{2} / \mathrm{M}$ phase and increase the expression of p27 protein [24]. The cytotoxic properties of different classes of compounds contribute to the cumulative anticancer activity of avocado. For example, the anticancer effects of the fatty alcohols, carotenoids, and phenolics were further augmented by the potential anticancer effect of norlignans/neolignans (Figure 7) from P. obovatifolia [48-53]. 


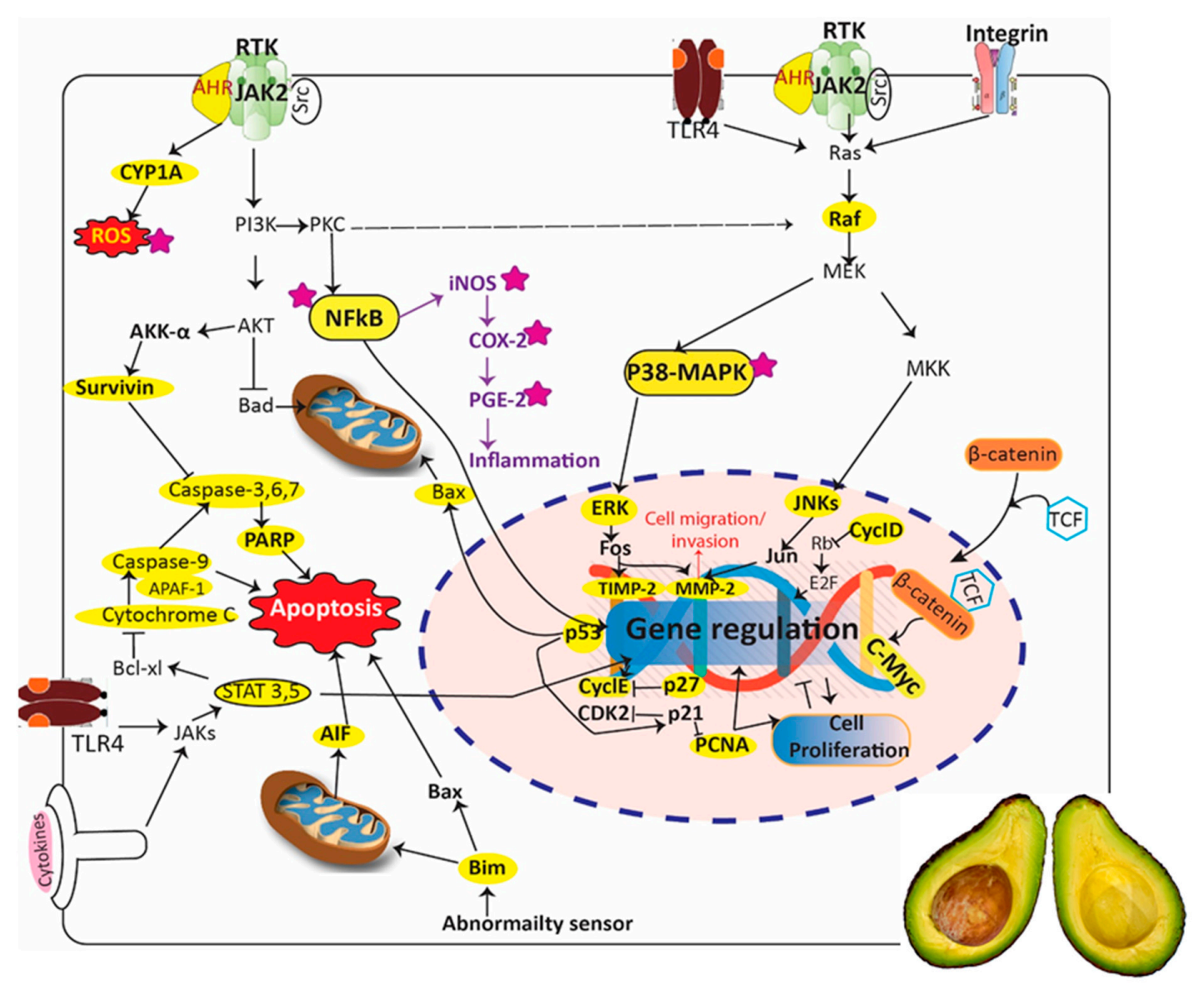

Figure 9. Effect of Persea americana (avocado) and its components on different cellular signal transduction pathways. The molecular targets highlighted in yellow play key roles in the proliferation, survival, migration/invasion, and apoptosis of cancer cells. Purple stars indicate the molecular targets involved in inflammatory response.

Scopoletin, a plant coumarin and phytoalexin found in avocado, reduced the carcinogens-induced toxicity and the size of skin papilloma in vivo [26]. Further mechanistic study revealed the modulation of various key cell cycle, apoptotic and tumor invasion markers by scopoletin. Notably, the downregulation of AhR (aryl hydrocarbon receptor), CYP1A1 (cytochrome P450 1A1), PCNA (proliferating cell nuclear antigen), stat-3 (signal transducer and activator of transcription 3), survivin, MMP-2 (matrix metalloproteinase-2), cyclin D1 and c-myc (avian myelocytomatosis virus oncogene cellular homolog); and the upregulation of p53, caspase-3 and TIMP-2 (tissue inhibitor of metalloproteinases-2) by scopoletin were demonstrated [26]. Of note, the expression of p53 and its target genes ( 500$)$ regulate a wide range of cellular processes, including apoptosis, cell cycle arrest, and DNA repair [146]. Additionally, the upregulation of TIMP-2 inhibits MMP-2 expression, which consecutively leads to the reduction of cellular migration and invasion (metastasis) [147,148]. Therefore, MMP-2 upregulation has been correlated with poor prognosis and relapse in cancer patients [147]. Another study by Roberts et al. [149] also indicated synergistic interaction between the breast cancer standard drug-tamoxifen —and persin isolated from avocado leaves against MCF-7 (Michigan cancer foundation-7), T-47D, and SK-Br3 breast cancer cells in vitro. The authors reported a significant reduction of tamoxifen $\mathrm{IC}_{50}$ values when it was combined with avocado persin. The synergistic interaction was Bim-dependent and mediated by the modulation of ceramide metabolism [149]. Bim is a member of the Bcl-2 (B-cell lymphoma 2) family of proteins that play a key role in the intrinsic (mitochondrial) pathway of apoptosis [150,151]. In particular, Bim is linked with microtubule-stabilizing properties, which mediate the formation of microtubule bundles with subsequent mitotic arrest and apoptosis [139,152]. 
Chemical synthesis of the most potent anticancer compounds found in avocado has also been carried out in a number of studies $[143,145,153,154]$. Similar to avocado crude extracts, chemically synthesized avocado peptide PaDef defensin was recently found to induce apoptosis via caspase 7, 8, and 9 expressions in K562 chronic myeloid leukaemia and MCF-7 breast cancer cells in two studies by the same research group $[143,153]$. Moreover, PaDef defensin was previously demonstrated to have antimicrobial properties $[155,156]$. The induction of apoptosis and abrogation of the cell cycle were also observed earlier in the human breast, lung, ovarian, and colorectal cancer cells when treated with chemically synthesized avocado $\beta$-hydroxy- $\alpha, \beta$-unsaturated ketones by Leon et al. [145]. Although many preclinical studies were performed to elucidate the cytotoxicity of extracts derived from different parts of the avocado plant and their components, very few of them have investigated their molecular mechanisms of action. Interestingly, contradicting information regarding avocado extract-induced genotoxicity is also available. For instance, Kulkarn et al. [157] found out that avocado fruit and leaf extracts can induce chromosomal aberrations in human peripheral lymphocytes, with leaf extract being more genotoxic. The same research group later reported that avocado fruit extract can reduce cyclophosphamide-mediated chromosomal aberrations in human lymphocytes [158], which was perhaps due to the antagonistic effects of the extract on cyclophosphamide.

Traditionally, an avocado leaf decoction is used for the treatment of tumors and tumor-related diseases in Nigeria [159]. Despite their health benefits highlighted in numerous reports, clinical studies examining the direct correlation between avocado consumption and the prevention and treatment of cancer are scarce. Only one case-control study involving 243 men with prostate cancer and 273 controls in Jamaica demonstrated that MUFA from avocado may reduce the risk of prostate cancer [160]. However, it should be noted that bioactive compounds that are also commonly found in avocados such as $\alpha$-carotene, $\beta$-cryptoxanthin, lycopene, lutein, and zeaxanthin were found to have inverse associations with cancers of the mouth, larynx, pharynx, and breast in few clinical trials, as highlighted in Table 5 [161-163]. According to the USDA, avocados contain a significantly higher amount of glutathione per average serving compared to other fruits [61]. Glutathione is a potent tripeptide antioxidant that plays a major role in detoxification pathways and the reduction of oxidative stress and risk of cancer $[62,65]$. Notably, it has been linked with the reduction of chemotherapy-associated toxicity and risks of oral cancer in a few clinical studies [57-59,164]. Nonetheless, the molecular mechanism of how glutathione reduces the side effects of chemotherapeutic regimens remains largely speculative. In order to precisely understand the anticancer mechanisms of action of avocado extracts and their bioactive compounds, more in vitro and in vivo studies are warranted. As very few studies have identified the solitary bioactive compounds responsible for the growth inhibition of different cancer cells, more research should be undertaken to gain a comprehensive understanding of the chemical profiles of the active extracts. Notably, bioassay-guided fractionation and the subsequent isolation and characterization of biologically active compounds from different parts of the avocado plant may lead to the identification of many novel anticancer compounds. Randomized controlled trials should be designed to evaluate the efficacy of bioactive compounds derived from avocado in the prevention and treatment of different cancer types. Furthermore, the chemoprotective properties of avocado and the possibility of using its bioactive compounds as an adjunct therapy for cancer should also be explored. 
Table 4. Preclinical and clinical studies highlighting the anticancer properties of Persea americana (avocado).

\begin{tabular}{|c|c|c|c|c|c|c|}
\hline \multicolumn{7}{|c|}{ Preclinical Studies } \\
\hline Variety & Parts & Type of Extracts & Bioactive Compounds & Type of Cell Lines & $\begin{array}{l}\text { Major Findings and Molecular } \\
\text { Mechanisms of Action }\end{array}$ & References \\
\hline Hass & Seeds & Methanol & - & $\begin{array}{l}\text { MCF-7 } \\
\text { breast, H1299 lung, } \\
\text { HT29 colon, and } \\
\text { LNCaP prostate } \\
\text { cancer cells }\end{array}$ & $\begin{array}{c}\text { Dose-dependent inhibition of all cells } \\
\text { with IC } \mathrm{IC}_{50} \text { values } 19-132 \mu \mathrm{g} / \mathrm{mL} \text { after } 48 \mathrm{~h} \\
\text { of treatment. In LNCaP prostate cancer } \\
\text { cells, the induction of caspase } \\
\text { 3-mediated apoptosis, PARP cleavage, } \\
\text { downregulation of cyclin D1 and E2, cell } \\
\text { cycle arrest at } \mathrm{G}_{0} / \mathrm{G}_{1} \text { phase and } \\
\text { reduction of nuclear translocation of } \\
\text { nuclear factor kappa B (NF- } \kappa \mathrm{B} \text { ) were } \\
\text { observed. }\end{array}$ & [140] \\
\hline Hass & Seeds & $\begin{array}{l}\text { High-speed } \\
\text { countercurrent } \\
\text { chromatographic } \\
\text { fraction of } \\
\text { methanol-water } \\
\text { partition (M7) } \\
\end{array}$ & $\begin{array}{l}\text { Proanthocyanidins B1, B2 and A-type } \\
\text { trimer. Traces of abscisic acid glucosides. }\end{array}$ & $\begin{array}{l}\text { HaCaT immortalized } \\
\text { nontumorigenic } \\
\text { human epidermal } \\
\text { cells }\end{array}$ & $\begin{array}{l}\text { Significant inhibition of cell } \\
\text { proliferation, increased LDH activity. } \\
\text { Molecular mechanisms of action were } \\
\text { not investigated. }\end{array}$ & [23] \\
\hline Hass & Pulp & Chloroform-soluble & $\begin{array}{c}\text { Two aliphatic } \\
\text { acetogenins- } \\
(2 \mathrm{~S}, 4 \mathrm{~S})-2,4 \text {-dihydroxyheptadec } \\
\text { 16-enyl acetate] and 2 } \\
{[(2 \mathrm{~S}, 4 \mathrm{~S})-2,4-\text { dihydroxyheptadec-16-ynyl }} \\
\text { acetate. }\end{array}$ & $\begin{array}{l}\text { 83-01-82CA human } \\
\text { oral cancer cell line, } \\
\text { MEK overexpressing } \\
\text { cell line } \\
\text { 83-01-82CA/MEKCA }\end{array}$ & $\begin{array}{c}\text { The two aliphatic acetogenins targeted } \\
\text { the EGFR/RAS/RAF/MEK/ERK1/2 cancer } \\
\text { pathway by synergistically inhibiting } \\
\text { c-RAF (Ser338) and ERK1/2 } \\
\text { (Thr202/Tyr204) phosphorylation. }\end{array}$ & [165] \\
\hline Hass & Pulp & Chloroform & - & $\begin{array}{l}\text { 83-01-82CA human } \\
\text { oral cancer and } \\
\text { TE1177 } \\
\text { normal epithelial cell } \\
\text { lines } \\
\end{array}$ & $\begin{array}{l}\text { In the oral cancer cells, the extract } \\
\text { induced apoptosis by increasing the } \\
\text { levels of reactive oxygen species by } \\
\text { twofold to threefold. Apoptosis was not } \\
\text { induced in the normal cell line. }\end{array}$ & {$[141,142]$} \\
\hline Hass & Pulp & Acetone & $\begin{array}{c}\text { Lutein, zeaxanthin, } \\
\beta \text {-cryptoxanthin, } \alpha \text {-carotene, and } \\
\beta \text {-carotene, } \alpha \text {-tocopherol and } \\
\gamma \text {-tocopherol. }\end{array}$ & $\begin{array}{c}\text { LNCaP } \\
\text { androgen-dependent } \\
\text { and PC-3 } \\
\text { androgen-independent } \\
\text { prostate cancer cell } \\
\text { lines }\end{array}$ & $\begin{array}{l}\text { Inhibited the growth of both the prostate } \\
\text { cancer cell lines. Arrested PC- } 3 \text { cells at } \\
\text { the } \mathrm{G}_{2} / \mathrm{M} \text { phase and increased the } \\
\text { expression of p27 protein. }\end{array}$ & [24] \\
\hline
\end{tabular}


Table 4. Cont.

\begin{tabular}{|c|c|c|c|c|c|c|}
\hline \multicolumn{7}{|c|}{ Preclinical Studies } \\
\hline Variety & Parts & Type of Extracts & Bioactive Compounds & Type of Cell Lines & $\begin{array}{l}\text { Major Findings and Molecular } \\
\text { Mechanisms of Action }\end{array}$ & References \\
\hline Lulu & $\begin{array}{l}\text { Unripe fruit } \\
\text { pulp }\end{array}$ & $\begin{array}{l}95 \%(v / v) \text { ethanol } \\
\text { extracts and its } \\
\text { fractions }\end{array}$ & $\begin{array}{l}\text { 1,2,4-Trihydroxynonadecane, } \\
\text { 1,2,4-Trihydroxyheptadec-16-ene and } \\
\text { 1,2,4-Trihydroxyheptadec-16-yne. }\end{array}$ & $\begin{array}{l}\text { A-549 human lung, } \\
\text { MCF-7 human breast, } \\
\text { HT-29 human colon, } \\
\text { A-498 human } \\
\text { Kidney, MIA PaCa-2 } \\
\text { human pancreatic } \\
\text { carcinoma, PC-3 } \\
\text { human prostate } \\
\text { cancer cells }\end{array}$ & $\begin{array}{l}\text { All three compounds were active against } \\
\text { six human tumor cell lines and exhibited } \\
\text { selectivity against PC-3 cells. Molecular } \\
\text { mechanisms were not studied. }\end{array}$ & [21] \\
\hline- & Seeds & $\begin{array}{l}\text { Ethanol extract and } \\
\text { its hexane and } \\
\text { dichloromethane } \\
\text { fractions }\end{array}$ & - & $\begin{array}{l}\text { Lung A549 and } \\
\text { gastric BGC } 823 \text { cancer } \\
\text { cells }\end{array}$ & $\begin{array}{l}\text { Growth inhibition at } 200 \mu \mathrm{g} / \mathrm{mL} \text {. The } \\
\mathrm{IC}_{50} \text { values and molecular mechanisms } \\
\text { of action were not investigated. }\end{array}$ & [166] \\
\hline- & $\begin{array}{l}\text { Pulp and } \\
\text { seed extracts }\end{array}$ & Lipids & Fatty acids, hydrocarbon, and sterols. & $\begin{array}{l}\text { HCT116 colon and } \\
\text { HePG2 } \\
\text { liver cancer cell lines }\end{array}$ & $\begin{array}{c}\text { Seed extract showed greater activity } \\
\text { against HCT116 }\left(\mathrm{IC}_{50}<4 \mu \mathrm{g} / \mathrm{mL}\right) \text { and } \\
\text { HePG2 }\left(\mathrm{IC}_{50}<20 \mu \mathrm{g} / \mathrm{mL}\right) \text { cell lines } \\
\text { compared to the pulp extract. Molecular } \\
\text { mechanisms of action were not } \\
\text { investigated. }\end{array}$ & [98] \\
\hline- & Seeds & $\begin{array}{l}\text { Chloroform extracts } \\
\text { and its soluble } \\
\text { methanol fraction } \\
\text { (FML) and } \\
\text { non-soluble methanol } \\
\text { fraction (FTML). }\end{array}$ & - & $\begin{array}{l}\text { MCF-7 breast cancer } \\
\text { cell line }\end{array}$ & $\begin{array}{l}\text { Chloroform extract, FML, and FTML } \\
\text { inhibited cell growth in a } \\
\text { dose-dependent manner and displayed } \\
\mathrm{IC}_{50} \text { values of } 94.87,34.52 \text {, and } 66.03 \\
\mu \mathrm{g} / \mathrm{mL} \text {, respectively. FML induced } \\
\text { apoptosis and arrested cells at the } \\
\text { subG }{ }_{1} / \mathrm{G}_{0} \text { phase. }\end{array}$ & [167] \\
\hline- & Leaves & Silver nanoparticles & & $\begin{array}{l}\text { MCF-7 breast and } \\
\text { HeLa cervical cancer } \\
\text { cells }\end{array}$ & $\begin{array}{l}\text { Dose-dependent cytotoxicity was } \\
\text { observed at concentrations above } 50 \mu \mathrm{M} \\
\text { in MCF-7 but not in HeLa cells. } \\
\text { Downregulation of p53 expression was } \\
\text { observed in both cell lines. }\end{array}$ & [168] \\
\hline
\end{tabular}


Table 4. Cont.

\begin{tabular}{|c|c|c|c|c|c|c|}
\hline \multicolumn{7}{|c|}{ Preclinical Studies } \\
\hline Variety & Parts & Type of Extracts & Bioactive Compounds & Type of Cell Lines & $\begin{array}{l}\text { Major Findings and Molecular } \\
\text { Mechanisms of Action }\end{array}$ & References \\
\hline- & Leaves & $\begin{array}{l}\text { Aqueous-ethanol }(5 \% \\
\mathrm{v} / \mathrm{v})\end{array}$ & - & Larynx cancer tissue & $\begin{array}{c}\text { Significant increase in adenosine } \\
\text { deaminase activity in cancerous tissues } \\
\text { derived from } 13 \text { patients who } \\
\text { underwent surgery for larynx cancer } \\
\text { (median age of } 57 \text { years) compared to } \\
\text { noncancerous }(r=0.60, p=0.029 \text { ) tissues. }\end{array}$ & [169] \\
\hline- & Seeds & $\begin{array}{c}\text { Fraction of ethanol } \\
\text { extract }\end{array}$ & Triterpenoid & $\begin{array}{l}\text { MCF-7 breast and } \\
\text { HepG2 liver cancer } \\
\text { cells }\end{array}$ & $\begin{array}{c}\text { Inhibited MCF-7 }\left(\mathrm{IC}_{50}=62 \mu \mathrm{g} / \mathrm{mL}\right) \text { and } \\
\text { HepG2 }\left(\mathrm{IC}_{50}=12 \mu \mathrm{g} / \mathrm{mL}\right) \text { cells with no } \\
\text { activity against normal cells. Molecular } \\
\text { mechanisms of action were not } \\
\text { investigated. }\end{array}$ & [170] \\
\hline- & Pulp & $\begin{array}{l}\text { Ethanol, chloroform, } \\
\text { ethyl acetate, and } \\
\text { petroleum. }\end{array}$ & - & $\begin{array}{c}\text { Esophageal } \\
\text { squamous cell } \\
\text { carcinoma and colon } \\
\text { adenocarcinoma cell } \\
\text { line }\end{array}$ & $\begin{array}{l}\text { Moderate activity. The } \mathrm{IC}_{50} \text { values and } \\
\text { molecular mechanisms of action were } \\
\text { not investigated. }\end{array}$ & [171] \\
\hline- & Pulp & Aqueous & - & $\begin{array}{l}\text { A549 lung, HepG-2 } \\
\text { liver, HT-29 colon, } \\
\text { and MCF-7 breast } \\
\text { cancer cells. }\end{array}$ & $\begin{array}{l}\text { Exhibited } \mathrm{LC}_{50} \text { values in the range of } \\
13.3-54.5 \mu \mathrm{g} / \mathrm{mL} \text { against the tested cell } \\
\text { lines. Molecular mechanisms of action } \\
\text { were not investigated. }\end{array}$ & [172] \\
\hline- & Root bark & $\begin{array}{l}\text { Methanol extract and } \\
\text { its fractions. }\end{array}$ & $\begin{array}{l}\text { 4-hydroxy-5-methylene-3- } \\
\text { undecyclidenedihydrofuran-2 (3H)- } \\
\text { one }\end{array}$ & $\begin{array}{l}\text { MCF-7 breast cancer } \\
\text { cell line }\end{array}$ & $\begin{array}{c}\text { Antiproliferative activity with an } \mathrm{IC}_{50} \\
\text { value of } 20.48 \mu \mathrm{g} / \mathrm{mL} \text { with induction of } \\
\text { apoptosis. }\end{array}$ & [36] \\
\hline- & $\begin{array}{l}\text { Endocarp, } \\
\text { whole seed, } \\
\text { seed and } \\
\text { leaves }\end{array}$ & Ethanol & - & $\begin{array}{c}\text { Jurkat } \\
\text { lymphoblastic } \\
\text { leukemia cells }\end{array}$ & $\begin{array}{l}\text { Induced significant oxidative } \\
\text { stress-dependent apoptosis via } \\
\text { mitochondrial membrane } \\
\text { depolarization. Activated transcription } \\
\text { factor p53, protease caspase-3, and } \\
\text { apoptosis-inducing factor (APAF). }\end{array}$ & [138] \\
\hline- & Pulp & $50 \%(v / v)$ Methanol & - & $\begin{array}{l}\text { Human lymphocyte } \\
\text { cells }\end{array}$ & $\begin{array}{l}\text { Chemoprotective against } \\
\text { cyclophosphamide-induced } \\
\text { chromosomal aberrations at } 200 \mathrm{mg} / \mathrm{kg} \\
\text { body weight. }\end{array}$ & [158] \\
\hline
\end{tabular}


Table 4. Cont.

\begin{tabular}{|c|c|c|c|c|c|c|}
\hline \multicolumn{7}{|c|}{ Preclinical Studies } \\
\hline Variety & Parts & Type of Extracts & Bioactive Compounds & Type of Cell Lines & $\begin{array}{l}\text { Major Findings and Molecular } \\
\text { Mechanisms of Action }\end{array}$ & References \\
\hline- & $\begin{array}{l}\text { Seeds and } \\
\text { peel }\end{array}$ & Methanol & - & $\begin{array}{l}\text { MDA-MB- } 231 \text { breast } \\
\text { cancer cells }\end{array}$ & $\begin{array}{l}\text { Apoptosis due to activation of caspase-3 } \\
\text { and its target protein, PARP. }\end{array}$ & [144] \\
\hline \multirow[t]{2}{*}{-} & \multirow[t]{2}{*}{ Leaves } & \multirow[t]{2}{*}{-} & \multirow[t]{2}{*}{ Persin } & $\begin{array}{c}\text { In vitro: } \\
\text { MDA-MB-231, } \\
\text { MCF-7, and T-47D } \\
\text { breast cancer cells } \\
\text { In vivo: } \\
\text { Quackenbush } \\
\text { lactating mice }\end{array}$ & $\begin{array}{l}\text { In vitro: Persin selectively arrested cells } \\
\text { at the } \mathrm{G}_{2} / \mathrm{M} \text { phase and induced } \\
\text { caspase-dependent apoptosis. } \\
\text { Apoptosis was dependent on the } \\
\text { expression of Bim protein, which also } \\
\text { indicated the microtubule-stabilizing } \\
\text { properties of persin. Overall, MCF-7 and } \\
\text { T-47D cells were more sensitive to persin } \\
\text { compared to MDA-MB- } 231 \text {. } \\
\text { In vivo: Persin exerted cytotoxicity in } \\
\text { the lactating mammary epithelium. }\end{array}$ & [139] \\
\hline & & & & $\begin{array}{l}\text { MCF-7, T-47D, and } \\
\text { SK-Br3 breast cancer } \\
\text { and MCF-10A human } \\
\text { mammary epithelial } \\
\text { cells. }\end{array}$ & $\begin{array}{l}\text { Synergistic interaction between } \\
\text { tamoxifen and persin against the tested } \\
\text { breast cancer cells was observed. } \\
\text { Significant reduction of } \mathrm{IC}_{50} \text { values of } \\
\text { tamoxifen when combined with } 13.8 \\
\mu \mathrm{mol} / \mathrm{L} \text { of persin. The synergistic } \\
\text { cytotoxicity was Bim-dependent and } \\
\text { mediated by the modulation of ceramide } \\
\text { metabolism. }\end{array}$ & [149] \\
\hline- & Fruit & - & Persenone A & $\begin{array}{l}\text { In vitro: RAW } 264.7 \\
\text { mouse macrophage } \\
\text { cells } \\
\text { In vivo: Female ICR } \\
\text { mice ( } 7 \text { weeks old) }\end{array}$ & $\begin{array}{l}\text { Downregulated the expression of } \\
\text { iNOS/COX-2 (nitric oxide } \\
\text { synthase/cyclooxygenase-2) in } \\
\text { macrophage cells. When applied } \\
\text { topically, reduced the generation of } \\
\mathrm{H}_{2} \mathrm{O}_{2} \text { in mouse skin. }\end{array}$ & [173] \\
\hline- & Fruit & - & $\begin{array}{l}\text { (2R)-(12Z,15Z)-2-hydroxy-4-oxoheneicosa- } \\
\text { 12,15-dien-1-yl acetate (1), } \\
\text { persenone A (2) and B (3) }\end{array}$ & $\begin{array}{c}\text { HL- } 60 \text { acute } \\
\text { promyelocytic } \\
\text { leukemia and RAW } \\
264.7 \text { mouse } \\
\text { macrophage cells. }\end{array}$ & $\begin{array}{c}\text { Suppressed the growth of HL- } 60 \text { cells } \\
\text { (compound } 1, \mathrm{IC}_{50}=33.7 ; \text { compound } 2 \text {, } \\
\mathrm{IC}_{50}=1.4 ; \text { compound } 33, \mathrm{IC}_{50}=1.8 \mu \mathrm{M} \text { ). } \\
\text { Inhibited nitric oxide generation } \\
\text { induced by lipopolysaccharide in } \\
\text { combination with interferon- } \gamma \text { in RAW } \\
264.7 \text { cells. }\end{array}$ & [19] \\
\hline
\end{tabular}


Table 4. Cont.

\begin{tabular}{|c|c|c|c|c|c|}
\hline \multicolumn{6}{|c|}{ Preclinical Studies } \\
\hline Variety & Type of Extracts & Bioactive Compounds & Type of Cell Lines & $\begin{array}{l}\text { Major Findings and Molecular } \\
\text { Mechanisms of Action }\end{array}$ & References \\
\hline- & - & Scopoletin & $\begin{array}{l}\text { In vivo: Skin } \\
\text { papilloma in mice } \\
\text { induced by } \\
\text { 7,12-dimethylbenz(a) } \\
\text { anthracene and } \\
\text { croton oil }\end{array}$ & $\begin{array}{l}\text { Reduced carcinogen-induced toxicity } \\
\text { and led to decrease in the size of skin } \\
\text { papilloma. Downregulated AhR, } \\
\text { CYP1A1, PCNA, stat-3, survivin, } \\
\text { MMP-2, cyclin D1, and c-myc, and } \\
\text { upregulated p53, caspase-3, and TIMP-2. }\end{array}$ & [26] \\
\hline Chemica & esis & Type of $c$ & & $\begin{array}{l}\text { Major findings and molecular } \\
\text { mechanisms of action }\end{array}$ & References \\
\hline \multirow{2}{*}{\multicolumn{2}{|c|}{ Antimicrobial peptide-PaDef defensin }} & K562 chronic myel & mia cells & $\begin{array}{l}\text { Cytotoxic with an } \mathrm{IC}_{50} \text { value of } 97.3 \\
\mu \mathrm{g} / \mathrm{mL} \text {. Activated caspase- } 8 \text { and induced } \\
\text { the expression of TNF- } \alpha \text {. }\end{array}$ & [153] \\
\hline & & \multicolumn{2}{|c|}{ MCF-7 breast cancer cell line } & $\begin{array}{l}\text { Inhibited the growth in a } \\
\text { concentration-dependent manner }\left(\mathrm{IC}_{50}\right. \\
=141.62 \mu \mathrm{g} / \mathrm{mL} \text { ). Induced cytochrome } \mathrm{c} \text {, } \\
\text { APAF-1, and the caspase } 7 \text { and } 9 \\
\text { expressions, loss of mitochondrial } \Delta \psi \mathrm{m} \\
\text { and enhanced the phosphorylation of } \\
\text { MAPK p38. }\end{array}$ & [143] \\
\hline \multicolumn{2}{|c|}{ Persin and tetrahydropersin } & \multicolumn{2}{|c|}{$\begin{array}{c}\text { Breast cancer: MCF-7, T-47D, } \\
\text { MDA-MB-468, MDA-MB-157, SkBr3, Hs578T, MDA-MB-231 cells, } \\
\text { normal mammary epithelial MCF-10A cells, } \\
\text { Ovarian cancer: OVCAR3 and IGROV-1 cells } \\
\text { Prostate cancer: PC-3 and LNCaP cells }\end{array}$} & $\begin{array}{l}\text { Persin was more potent compared to } \\
\text { tetrahydropersin against most of the } \\
\text { tested cancer cell lines with } \mathrm{IC}_{50} \text { values } \\
\text { in the range } 15.1 \pm 1.3 \text { to more than } 39 \\
\mu \mathrm{M} \text {. Molecular mechanisms of action } \\
\quad \text { was not studied. }\end{array}$ & [154] \\
\hline \multicolumn{2}{|c|}{$\beta$-Hydroxy- $\alpha, \beta$-unsaturated ketones } & \multicolumn{2}{|c|}{$\begin{array}{l}\text { A2780 human ovarian, SW1573 lung, HBL-100 human breast, } \\
\text { T-47D human breast and WiDr colorectal cancer cells. }\end{array}$} & $\begin{array}{l}\mathrm{GI}_{50} \text { values in the range of } 0.5-3.9 \mu \mathrm{M} \text {. } \\
\text { Induced apoptosis and dose-dependent } \\
\text { cell cycle arrest in the } S \text { and } G_{2} / \mathrm{M} \text { phase. }\end{array}$ & [145] \\
\hline \multicolumn{6}{|c|}{ Case-control studies } \\
\hline \multicolumn{2}{|c|}{ Type of cancer } & \multicolumn{3}{|c|}{ Major findings } & References \\
\hline \multicolumn{2}{|c|}{ Prostate cancer } & \multicolumn{3}{|c|}{$\begin{array}{c}\text { A study involving } 243 \text { men with prostate cancer and } 273 \text { controls in Jamaica reported that monounsaturated } \\
\text { fat from avocado was associated with reduced risk of prostate cancer. }\end{array}$} & [160] \\
\hline
\end{tabular}


Table 5. Clinical studies demonstrating the anticancer activity of bioactive compounds that are also commonly found in Persea americana (avocado).

\begin{tabular}{|c|c|c|c|c|}
\hline Bioactive Compounds & Type of Cancer & Type of Study & Major Findings & References \\
\hline \multirow{3}{*}{$\begin{array}{c}\text { Carotenoids- } \alpha \text {-carotene, } \\
\beta \text {-cryptoxanthin, lycopene, and } \\
\text { lutein/zeaxanthin }\end{array}$} & \multirow{2}{*}{ Breast cancer } & $\begin{array}{l}\text { A nested case-control study in women } \\
\text { consisting of } 604 \text { breast cancer cases } \\
\text { and } 626 \text { controls. }\end{array}$ & $\begin{array}{l}\text { In women with high mammographic } \\
\text { density, plasma levels of carotenoids } \\
\text { reduced breast cancer risk significantly } \\
\quad(40-50 \% \text { reduction, } p<0.05) \text {. }\end{array}$ & [162] \\
\hline & & $\begin{array}{c}\text { An ancillary study involving } 207 \\
\text { women ages } 18 \text { to } 70 \text { years who had } \\
\text { been successfully treated for early-stage } \\
\text { breast cancer. }\end{array}$ & $\begin{array}{l}\text { An inverse association between total } \\
\text { plasma carotenoid concentrations and } \\
\text { the oxidative stress biomarkers (urinary } \\
\text { 8-hydroxy-2'-deoxyguanosine and } \\
\text { 8-isoprostaglandin-F2 } \alpha \text { ) was observed. }\end{array}$ & [163] \\
\hline & $\begin{array}{l}\text { Larynx, pharynx and oral } \\
\text { cancers }\end{array}$ & $\begin{array}{l}\text { The study population involving } 52 \\
\text { patients curatively treated for } \\
\text { early-stage larynx, pharynx or oral } \\
\text { cavity during 1997-2001. }\end{array}$ & $\begin{array}{c}\text { An inverse association was observed } \\
\text { between individual/grouped } \\
\text { xanthophylls and urinary } \\
\text { F2-isoprostanes ( } \mathrm{F}_{2} \text {-IsoPs), a biomarker } \\
\text { of oxidative stress. However, } \\
\text { individual/grouped carotenes did not } \\
\text { show such association with } \mathrm{F}_{2} \text {-IsoPs. }\end{array}$ & [161] \\
\hline \multirow{3}{*}{ Glutathione } & Advanced colorectal carcinoma & $\begin{array}{l}\text { A randomized, double blind, } \\
\text { placebo-controlled trial in } 52 \text { patients. }\end{array}$ & $\begin{array}{l}\text { Prevented of oxaliplatin-induced } \\
\text { neuropathy without reducing the } \\
\text { clinical efficacy of oxaliplatin. }\end{array}$ & [57] \\
\hline & Ovarian cancer & $\begin{array}{l}\text { A multicenter, randomized, } \\
\text { double-blind, parallel group design } \\
\text { with } 51 \text { women. }\end{array}$ & $\begin{array}{l}\text { Reduced the cisplatin-associated } \\
\text { toxicity and improved the quality of } \\
\text { life. }\end{array}$ & [58] \\
\hline & Oral cancer & $\begin{array}{l}\text { A population-based case-control study } \\
\text { involving } 1830 \text { Caucasian participants } \\
\text { (855 cases and } 975 \text { controls) in during } \\
1984-1985 \text { in the United States. }\end{array}$ & $\begin{array}{l}\text { Reduced oral cancer risk was } \\
\text { associated with glutathione when fruit } \\
\text { and vegetable were commonly } \\
\text { consumed raw. }\end{array}$ & [59] \\
\hline
\end{tabular}




\subsection{Antimicrobial Properties of P. americana}

Currently, there is a growing interest in finding alternatives to the synthetic antimicrobial agents that are commonly used in the food and pharmaceutical industries. This is due to the concerns of the consumers regarding the safety of products containing synthetic chemicals and their associated health risks [174]. Seeds (endocarp) and peels (exocarp) being the by-products of the avocado industry are generally disposed of as wastes [175] and have been investigated for their antimicrobial properties. Most of the studies conducted thus far have noted the antimicrobial activity of the extracts derived from different avocado varieties [104,176-178], while only a few have reported insignificant antimicrobial activity $[101,179]$. The antimicrobial activity of avocado extracts might be influenced by (i) the variety of the avocado, (ii) the parts used for investigation (i.e., exocarp, endocarp, or mesocarp), (iii) the solvent type used for extraction, and iv) the bacterial species examined [104,176]. Raymond and Dykes [176] investigated the antimicrobial activity of ethanolic and aqueous extracts of seeds and peels of three different avocado varieties (Table 6). The authors reported that ethanolic extracts had antibacterial activity against both Gram-positive and Gram-negative bacteria (except for Escherichia coli) ranging from 104.2 to $416.7 \mu \mathrm{g} / \mathrm{mL}$, while aqueous extracts exhibited activity against Listeria monocytogenes and Staphylococcus epidermidis. Rodriguez-Carpena et al. [104] investigated the antibacterial activity of the extracts derived from different avocado parts (peel, seed, and pulp) of a number of varieties against Bacillus cereus, S. aureus, L. monocytogenes, E. coli, Pseudomonas spp., and Yarrowia lipolytica. The highest inhibitory activity against the Gram-positive bacteria- B. cereus and L. monocytogenes was observed, while E. coli was the most sensitive among the tested Gram-negative bacterial species. The authors mentioned that all avocado parts had antimicrobial properties, with pulp (mesocarp) showing the highest activity. In addition, authors reported that the Gram-positive bacteria were more sensitive in comparison to the Gram-negative bacteria [104]. The Gram-negative bacteria have an extra protective outer membrane, which makes them more resistant to antibacterial agents compared to the Gram-positive bacteria $[104,180]$. $\beta$-sitosterol in avocados was also shown to play a key role in strengthening the immune system and the suppression of human immunodeficiency virus and other infections [181]. In particular, it has been found to enhance the proliferation of lymphocytes and natural killer cell activity for invading pathogens [181]. Salinas-Salazar et al. [177] investigated the antimicrobial activity of seed extracts of avocado enriched with acetogenin against L. monocytogenes and reported growth inhibition at $37{ }^{\circ} \mathrm{C}$ and $4{ }^{\circ} \mathrm{C}$ with $\mathrm{MIC}$ (minimum inhibitory concentration) values of 15.6 and $7.8 \mathrm{mg} / \mathrm{L}$, respectively. Acetogenins of avocados are fatty acid derivatives with a long unsaturated aliphatic chain (C19-C23) [182,183]. Owing to the structural similarities between acetogenins and fatty acids, authors hypothesized that acetogenins may penetrate the cell membranes of bacteria and physically disrupt their functionality [177]. Indeed, several compounds might be associated in the antimicrobial activity of avocado extracts. Polyphenols have been previously reported for their antimicrobial properties [184]. However, the contribution of the phenolic compounds toward the antimicrobial activity of avocado extracts needs to be investigated. Rodriguez-Carpena et al. [104] found that avocado pulp extract had a higher antimicrobial activity than peel and seed extracts, despite having lower polyphenol content. Future studies should be conducted to isolate individual phenolic compounds from different parts of avocado and investigate their antimicrobial properties. 
Table 6. Summary of studies that have been conducted that investigated the antimicrobial activity of Persea americana (avocado).

\begin{tabular}{|c|c|c|c|}
\hline Variety/ies & Bacteria & Highlights & Reference \\
\hline Hass Shepard Fuerte & $\begin{array}{l}\text { Listeria monocytogenes } \\
\text { Staphylococcus epidermidis } \\
\text { Staphylococcus aureus } \\
\text { Enterococcus faecalis } \\
\text { Escherichia coli } \\
\text { Salmonella Enteritidis } \\
\text { Citrobacter freundii } \\
\text { Pseudomonas aeruginosa } \\
\text { Salmonella Typhimurium } \\
\text { Enterobacter aerogenes }\end{array}$ & $\begin{array}{l}\text { The antimicrobial activity of peel } \\
\text { and seed extracts was evaluated. } \\
\text { Ethanol extracts showed } \\
\text { antimicrobial activity against both } \\
\text { Gram-positive and Gram-negative } \\
\text { bacteria (except E. coli). } \\
\text { Aqueous extracts had } \\
\text { antimicrobial activity against } L \text {. } \\
\text { monocytogenes and S. epidermidis. }\end{array}$ & [176] \\
\hline $\begin{array}{l}\text { Hass } \\
\text { Fuerte }\end{array}$ & $\begin{array}{l}\text { Bacillus cereus } \\
\text { S. aureus } \\
\text { L. monocytogenes } \\
\text { E. coli } \\
\text { Pseudomonas spp. } \\
\text { Yarrowia lipolytica }\end{array}$ & $\begin{array}{l}\text { All avocado parts had } \\
\text { antimicrobial activities. } \\
\text { Pulp showed the highest } \\
\text { antimicrobial activity. } \\
\text { Gram-positive bacteria were } \\
\text { found to be more sensitive than } \\
\text { Gram-negative bacteria. }\end{array}$ & [104] \\
\hline Hass & L. monocytogenes & $\begin{array}{l}\text { The antilisterial properties of an } \\
\text { enriched acetogenin extract from } \\
\text { avocado seed were determined. } \\
\text { Seeds had higher acetogenin } \\
\text { content than pulp. } \\
\text { The antimicrobial effect was } \\
\text { probably caused by increased } \\
\text { membrane permeability. }\end{array}$ & [177] \\
\hline Lorena Hass & $\begin{array}{l}\text { S. aureus } \\
\text { E. coli }\end{array}$ & $\begin{array}{c}\text { Extracts did not have } \\
\text { antimicrobial activity against } S \text {. } \\
\text { aureus ATCC } 29213 \text { and E. coli } \\
\text { ATCC } 25922\end{array}$ & [179] \\
\hline Hass & $\begin{array}{c}\text { Listeria innocua } \\
\text { E. coli } \\
\text { Lactobacillus sakei } \\
\text { Weissella viridescens } \\
\text { Leuconostoc mesenteroides }\end{array}$ & $\begin{array}{l}\text { Peel and seed extracts did not } \\
\text { present antimicrobial activity } \\
\text { against any bacteria analyzed. }\end{array}$ & [101] \\
\hline
\end{tabular}

\subsection{Anti-Inflammatory Properties of P. americana}

Several studies have investigated the anti-inflammatory properties of avocado via modulation of inflammatory responses (Figure 9, Table 7). The aqueous extract of avocado leaves showed an anti-inflammatory effect in vivo by inhibiting carrageenan-induced rat paw oedema [185]. Persenone A, an active constituent of avocado, reduced inducible nitric oxide synthase (iNOS) and cyclooxygenase-2 (COX-2) in murine macrophages [173]. Similarly, (2R)-(12Z,15Z)-2-hydroxy-4oxoheneicosa-12,15-dien-1-yl acetate, persenone A and B isolated from the avocado fruit, decreased the generation of nitric oxide in mouse macrophages [19]. Avocado oil contains a high amount of oleic acid and essential fatty acids. A study by [186] highlighted the wound-healing properties of avocado fruit oil by increasing collagen synthesis and decreasing inflammation in Wistar rats. They also reported that oleic acid was the predominant unsaturated fatty acid (47.20\%) present in the fruit oil [186].

Inflammation in joints causes damage to the joint cartilage due to degenerative changes leading to a loss of joint function and stability [187]. Even though osteoarthritis (OA) is considered a non-inflammatory disease, recent studies have shown that inflammation is a leading cause for the initiation and continuation of the disease process [188]. Non-pharmacological agents that modulate the expression of pro-inflammatory mediators are highly promising as safe and effective ways to treat 
OA [189]. Avocado-soybean unsaponifiable (ASU) combination represents one of the most commonly used treatments for symptomatic OA [190]. ASU is a combination of avocado oil and soybean oil, which has been accepted as a medication/food supplement in many countries [191]. Three ratios of avocado (A) and soybean (S) unsaponifiable combinations (A:S = 1:2, 2:1, and 1:1) were studied for their anti-inflammatory properties on chondrocyte cells [192]. All the ratios showed significant inhibition compared to the individual extracts on collagenase, stromelysin, interleukin 6 (IL-6), interleukin 8 (IL-8), and prostaglandin $E_{2}$ (PGE2) release. In particular, 1:2 was found to be the most effective combination that exhibited chondroprotective effects in vivo by stimulating glycosaminoglycan and hydroxyproline synthesis and inhibiting the production of hydroxyproline in the granulomatous tissue [192]. In another study, the unsaponifiables of avocado alone indicated a significant chondroprotective effect [193]. Several preclinical and clinical studies conducted in the last few decades have revealed the modulation of different pathways and molecular targets associated with OA pathogenesis by ASU [194]. For instance, the anti-OA properties of ASU are mediated via the suppression of critical regulators of the inflammatory response such as iNOS/COX-2, and PGE-2 [195], and the reduction of catabolic enzymes (matrix metalloproteinases-3 and -13) and [190,196]. Gabay et al. [190] demonstrated the inactivation of the mitogen-activated protein kinases such as the extracellular signal-regulated kinase (ERK 1/2) and NF- $\kappa$ B as the molecular mechanism of action for the anti-inflammatory effects of ASU. A recent study showed the potential bone repair properties of ASU by the modulation of molecular targets Rankl and Il1 $\beta$, RANKL, and TRAP using a rat model [197]. Sterols, the major bioactive components of ASU, have also shown anti-inflammatory activity in articular chondrocytes [198].

A significant reduction of articular cartilage erosion and synovial hemorrhage compared to placebo was observed in horses using ASU extracts [199]. However, the extracts did not reduce signs of pain or lameness in horses. In humans, NSAID (nonsteroidal anti-inflammatory drugs) consumption was reduced in patients with lower limb OA after six weeks of ASU consumption [200]. Furthermore, ASU significantly reduced the progression of joint space loss in patients with hip OA [201]. Another study by Maheu et al. [202] demonstrated slow radiographic progression in hip OA using ASU treatment. They also reported that the treatment was well tolerated by patients, even though the clinical outcome did not change. Interestingly, a recent study showed that the intake of ASU extract decreased the pain symptoms and an improved the quality of life in patients with OA of the temporomandibular joint [203].

Other studies have combined ASU with bioactive compounds such as epigallocatechin gallate (EGCG), and $\alpha$-lipoic acid (LA) $[189,204,205]$. Interestingly, contrary to previous research, Heinecke et al. [204] reported a slight inhibition of COX-2 expression and $\mathrm{PGE}_{2}$ production in activated chondrocytes. However, when ASU was combined with EGCG, both mediators were more significantly inhibited than their mono treatments [204]. Another study by Ownby et al. demonstrated that this combination inhibited the gene expression of interleukin-1 beta (IL-1 $\beta$ ), tumor necrosis factor- $\alpha$ (TNF- $\alpha$ ), IL-6, COX-2, and IL-8 in activated chondrocytes [189]. The combination of ASU with LA showed a more significant suppression of $\mathrm{PGE}_{2}$ production in activated chondrocytes than ASU or LA alone [205]. 
Table 7. Anti-inflammatory properties of Persea americana (avocado) extracts, compounds, and combinations.

\begin{tabular}{|c|c|c|}
\hline Extracts and Compounds & $\begin{array}{c}\text { Key Findings and Molecular Mechanism } \\
\text { of Action }\end{array}$ & Reference \\
\hline Leaf aqueous extract & $\begin{array}{l}\text { Reduced carrageenan-induced rat paw } \\
\text { oedema. }\end{array}$ & [185] \\
\hline Persenone A & $\begin{array}{l}\text { Reduced inducible nitric oxide synthase } \\
\text { (iNOS) and cyclooxygenase- } 2 \text { (COX-2) in } \\
\text { activated murine macrophages. }\end{array}$ & [173] \\
\hline Avacado oil & $\begin{array}{l}\text { Promoted increased collagen synthesis and } \\
\text { decreased inflammation in wound healing } \\
\text { on incisional and excisional cutaneous } \\
\text { wound models in Wistar rats. }\end{array}$ & [186] \\
\hline $\begin{array}{l}(2 R)-(12 Z, 15 Z)-2 \text {-hydroxy-4-oxoheneicosa- } \\
\text { 12,15-dien-1-yl acetate, persenone A and B }\end{array}$ & $\begin{array}{l}\text { Decreased nitric oxide generation in } \\
\text { activated mouse macrophages. }\end{array}$ & [19] \\
\hline \multirow{8}{*}{ Avocado-Soybean Unsaponifiables (ASU) } & $\begin{array}{l}\text { Inhibited collagenase, stromelysin, IL-6, } \\
\text { IL-8, and prostaglandin } E_{2} \text { (PGE2) release in } \\
\text { activated human articular chondrocytes. }\end{array}$ & [192] \\
\hline & $\begin{array}{l}\text { Stimulated glycosaminoglycan and } \\
\text { hydroxyproline synthesis, and inhibited the } \\
\text { production of hydroxyproline in the } \\
\text { granulomatous tissue of mice model. }\end{array}$ & [193] \\
\hline & $\begin{array}{l}\text { Suppressed critical regulators of the } \\
\text { inflammatory response such as PGE- } 2 \text { and } \\
\text { COX-2 in activated human chondrocytes. }\end{array}$ & [195] \\
\hline & $\begin{array}{c}\text { Decreased catabolic enzymes, matrix } \\
\text { metalloproteinases- } 3 \text { and }-13 \text { expressions } \\
\text { via inactivating the expression of MAPKs } \\
(\text { ERK } 1 / 2) \text { and nuclear factor kappa-B } \\
(\mathrm{NF}-\kappa \mathrm{B}) \text { in activated mouse or human } \\
\text { chondrocytes. }\end{array}$ & [190] \\
\hline & $\begin{array}{l}\text { Reduced pro-inflammatory cytokines such } \\
\text { as TNF- } \alpha, \text { IL-1 } \beta \text {, and iNOS expression in } \\
\text { activated chondrocytes and THP-1 } \\
\text { monocyte and macrophages. }\end{array}$ & [196] \\
\hline & $\begin{array}{c}\text { Exhibited a promising result on the bone } \\
\text { repair by modulating the molecular targets } \\
\text { of Rankl and Il1 } \beta, \text { RANKL, TRAP in rat } \\
\text { model. }\end{array}$ & [197] \\
\hline & $\begin{array}{l}\text { Decreased pain symptoms in patients with } \\
\text { osteoarthritis of the temporomandibular } \\
\text { joint. }\end{array}$ & [203] \\
\hline & $\begin{array}{c}\text { Modulated the expression of TGF- } \beta 1 \text {, } \\
\text { TGF- } \beta 2 \text {, and BMP- } 2 \text { in activated human } \\
\text { periodontal ligament and human alveolar } \\
\text { bone cells. }\end{array}$ & [206] \\
\hline \multirow{2}{*}{ ASU + Epigallocatechin gallate } & $\begin{array}{c}\text { Inhibited COX-2 expression and } \mathrm{PGE}_{2} \\
\text { production in activated equine } \\
\text { chondrocytes. }\end{array}$ & [204] \\
\hline & $\begin{array}{c}\text { Inhibited the gene expression of IL- } 1 \beta \text {, } \\
\text { TNF- } \alpha \text {, IL-6, COX-2, and IL- } 8 \text { in activated } \\
\text { equine chondrocytes. }\end{array}$ & [189] \\
\hline
\end{tabular}


The implementation of ASU in the treatment of other inflammatory diseases has also been explored. In particular, ASU has shown efficacy against periodontal disease by modulating the expression of transforming growth factor beta 1 (TGF- $\beta 1$ ), TGF- $\beta 2$, and bone morphogenetic protein 2 (BMP-2) [206]. Additionally, a recent study demonstrated that ASU can repair periodontal disease within seven days [207]. These results underline the significant anti-inflammatory properties of avocado mediated via multiple signal transduction pathways and their role in the potential treatment of various inflammatory diseases.

\subsection{Effect of P. americana on Cardiovascular Health and Diabetes}

Clinical have shown a positive effect on cardiovascular health and lipid profiles with the presence of avocado in the diet $[65,208]$. It has been observed that the intake of avocado in a balanced diet had a great impact on preventing cardiovascular diseases as a result of the low cholesterol levels. Grant in 1959 [209] conducted the first avocado clinical trial where 0.5 to 1.5 avocados were incorporated in the diet of 16 male patients, and showed a significant decrease or the same total serum cholesterol level with no increase in weight. In particular, avocado phytosterols were found to inhibit cholesterol absorption and synthesis by mimicking its molecular structure, which resulted in lowered total cholesterol levels in the body [210]. A randomized, controlled trial was conducted on 45 obese patients where the patients were categorized into three major groups-(i) moderate-fat diet, (ii) low-fat diet, and (iii) moderate-fat diet with the incorporation of one avocado (AV). A major decrease in the total cholesterol levels in all the groups was observed from the baseline, while the AV group had a greater reduction in LDL-C and non-high-density lipoprotein (non-HDL) [67]. According to the results from the National Health and Nutrition Examination Survey (NHANES), people who consumed avocados had an improved diet quality due to increased vegetable intake and reduced sugar consumption [211]. Therefore, vascular damage and heart diseases can be reduced to a great extent by the inclusion of avocados in a diet [211]. In another study, the inclusion of avocado in a meal increased satisfaction with a decrease in actual eating in obese adults, which indirectly had a positive effect on the body mass index (BMI) and reduced the chances of cardiovascular diseases [212]. An increase in the satisfaction (by 23\%), decrease in eating (by 28\%), and blood insulin were observed in comparison to the control group [212]. A systematic review was conducted by Silva Caldas et al. [213] to study the effects of avocado on the cardiovascular health of adults, and after including eight articles from the initial 234 studies, they concluded that the presence of MUFA, specifically oleic fatty acid in avocado has been linked with its cardioprotective effects.

A study done by Carvajal-Zarrabal et al. [214] found out that avocado oil had a significant contribution toward the metabolic syndrome, as it reduced the inflammatory events and exhibited positive results in the biochemical indicators when they administered avocado oil in 25 rats divided into various groups such as a control group, a basic diet group with $30 \%$ sucrose, and a basic diet plus olive oil and avocado oil. Extensive biochemical markers were studied, and the presence of avocado oil seemed to have reduced the triglycerides and LDL levels, which reduced the cardiovascular risks [214]. Cohort studies performed recently on the BMI of individuals after the intake of avocados showed a considerable reduction in weight gain compared to the control, which consecutively lowered various cardiovascular problems associated with obesity [215]. Another report in 2018 [216] analyzed studies on the intake of avocado and cardiovascular risks from MEDLINE, Cochrane Central, and the Commonwealth Agricultural Bureau, and found a significant increase in HDL cholesterol concentration with heterogeneity associated with avocado intake. However, no significant reduction in LDL cholesterol and serum total cholesterol was mentioned in this report [216].

The indigestible carbohydrates abundantly found in avocado are reported to prevent diabetes and regulate blood cholesterol [217]. The glycemic index can be defined as a comparative ranking of carbohydrate in foods according to their effect on blood sugar levels [218]. Despite its carbohydrate content, the glycemic index rating of avocado is quite low. In rats, various aqueous concentrations of $P$. americana seed extract exhibited hypoglycemic and antihyperglycemic effects by significantly 
decreasing the blood glucose levels [219], highlighting its potential in the management of diabetes mellitus. Another study conducted to investigate the effect of avocado paste on rats with a hypercholesterolemic diet with high fructose showed lower levels of blood sugar and significant reduction of fat accumulation in the liver, which was attributed to the presence of bioactive compounds (polyphenols, fiber, and carotenoids) [220]. Investigation on the inhibitory effects of phenolic extract from the avocado pulp, leaves, and seed on various type 2 diabetes enzymes ( $\alpha$-amylase and $\alpha$-glucosidase) was also performed [221]. The peel extract exhibited the highest inhibition against $\alpha$-amylase and $\alpha$-glucosidase, while the leaf extract significantly inhibited the $\alpha$-glucosidase. In a recent study, the glycemic and lipoprotein profiles of the obese middle-aged adult were improved when the carbohydrate was replaced with avocados in a meal [222]. The participants were divided into three different groups: control group ( $0 \mathrm{~g}$ ), half avocado (half- $\mathrm{A}, 68 \mathrm{~g}$ ), and whole avocado (whole-A, $136 \mathrm{~g}$ ). In comparison to the control group, the half-A and whole-A group showed decreased glycemic and insulinemic response over $6 \mathrm{~h}$ [222].

\subsection{Bioavailability and Pharmacokinetic of Compounds from P. americana}

Avocado is a relatively unique fruit, containing high levels of water and fat-soluble vitamins, plant sterols, MUFA, and phytochemicals [223]. Avocado has been shown to improve the absorption of nutrients when used in combination with other foods and supplements [224]; however, research on the pharmacokinetics of the avocado components alone is limited.

Vitamin A is fat-soluble in nature and present in many foods as retinol and in its provitamin A form (carotenes). In particular, liver, fish, and cheese are rich sources of vitamin A. Carotenes (provitamin A) are converted to vitamin A in the body. However, plant-based foods typically present a challenging matrix for the utilization of vitamin $\mathrm{A}$, hindering the absorption and conversion of provitamin A to vitamin A [225]. Many commonly consumed plant-based foods contain higher levels of provitamin A such as sweet potato $(709 \mu \mathrm{g} / 100 \mathrm{~g})$, carrots $(835 \mu \mathrm{g} / 100 \mathrm{~g})$, and spinach $(469 \mu \mathrm{g} / 100 \mathrm{~g})$, especially compared to avocado $(7 \mu \mathrm{g} / 100 \mathrm{~g})$ [223]. Nevertheless, the levels of vitamins in the food are trivial if not absorbed and converted to their active chemical forms for the body to utilize. The absorption of provitamin A from plant sources is typically poor. In an in vitro digestion model, the accessibility of $\beta$-carotene in raw carrots was $1-3 \%$ and lycopene was $<1 \%$ [226]. The consumption of lipid-rich food has been shown to improve the absorption of fat-soluble vitamins, including vitamin A [227]. The presence of soluble fats during digestion facilitates the formations of mixed micelles, which facilitate absorption [228].

The absorptions of provitamin A including $\beta$-carotene, $\alpha$-carotene, $\beta$-cryptoxanthin, lutein, and zeaxanthin were enhanced when co-consumed with avocado. This can perhaps be attributed to the high MUFA content of avocado. In salsa, the absorption of lycopene and $\beta$-carotene was increased by 4.4 and 2.6 times respectively when avocado was added. In salad $(150 \mathrm{~g})$, the addition of avocado $(24 \mathrm{~g})$ increased the absorption of $\alpha$ and $\beta$-carotene and lutein by 7.2, 15.3, and 5.1 times, respectively [224]. In addition to the improved absorption, avocados were shown to enhance the utilization of provitamin A by increasing the conversion rate to vitamin A in participants with low conversion efficacy [229]. The enhanced absorption of provitamin A has been attributed to the improved formation of mixed micelles in the lumen, increasing solubility and facilitating uptake by enterocytes. Improved vitamin A uptake has been observed with other high lipid foods such as eggs and oil [230]. Likewise, the consumption of salad rich in carotenes, with canola oil, resulted in significantly higher carotene concentrations in chylomicrons [231]. As avocado is a rich source of fat and high in monosaturated fatty acids, it presents an alternative from sources high in unsaturated fats.

Avocado is the most concentrated source of $\beta$-sitosterol in commonly consumed Western fruits [79]. Plant sterols share similar chemical structures with cholesterol; however, they are poorly absorbed compared to cholesterol, (with about $10 \%$ systematically absorbed compared to $50-60 \%$ for cholesterol) [232]. Similar to other lipophilic compounds, phytosterols are incorporated into mixed micelles before being taken up by enterocytes [233]. Plant steroids may assist in lowering cholesterol 
absorption by acting as a competitive inhibitor. Interestingly, plant sterols have also been observed to lower dietary carotene plasma levels by 10-20\% [234]. As avocados have been reported to increase carotene absorption and subsequent plasma levels, this effect may be overcome by the benefit of the other lipid components present. Due to its unique fruit matrix high in plant sterols and MUFA, avocados may provide an enhanced absorption of lipophilic compounds compared to other fruits and vegetables. As established for vitamin A and carotene, it is likely that the absorption of other lipophilic compounds may similarly be enhanced by consumption with avocado. Within avocado, this may apply to vitamin E, vitamin K, chlorophylls, and phytochemicals such as acetogenins. Further pharmacokinetic research is necessary to determine if the absorption of other lipophilic compounds is enhanced in combination with avocado. The current literature does not provide any information regarding the effect of avocado matrix on the absorption of water-soluble vitamins and phytochemicals. Moreover, further pharmacokinetic research should be directed to understand the bioavailability of pharmaceutically promising phytochemicals such as acetogenins from avocado.

\section{Conclusions and Future Direction}

Several preclinical studies performed in the last few decades lay emphasis on the unique nutritional and phytochemical composition of avocado and their potential in the treatment and prevention of different diseases. Some studies have underlined its importance as the source of lead molecules for drug discovery due to the abundance of novel chemical skeletons. The cumulative effects of avocado components in the prevention and treatment of oxidative stress and age-related degenerative diseases are also indicated in a few studies. However, more comprehensive in vitro, in vivo, and clinical investigations are fundamental to significantly expand the understanding of the molecular mechanisms of action of its phytochemicals for developing subsequent therapeutic and nutritional interventions against cancer, diabetes, inflammatory, microbial, and cardiovascular diseases. Interestingly, despite its popularity as a "superfood", clinical studies evaluating the therapeutic potential of avocado for the prevention and management of different ailments are limited in the literature. More investigations to understand the bioavailability and pharmacokinetics of avocado phytochemicals and antioxidants are also crucial to determine their clinical efficacy and potential toxicity. Regardless of the recent food trends and marketing gimmicks of "superfoods", variety is fundamental for a balanced healthy diet. As many studies have revealed the complex synergistic interactions among different phytochemicals present in food matrices, studies to understand the possible synergy between bioactive compounds from avocado and other fruit and vegetables will help formulate diet-based preventive strategies for many diseases. A few reports have indicated the role of avocado in improving the bioavailability of nutrients from other plant-based foods. Therefore, consuming avocados with other fruit and vegetables as a part of the diet can be beneficial to human health.

Author Contributions: D.J.B., conceptualization, writing, review and editing, supervision; M.A.A., conceptualization and writing; S.P., conceptualization and writing; M.L., conceptualization and writing; A.B., conceptualization and writing; O.A.D., conceptualization and writing; M.S.B. conceptualization and writing; C.G.L., writing, review and editing; K.P., conceptualization, writing, review and editing.

Funding: This research received no external funding.

Conflicts of Interest: As a medical research institute, the NICM Health Research Institute receives research grants and donations from foundations, universities, government agencies, individuals, and industry. Sponsors and donors also provide untied funding for work to advance the vision and mission of the institute. The authors declare no conflict of interest.

\section{References}

1. Bergh, B.; Ellstrand, N. Taxonomy of the avocado. Calif. Avocado Soc. Yearb. 1986, 70, 135-145.

2. Segovia, F.J.; Hidalgo, G.I.; Villasante, J.; Ramis, X.; Almajano, M.P. Avocado seed: A comparative study of antioxidant content and capacity in protecting oil models from oxidation. Molecules 2018, 23, 2421. [CrossRef] 
3. Cowan, A.K.; Wolstenholme, B.N. Avocado. In Encyclopedia of Food and Health; Caballero, B., Finglas, P.M., Toldrá, F., Eds.; Academic Press: Oxford, UK, 2016; pp. 294-300.

4. Taulavuori, K.; Julkunen-Tiitto, R.; Hyöky, V.; Taulavuori, E. Blue Mood for Superfood. Nat. Prod. Commun. 2013, 8, 1934578X1300800627. [CrossRef]

5. Rahmani, G.; Martin-Smith, J.; Sullivan, P. The Avocado Hand. Ir. Med. J. 2017, 110, 658. [PubMed]

6. Agricultural Marketing Resource Center. Avocados; Iowa State University in Ames: Ames, IA, USA, 2018.

7. Combined Chemical Dictionary 23.1; CRC Press, Taylor \& Francis Group: Boca Raton, FL, USA, 2019; Available online: http://ccd.chemnetbase.com/faces/chemical/ChemicalSearch.xhtml;jsessionid= 7B7405700267BD91E58E52C6333BF438 (accessed on 1 August 2019).

8. The Human Metabolome Database. 2019. Available online: http://www.hmdb.ca/ (accessed on 1 August 2019).

9. Yasir, M.; Das, S.; Kharya, M.D. The phytochemical and pharmacological profile of Persea americana Mill. Pharmacogn. Rev. 2010, 4, 77-84. [CrossRef] [PubMed]

10. Wu, Y.H.; Tseng, C.K.; Wu, H.C.; Wei, C.K.; Lin, C.K.; Chen, I.S.; Chang, H.S.; Lee, J.C. Avocado (Persea americana) fruit extract (2R,4R)-1,2,4-trihydroxyheptadec-16-yne inhibits dengue virus replication via upregulation of NF-kappaB-dependent induction of antiviral interferon responses. Sci. Rep. 2019, 9, 423. [CrossRef] [PubMed]

11. Adikaram, N.K.B.; Ewing, D.F.; Karunaratne, A.M.; Wijeratne, E.M.K. Antifungal Compounds from Immature Avocado Fruit Peel. Phytochemistry 1992, 31, 93-96. [CrossRef]

12. Abe, F.; Nagafuji, S.; Okawa, M.; Kinjo, J.; Akahane, H.; Ogura, T.; Martinez-Alfaro, M.A.; Reyes-Chilpa, R. Trypanocidal Constituents in Plants 5. Evaluation of some mexican plants for their trypanocidal activity and active constituents in the seeds of Persea americana. Biol. Pharm. Bull. 2005, 28, 1314-1317. [CrossRef] [PubMed]

13. Lu, Y.C.; Chang, H.S.; Peng, C.F.; Lin, C.H.; Chen, I.S. Secondary metabolites from the unripe pulp of Persea americana and their antimycobacterial activities. Food Chem. 2012, 135, 2904-2909. [CrossRef] [PubMed]

14. Domergue, F.; Helms, G.L.; Prusky, D.; Browse, J. Antifungal compounds from idioblast cells isolated from avocado fruits. Phytochemistry 2000, 54, 183-189. [CrossRef]

15. Lee, T.-H.; Tsai, Y.-F.; Huang, T.-T.; Chen, P.-Y.; Liang, W.-L.; Lee, C.-K. Heptadecanols from the leaves of Persea americana var. americana. Food Chem. 2012, 132, 921-924. [CrossRef]

16. Bull, S.D.; Carman, R.M. Synthesis of the Avocado Antifungal,(Z, Z)-2-Hydroxy-4-oxohenicosa-12, 15-dien-1-yl Acetate. Aust. J. Chem. 1994, 47, 1661-1672. [CrossRef]

17. Rodriguez-Saona, C.; Millar, J.G.; Trumble, J.T. Isolation, Identification, and Biological Activity of Isopersin, a New Compound from Avocado Idioblast Oil Cells. J. Nat. Prod. 1998, 61, 1168-1170. [CrossRef] [PubMed]

18. Kashman, Y.; Néeman, I.; Lifshitz, A. New compounds from avocado pear. Tetrahedron 1969, 25, 4617-4631. [CrossRef]

19. Kim, O.K.; Murakami, A.; Nakamura, Y.; Takeda, N.; Yoshizumi, H.; Ohigashi, H. Novel Nitric Oxide and Superoxide Generation Inhibitors, Persenone A and B, from Avocado Fruit. J. Agric. Food Chem. 2000, 48, 1557-1563. [CrossRef]

20. Chen, C.-Y.; Chen, C.-H.; Wong, C.-H.; Liu, Y.-W.; Lin, Y.-S.; Wang, Y.-D.; Hsui, Y.-R. Cytotoxic Constituents of the Stems of Cinnamomum subavenium. J. Nat. Prod. 2007, 70, 103-106. [CrossRef] [PubMed]

21. Oberlies, N.H.; Rogers, L.L.; Martin, J.M.; McLaughlin, J.L. Cytotoxic and insecticidal constituents of the unripe fruit of Persea americana. J. Nat. Prod. 1998, 61, 781-785. [CrossRef]

22. Ortega-Arellano, H.F.; Jimenez-Del-Rio, M.; Velez-Pardo, C. Neuroprotective effects of methanolic extract of avocado Persea americana (var. Colinred) peel on paraquat-induced locomotor impairment, lipid peroxidation and shortage of life span in transgenic knockdown parkin drosophila melanogaster. Neurochem. Res. 2019, 44, 1986-1998. [CrossRef]

23. Ramos-Jerz Mdel, R.; Villanueva, S.; Jerz, G.; Winterhalter, P.; Deters, A.M. Persea americana Mill. Seed: Fractionation, Characterization, and Effects on Human Keratinocytes and Fibroblasts. Evid. Based Complement. Altern. Med. 2013, 2013, 391247. [CrossRef]

24. Lu, Q.Y.; Arteaga, J.R.; Zhang, Q.; Huerta, S.; Go, V.L.; Heber, D. Inhibition of prostate cancer cell growth by an avocado extract: Role of lipid-soluble bioactive substances. J. Nutr. Biochem. 2005, 16, 23-30. [CrossRef] 
25. Naveed, M.; Hejazi, V.; Abbas, M.; Kamboh, A.A.; Khan, G.J.; Shumzaid, M.; Ahmad, F.; Babazadeh, D.; FangFang, X.; Modarresi-Ghazani, F.; et al. Chlorogenic acid (CGA): A pharmacological review and call for further research. Biomed. Pharmacother. 2018, 97, 67-74. [CrossRef] [PubMed]

26. Bhattacharyya, S.S.; Paul, S.; Dutta, S.; Boujedaini, N.; Khuda-Bukhsh, A.R. Anti-oncogenic potentials of a plant coumarin (7-hydroxy-6-methoxy coumarin) against 7,12-dimethylbenz [a] anthracene-induced skin papilloma in mice: The possible role of several key signal proteins. Chin. J. Integr. Med. 2010, 8, 645-654. [CrossRef] [PubMed]

27. Martin, C.; Kunesch, G.; Martin-Tanguy, J.; Negrel, J.; Paynot, M.; Carre, M. Effect of cinnamoyl putrescines on in vitro cell multiplication and differentiation of tobacco explants. Plant Cell. Rep. 1985, 4, 158-160. [CrossRef] [PubMed]

28. Santana, I.; Castelo-Branco, V.N.; Guimarães, B.M.; Silva, L.d.O.; Peixoto, V.O.D.S.; Cabral, L.M.C.; Freitas, S.P.; Torres, A.G. Hass avocado (Persea americana Mill.) oil enriched in phenolic compounds and tocopherols by expeller-pressing the unpeeled microwave dried fruit. Food Chem. 2019, 286, 354-361. [CrossRef] [PubMed]

29. Gross, J.; Gabai, M.; Lifshitz, A.; Sklarz, B. Structures of some carotenoids from the pulp of Persea americana. Phytochemistry 1974, 13, 1917-1921. [CrossRef]

30. Gross, J.; Gabai, M.; Lifshitz, A.; Sklarz, B. Carotenoids in pulp, peel and leaves of Persea americana. Phytochemistry 1973, 12, 2259-2263. [CrossRef]

31. Rodriguez-Saona, C.R.; Maynard, D.F.; Phillips, S.; Trumble, J.T. Alkylfurans: Effects of Alkyl Side-Chain Length on Insecticidal Activity. J. Nat. Prod. 1999, 62, 191-193. [CrossRef]

32. Rodriguez-Saona, C.; Millar, J.G.; Maynard, D.F.; Trumble, J.T. Novel Antifeedant and Insecticidal Compounds from Avocado Idioblast Cell Oil. J. Chem. Ecol. 1998, 24, 867-889. [CrossRef]

33. Fraga, B.M.; Terrero, D. Alkene- $\gamma$-lactones and avocadofurans from Persea indica: A revision of the structure of majorenolide and related lactones. Phytochemistry 1996, 41, 229-232. [CrossRef]

34. Rosenblat, G.; Kagan, H.M.; Shah, M.A.; Spiteller, G.; Neeman, I. Chemical characterization of lysyl oxidase inhibitor from avocado seed oil. J. Am. Oil Chem. Soc. 1995, 72, 225-229. [CrossRef]

35. Zaki, A.; Zentmyer, G.; Pettus, J.; Sills, J.; Keen, N.; Sing, V. Borbonol from Persea spp.-chemical properties and antifungal activity against Phytophthora cinnamomi. Physiol. Plant Pathol. 1980, 16, 205-212. [CrossRef]

36. Falodun, A.; Engel, N.; Kragl, U.; Nebe, B.; Langer, P. Novel anticancer alkene lactone from Persea americana. Pharm. Biol. 2013, 51, 700-706. [CrossRef]

37. Chen, C.-Y.; Chen, C.-H.; Lo, Y.-C.; Wu, B.-N.; Wang, H.-M.; Lo, W.-L.; Yen, C.-M.; Lin, R.-J. Anticancer Activity of Isoobtusilactone A from Cinnamomum kotoense: Involvement of Apoptosis, Cell-Cycle Dysregulation, Mitochondria Regulation, and Reactive Oxygen Species. J. Nat. Prod. 2008, 71, 933-940. [CrossRef]

38. Rodriguez-Saona, C.; Maynard, D.F.; Phillips, S.; Trumble, J.T. Avocadofurans and their tetrahydrofuran analogues: Comparison of growth inhibitory and insecticidal activity. J. Agric. Food Chem. 2000, 48, 3642-3645. [CrossRef]

39. Fraga, B.M.; González-Coloma, A.; Gutiérrez, C.; Terrero, D. Insect Antifeedant Isoryanodane Diterpenes from Persea indica. J. Nat. Prod. 1997, 60, 880-883. [CrossRef]

40. Han, A.; Tao, Y.; Reisman, S.E. 16-Step Synthesis of the Isoryanodane Diterpene (+)-Perseanol. ChemRxiv. Preprint. 2019, in press. [CrossRef]

41. Gonzalez-Coloma, A.; Hernandez, M.G.; Perales, A.; Fraga, B.M. Chemical ecology of canarian laurel forest: Toxic diterpenes from Persea indica (Lauraceae). J. Chem. Ecol. 1990, 16, 2723-2733. [CrossRef]

42. Fraga, B.M.; Terrero, D.; Gutiérrez, C.; González-Coloma, A. Minor diterpenes from Persea indica: Their antifeedant activity. Phytochemistry 2001, 56, 315-320. [CrossRef]

43. Gonzlez-Coloma, A.; Cabrera, R.; Socorro Monzón, A.R.; Frag, B.M. Persea indica as a natural source of the insecticide ryanodol. Phytochemistry 1993, 34, 397-400. [CrossRef]

44. Hann, R.M.; Hudson, C.S. Proof of the Structure and Configuration of Perseulose (L-Galaheptulose). J. Am. Chem. Soc. 1939, 61, 336-340. [CrossRef]

45. Sephton, H.H.; Richtmyer, N.K. The isolation of D-erythro-L-galacto-nonulose from the avocado, together with its synthesis and proof of structure through reduction to D-arabino-D-manno-nonitol and D-arabino-D-gluco-nonitol. Carbohyd. Res. 1966, 2, 289-300. [CrossRef]

46. Sephton, H.H.; Richtmyer, N.K. Isolation of D-erythro-L-gluco-Nonulose from the Avocado1. J. Org. Chem. 1963, 28, 2388-2390. [CrossRef] 
47. Charlson, A.J.; Richtmyer, N.K. The Isolation of an octulose and an octitol from natural sources: D-glycero-D-manno-Octulose and D-erythro-D-galacto-octitol from the avocado and D-glycero-D-manno-octulose from Sedum species1,2. J. Am. Chem. Soc. 1960, 82, 3428-3434. [CrossRef]

48. Ian-Lih, T.; Chih-Feng, H.; Chang-Yih, D.; Ih-Sheng, C. Cytotoxic neolignans from Persea obovatifolia. Phytochemistry 1996, 43, 1261-1263. [CrossRef]

49. Xia, Y.; Wang, W. Asymmetric synthesis of machilin C and its analogue. Chem. Pap. 2010, 64, 630-636. [CrossRef]

50. Ward, R.S. Lignans neolignans, and related compounds. Nat. Prod. Rep. 1993, 10, 1-28. [CrossRef]

51. Tsai, I.-L.; Hsieh, C.-F.; Duh, C.-Y.; Chen, I.-S. Further study on the chemical constituents and their cytotoxicity from the leaves of Persea obovatifolia. Chin. Pharm. J. 1999, 51, 335-346.

52. Tsai, I.-L.; Hsieh, C.-F.; Duh, C.-Y. Additional cytotoxic neolignans from Persea obovatifolia. Phytochemistry 1998, 48, 1371-1375. [CrossRef]

53. Sepulveda-Boza, S.; Delhvi, S.; Cassels, B.K. An aryltetralin lignan from Persea lingue. Phytochemistry 1990, 29, 2357-2358. [CrossRef]

54. Chang, C.-F.; Isogai, A.; Kamikado, T.; Murakoshi, S.; Sakurai, A.; Tamura, S. Isolation and structure elucidation of growth inhibitors for silkworm larvae from avocado leaves. Agric. Biol. Chem. 1975, 39, 1167-1168. [CrossRef]

55. El Kharrassi, Y.; Samadi, M.; Lopez, T.; Nury, T.; El Kebbaj, R.; Andreoletti, P.; El Hajj, H.I.; Vamecq, J.; Moustaid, K.; Latruffe, N.; et al. Biological activities of Schottenol and Spinasterol, two natural phytosterols present in argan oil and in cactus pear seed oil, on murine miroglial BV2 cells. Biochem. Biophys. Res. Commun. 2014, 446, 798-804. [CrossRef] [PubMed]

56. Ohsaki, A.; Kubota, T.; Asaka, Y. Perseapicroside A, hexanorcucurbitacin-type glucopyranoside from Persea mexicana. Phytochemistry 1990, 29, 1330-1332. [CrossRef]

57. Cascinu, S.; Catalano, V.; Cordella, L.; Labianca, R.; Giordani, P.; Baldelli, A.M.; Beretta, G.D.; Ubiali, E.; Catalano, G. Neuroprotective effect of reduced glutathione on oxaliplatin-based chemotherapy in advanced colorectal cancer: A randomized, double-blind, placebo-controlled trial. J. Clin. Oncol. 2002, 20, 3478-3483. [CrossRef] [PubMed]

58. Smyth, J.F.; Bowman, A.; Perren, T.; Wilkinson, P.; Prescott, R.J.; Quinn, K.J.; Tedeschi, M. Glutathione reduces the toxicity and improves quality of life of women diagnosed with ovarian cancer treated with cisplatin: Results of a double-blind, randomised trial. Ann. Oncol. 1997, 8, 569-573. [CrossRef] [PubMed]

59. Flagg, E.W.; Coates, R.J.; Jones, D.P.; Byers, T.E.; Greenberg, R.S.; Gridley, G.; McLaughlin, J.K.; Blot, W.J.; Haber, M.; Preston-Martin, S.; et al. Dietary Glutathione Intake and the Risk of Oral and Pharyngeal Cancer. Am. J. Epidemiol. 1994, 139, 453-465. [CrossRef] [PubMed]

60. Choudhury, S.; Vajczikova, I. Variations in the essential oil composition of Persea bombycina (King ex Hook. f.) Kost and its effect on muga silkworm (Antheraea assama Ww) - A new report. Indian J. Chem. B 2003, $42 B, 641-647$.

61. U.S. Department of Agriculture, Agricultural Research Service. Avocados, Raw, California. FoodData Central. 2019. Available online: https://fdc.nal.usda.gov/fdc-app.html\#/food-details/171706/nutrients (accessed on 22 September 2019).

62. Duarte, P.F.; Chaves, M.A.; Borges, C.D.; Mendonça, C.R.B. Avocado: Characteristics, health benefits and uses. Cienc. Rural 2016, 46, 747-754. [CrossRef]

63. Duester, K.C. Avocados a look beyond basic nutrition for one of nature's whole foods. Nutr. Today 2000, 35, 151-157. [CrossRef]

64. Bao, J.; Atkinson, F.; Petocz, P.; Willett, W.C.; Brand-Miller, J.C. Prediction of postprandial glycemia and insulinemia in lean, young, healthy adults: Glycemic load compared with carbohydrate content alone. Am. J. Clin. Nutr. 2011, 93, 984-996. [CrossRef]

65. Dreher, M.L.; Davenport, A.J. Hass avocado composition and potential health effects. Crit. Rev. Food Sci. Nutr. 2013, 53, 738-750. [CrossRef]

66. Landahl, S.; Meyer, M.D.; Terry, L.A. Spatial and temporal analysis of textural and biochemical changes of imported avocado cv. Hass during fruit ripening. J. Agric. Food Chem. 2009, 57, 7039-7047. [CrossRef] [PubMed] 
67. Wang, L.; Bordi, P.L.; Fleming, J.A.; Hill, A.M.; Kris-Etherton, P.M. Effect of a moderate fat diet with and without avocados on lipoprotein particle number, size and subclasses in overweight and obese adults: A randomized, controlled trial. J. Am. Heart Assoc. 2015, 4, e001355. [CrossRef] [PubMed]

68. Ranade, S.S.; Thiagarajan, P. A review on Persea americana Mill.(avocado)-its fruits and oil. Int. J. Pharmtech Res. 2015, 8, 72-77.

69. de Melo, M.F.F.T.; Pereira, D.E.; Moura, R.d.L.; da Silva, E.B.; de Melo, F.A.L.T.; Dias, C.d.C.Q.; Silva, M.d.C.A.; de Oliveira, M.E.G.; Viera, V.B.; Pintado, M.M.E.; et al. Maternal supplementation with avocado (Persea americana Mill.) pulp and oil alters reflex maturation, physical development, and offspring memory in rats. Front. Neurosci. 2019, 13, 9. [CrossRef] [PubMed]

70. Carvalho, C.P.; Bernal, E.J.; Velásquez, M.A.; Cartagena, V.J.R. Fatty acid content of avocados (Persea americana Mill. cv. Hass) in relation to orchard altitude and fruit maturity stage. Agron. Colomb. 2015, 33, 220-227. [CrossRef]

71. Swisher, H.E. Avocado oil. J. Am. Oil Chem. Soc. 1988, 65, 1704-1706. [CrossRef]

72. Murray, M.T.; Pizzorno, J. The Encyclopedia of Healing Foods; Simon and Schuster: NewYork, NY, USA, 2010.

73. Lidia, D.-A.; Alicia, O.-M.; Felipe, G.-O. Avocado. In Tropical and Subtropical Fruits; Muhammad, S., Ed.; Wiley: Hoboken, NJ, USA, 2012; Volume 1, pp. 435-454.

74. Dabas, D.; Shegog, R.M.; Ziegler, G.R.; Lambert, J.D. Avocado (Persea americana) seed as a source of bioactive phytochemicals. Curr. Pharm. Des. 2013, 19, 6133-6140. [CrossRef]

75. Bauman, H.; Moyer, T. Food as Medicine: Avocado (Persea americana, Lauraceae). In HerbalEGram; American Botanical Council: Austin, TX, USA, 2017; Volume 14.

76. Eisenhauer, B.; Natoli, S.; Liew, G.; Flood, V.M. Lutein and Zeaxanthin-Food Sources, Bioavailability and Dietary Variety in Age-Related Macular Degeneration Protection. Nutrients 2017, 9, 120. [CrossRef]

77. Lichtenstein Alice, H.; Deckelbaum Richard, J. Stanol/Sterol Ester-Containing Foods and Blood Cholesterol Levels. Circulation 2001, 103, 1177-1179. [CrossRef] [PubMed]

78. Weihrauch, J.L.; Gardner, J.M. Sterol content of foods of plant origin. J. Am. Diet. Assoc. 1978, 73, 39-47. [PubMed]

79. Duester, K.C. Avocado fruit is a rich source of beta-sitosterol. J. Am. Diet. Assoc. 2001, 101, $404-405$. [CrossRef]

80. Honarbakhsh, S.; Schachter, M. Vitamins and cardiovascular disease. Br. J. Nutr. 2009, 101, $1113-1131$. [CrossRef] [PubMed]

81. Bhuyan, D.J.; Vuong, Q.V.; Chalmers, A.C.; van Altena, I.A.; Bowyer, M.C.; Scarlett, C.J. Investigation of phytochemicals and antioxidant capacity of selected Eucalyptus species using conventional extraction. Chem. Pap. 2016, 70, 567-575. [CrossRef]

82. Fu, L.; Xu, B.T.; Xu, X.R.; Qin, X.S.; Gan, R.Y.; Li, H.B. Antioxidant capacities and total phenolic contents of 56 wild fruits from South China. Molecules 2010, 15, 8602-8617. [CrossRef] [PubMed]

83. Vázquez, G.; Santos, J.; Freire, M.S.; Antorrena, G.; González-Álvarez, J. Extraction of antioxidants from eucalyptus (Eucalyptus globulus) bark. Wood Sci. Technol. 2012, 46, 443-457. [CrossRef]

84. Wang, W.; Bostic, T.R.; Gu, L. Antioxidant capacities, procyanidins and pigments in avocados of different strains and cultivars. Food Chem. 2010, 122, 1193-1198. [CrossRef]

85. Wang, M.; Zheng, Y.; Khuong, T.; Lovatt, C.J. Effect of harvest date on the nutritional quality and antioxidant capacity in 'Hass' avocado during storage. Food Chem. 2012, 135, 694-698. [CrossRef]

86. Segovia, F.J.; Corral-Pérez, J.J.; Almajano, M.P. Avocado seed: Modeling extraction of bioactive compounds. Ind. Crop. Prod. 2016, 85, 213-220. [CrossRef]

87. Boyadzhieva, S.; Georgieva, S.; Angelov, G. Optimization of the extraction of natural antioxidants from avocado seeds. Bulg. Chem. Commun. 2018, 50, 80-84.

88. Boyadzhieva, S.; Georgieva, S.; Angelov, G. Recovery of antioxidant phenolic compounds from avocado peels by solvent extraction. Bulg. Chem. Commun. 2018, 50, 83-89.

89. Di Stefano, V.; Avellone, G.; Bongiorno, D.; Indelicato, S.; Massenti, R.; Lo Bianco, R. Quantitative evaluation of the phenolic profile in fruits of six avocado (Persea americana) cultivars by ultra-high-performance liquid chromatography-heated electrospray-mass spectrometry. Int. J. Food Prop. 2017, 20, 1302-1312. [CrossRef]

90. Figueroa, J.G.; Borrás-Linares, I.; Lozano-Sánchez, J.; Segura-Carretero, A. Comprehensive identification of bioactive compounds of avocado peel by liquid chromatography coupled to ultra-high-definition accurate-mass Q-TOF. Food Chem. 2018, 245, 707-716. [CrossRef] [PubMed] 
91. Figueroa, J.G.; Borrás-Linares, I.; Lozano-Sánchez, J.; Segura-Carretero, A. Comprehensive characterization of phenolic and other polar compounds in the seed and seed coat of avocado by HPLC-DAD-ESI-QTOF-MS. Food Res. Int. 2018, 105, 752-763. [CrossRef] [PubMed]

92. Hurtado-Fernandez, E.; Carrasco-Pancorbo, A.; Fernandez-Gutierrez, A. Profiling LC-DAD-ESI-TOF MS method for the determination of phenolic metabolites from avocado (Persea americana). J. Agric. Food Chem. 2011, 59, 2255-2267. [CrossRef] [PubMed]

93. Hurtado-Fernández, E.; Pacchiarotta, T.; Mayboroda, O.A.; Fernández-Gutiérrez, A.; Carrasco-Pancorbo, A. Quantitative characterization of important metabolites of avocado fruit by gas chromatography coupled to different detectors (APCI-TOF MS and FID). Food Res. Int. 2014, 62, 801-811. [CrossRef]

94. Kosińska, A.; Karamać, M.; Estrella, I.; Hernández, T.; Bartolomé, B.; Dykes, G.A. Phenolic Compound Profiles and Antioxidant Capacity of Persea americana Mill. Peels and Seeds of Two Varieties. J. Agric. Food Chem. 2012, 60, 4613-4619. [CrossRef] [PubMed]

95. Lima, C.R.; Vasconcelos, C.F.; Costa-Silva, J.H.; Maranhao, C.A.; Costa, J.; Batista, T.M.; Carneiro, E.M.; Soares, L.A.; Ferreira, F.; Wanderley, A.G. Anti-diabetic activity of extract from Persea americana Mill. leaf via the activation of protein kinase B (PKB/Akt) in streptozotocin-induced diabetic rats. J. Ethnopharmacol. 2012, 141, 517-525. [CrossRef]

96. López-Cobo, A.; Gómez-Caravaca, A.M.; Pasini, F.; Caboni, M.F.; Segura-Carretero, A.; Fernández-Gutiérrez, A. HPLC-DAD-ESI-QTOF-MS and HPLC-FLD-MS as valuable tools for the determination of phenolic and other polar compounds in the edible part and by-products of avocado. Lwt Food Sci. Technol. 2016, 73, 505-513. [CrossRef]

97. Tremocoldi, M.A.; Rosalen, P.L.; Franchin, M.; Massarioli, A.P.; Denny, C.; Daiuto, É.R.; Paschoal, J.A.R.; Melo, P.S.; Alencar, S.M.d. Exploration of avocado by-products as natural sources of bioactive compounds. PLoS ONE 2018, 13, e0192577. [CrossRef]

98. Alkhalf, M.I.; Alansari, W.S.; Ibrahim, E.A.; Elhalwagy, M.E.A. Anti-oxidant, anti-inflammatory and anti-cancer activities of avocado (Persea americana) fruit and seed extract. J. King Saud Univ. Sci. 2018. [CrossRef]

99. Amado, D.A.V.; Helmann, G.A.B.; Detoni, A.M.; Carvalho, S.L.C.D.; Aguiar, C.M.D.; Martin, C.A.; Tiuman, T.S.; Cottica, S.M. Antioxidant and antibacterial activity and preliminary toxicity analysis of four varieties of avocado (Persea americana Mill.). Braz. J. Food Technol. 2019, 22. [CrossRef]

100. Bertling, I.; Tesfay, S.; Bower, J. Antioxidants in 'Hass' avocado. South Afr. Avocado Grow. Assoc. Yearb. 2007, 30, 17-19.

101. Calderón-Oliver, M.; Escalona-Buendía, H.B.; Medina-Campos, O.N.; Pedraza-Chaverri, J.; Pedroza-Islas, R.; Ponce-Alquicira, E. Optimization of the antioxidant and antimicrobial response of the combined effect of nisin and avocado byproducts. Lwt-Food Sci. Technol. 2016, 65, 46-52. [CrossRef]

102. Daiuto, É.R.; Tremocoldi, M.A.; Alencar, S.M.D.; Vieites, R.L.; Minarelli, P.H. Composição química e atividade antioxidante da polpa e resíduos de abacate 'Hass'. Rev. Bras. Frutic. 2014, 36, 417-424. [CrossRef]

103. Oboh, G.; Adelusi, T.; Akinyemi, A. Inhibitory effect of phenolic extract from leaf and fruit of avocado pear (Persea americana) on $\mathrm{Fe}^{2+}$ induced lipid peroxidation in rats'pancreas in vitro. Futa J. Res. Sci. 2013, 2, 276-286.

104. Rodriguez-Carpena, J.G.; Morcuende, D.; Andrade, M.J.; Kylli, P.; Estevez, M. Avocado (Persea americana Mill.) phenolics, in vitro antioxidant and antimicrobial activities, and inhibition of lipid and protein oxidation in porcine patties. J. Agric. Food Chem. 2011, 59, 5625-5635. [CrossRef] [PubMed]

105. Soong, Y.-Y.; Barlow, P.J. Antioxidant activity and phenolic content of selected fruit seeds. Food Chem. 2004, 88, 411-417. [CrossRef]

106. Vinha, A.F.; Moreira, J.; Barreira, S.V. Physicochemical parameters, phytochemical composition and antioxidant activity of the algarvian avocado (Persea americana Mill.). J. Agric. Sci. 2013, 5, 100. [CrossRef]

107. Hurtado-Fernández, E.; Pacchiarotta, T.; Gómez-Romero, M.; Schoenmaker, B.; Derks, R.; Deelder, A.M.; Mayboroda, O.A.; Carrasco-Pancorbo, A.; Fernández-Gutiérrez, A. Ultra high performance liquid chromatography-time of flight mass spectrometry for analysis of avocado fruit metabolites: Method evaluation and applicability to the analysis of ripening degrees. J. Chromatogr. A 2011, 1218, 7723-7738. [CrossRef] 
108. Villa-Rodríguez, J.A.; Molina-Corral, F.J.; Ayala-Zavala, J.F.; Olivas, G.I.; González-Aguilar, G.A. Effect of maturity stage on the content of fatty acids and antioxidant activity of 'Hass' avocado. Food Res. Int. 2011, 44, 1231-1237. [CrossRef]

109. Segura, N.; Amarillo, M.; Martinez, N.; Grompone, M. Improvement in the extraction of Hass avocado virgin oil by ultrasound application. J. Food Res. 2018, 7, 106-113. [CrossRef]

110. Lu, Q.Y.; Zhang, Y.; Wang, Y.; Wang, D.; Lee, R.P.; Gao, K.; Byrns, R.; Heber, D. California Hass avocado: Profiling of carotenoids, tocopherol, fatty acid, and fat content during maturation and from different growing areas. J. Agric. Food Chem. 2009, 57, 10408-10413. [CrossRef] [PubMed]

111. Plaza, L.; Sánchez-Moreno, C.; de Pascual-Teresa, S.; de Ancos, B.; Cano, M.P. Fatty Acids, Sterols, and Antioxidant Activity in Minimally Processed Avocados during Refrigerated Storage. J. Agric. Food Chem. 2009, 57, 3204-3209. [CrossRef] [PubMed]

112. Zhang, Z.; Huber, D.J.; Rao, J. Antioxidant systems of ripening avocado (Persea americana Mill.) fruit following treatment at the preclimacteric stage with aqueous 1-methylcyclopropene. Postharvest Biol. Technol. 2013, 76, 58-64. [CrossRef]

113. Souza, D.S.; Marques, L.G.; Gomes, E.d.B.; Narain, N. Lyophilization of Avocado (Persea americana Mill.): Effect of Freezing and Lyophilization Pressure on Antioxidant Activity, Texture, and Browning of Pulp. Dry. Technol. 2015, 33, 194-204. [CrossRef]

114. Soldera-Silva, A.; Seyfried, M.; Campestrini, L.H.; Zawadzki-Baggio, S.F.; Minho, A.P.; Molento, M.B.; Maurer, J.B.B. Assessment of anthelmintic activity and bio-guided chemical analysis of Persea americana seed extracts. Vet. Parasitol. 2018, 251, 34-43. [CrossRef] [PubMed]

115. Abaide, E.R.; Zabot, G.L.; Tres, M.V.; Martins, R.F.; Fagundez, J.L.; Nunes, L.F.; Druzian, S.; Soares, J.F.; Dal Prá, V.; Silva, J.R.F.; et al. Yield, composition, and antioxidant activity of avocado pulp oil extracted by pressurized fluids. Food Bioprod. Process. 2017, 102, 289-298. [CrossRef]

116. dos Santos, M.A.Z.; Alicieo, T.V.R.; Pereira, C.M.P.; Ramis-Ramos, G.; Mendonça, C.R.B. Profile of Bioactive Compounds in Avocado Pulp Oil: Influence of the Drying Processes and Extraction Methods. J. Am. Oil Chem. Soc. 2014, 91, 19-27. [CrossRef]

117. Prabath Pathirana, U.; Sekozawa, Y.; Sugaya, S.; Gemma, H. Changes in lipid oxidation stability and antioxidant properties of avocado in response to 1-MCP and low oxygen treatment under low-temperature storage. Int. Food Res. J. 2013, 20, 1065-1075.

118. Foudjo, B.U.S.; Kansci, G.; Fokou, E.; Genot, C. Prediction of critical times for water-extracted avocado oil heated at high temperatures. Int. J.Biol. Chem. Sci. 2018, 12, 2053-2064. [CrossRef]

119. Corrales-García, J.E.; del Rosario García-Mateos, M.; Martínez-López, E.; Barrientos-Priego, A.F.; Ybarra-Moncada, M.C.; Ibarra-Estrada, E.; Méndez-Zúñiga, S.M.; Becerra-Morales, D. Anthocyanin and Oil Contents, Fatty Acids Profiles and Antioxidant Activity of Mexican Landrace Avocado Fruits. Plant Foods Hum. Nutr. 2019, 74, 210-215. [CrossRef]

120. Corzzini, S.C.S.; Barros, H.D.F.Q.; Grimaldi, R.; Cabral, F.A. Extraction of edible avocado oil using supercritical CO2 and a CO2/ethanol mixture as solvents. J. Food Eng. 2017, 194, 40-45. [CrossRef]

121. Krumreich, F.D.; Borges, C.D.; Mendonça, C.R.B.; Jansen-Alves, C.; Zambiazi, R.C. Bioactive compounds and quality parameters of avocado oil obtained by different processes. Food Chem. 2018, 257, 376-381. [CrossRef]

122. Rodriguez-Sanchez, D.; Silva-Platas, C.; Rojo, R.P.; Garcia, N.; Cisneros-Zevallos, L.; Garcia-Rivas, G.; Hernandez-Brenes, C. Activity-guided identification of acetogenins as novel lipophilic antioxidants present in avocado pulp (Persea americana). J. Chromatogr. B 2013, 942-943, 37-45. [CrossRef]

123. Gómez, F.S.; Sánchez, S.P.; Iradi, M.G.G.; Azman, N.A.M.; Almajano, M.P. Avocado Seeds: Extraction Optimization and Possible Use as Antioxidant in Food. Antioxidants 2014, 3, 439-454. [CrossRef]

124. Kingne, F.K.; Tsafack, H.D.; Boungo, G.T.; Mboukap, A.; Azia, A. Phenolic Content and Antioxidant Activity of Young and Mature Mango (Mangifera indica) and Avocado (Persea americana) Leaves Extracts. J. Food. Stab. 2018, 1, 14-27.

125. Tan, C.X.; Chong, G.H.; Hamzah, H.; Ghazali, H.M. Characterization of Virgin Avocado Oil Obtained via Advanced Green Techniques. Eur. J. Lipid Sci. Technol. 2018, 120, 1800170. [CrossRef]

126. Princwill-Ogbonna, I.; Ogbonna, P.; Ogujiofor, I. Proximate Composition, Vitamin, Mineral and biologically Active Compounds Levels in Leaves of Mangifera indica (Mango), Persea americana (Avocado pea), and Annona muricata (Sour sop). J. Appl. Sci.Environ. Manag. 2019, 23, 65-74. [CrossRef] 
127. Nabavi, S.F.; Nabavi, S.M.N.; Setzer, W.; Nabavi, S.A.; Nabavi, S.A.; Ebrahimzadeh, M.A. Antioxidant and antihemolytic activity of lipid-soluble bioactive substances in avocado fruits. Fruits 2013, 68, 185-193. [CrossRef]

128. Garcia-Alonso, M.; de Pascual-Teresa, S.; Santos-Buelga, C.; Rivas-Gonzalo, J.C. Evaluation of the antioxidant properties of fruits. Food Chem. 2004, 84, 13-18. [CrossRef]

129. Oboh, G.; Odubanjo, V.O.; Bello, F.; Ademosun, A.O.; Oyeleye, S.I.; Nwanna, E.E.; Ademiluyi, A.O. Aqueous extracts of avocado pear (Persea americana Mill.) leaves and seeds exhibit anti-cholinesterases and antioxidant activities in vitro. J. Basic Clin. Physiol. Pharmacol. 2016, 27, 131-140. [CrossRef] [PubMed]

130. Nagaraj, M.; Sandhya, V.; Supriya, G.; Manju, R.; Pranitha, K.; Shivaji, B.; Lalitha, V.; Kiran, B. Antioxidant and antibacterial activity of avocado (Persea gratissima Gaertner.) seed extract. World Appl. Sci. J. 2010, 9 , 695-698.

131. Wang, C.Y.; Bai, X.Y.; Wang, C.H. Traditional Chinese medicine: A treasured natural resource of anticancer drug research and development. Am. J. Chin. Med. 2014, 42, 543-559. [CrossRef] [PubMed]

132. Bhuyan, D.J.; Sakoff, J.; Bond, D.R.; Predebon, M.; Vuong, Q.V.; Chalmers, A.C.; van Altena, I.A.; Bowyer, M.C.; Scarlett, C.J. In vitro anticancer properties of selected Eucalyptus species. In Vitro Cell. Dev. Biol. Anim. 2017, 53, 604-615. [CrossRef] [PubMed]

133. Zhang, Y.; Liang, Y.; He, C. Anticancer activities and mechanisms of heat-clearing and detoxicating traditional Chinese herbal medicine. Chin. Med. 2017, 12, 20. [CrossRef] [PubMed]

134. Bhuyan, D.J.; Vuong, Q.V.; Chalmers, A.C.; Bowyer, M.C.; Scarlett, C.J. An array of bioactive compounds from Australian eucalypts and their relevance in pancreatic cancer therapeutics. Pancreas 2018, 47, 690-707. [CrossRef] [PubMed]

135. Wang, H.; Khor, T.O.; Shu, L.; Su, Z.-Y.; Fuentes, F.; Lee, J.-H.; Kong, A.-N.T. Plants vs. cancer: A review on natural phytochemicals in preventing and treating cancers and their druggability. Anticancer Agents Med. Chem. 2012, 12, 1281-1305. [CrossRef] [PubMed]

136. Bhuyan, D.J.; Vuong, Q.V.; Bond, D.R.; Chalmers, A.C.; Bowyer, M.C.; Scarlett, C.J. Eucalyptus microcorys leaf extract derived HPLC-fraction reduces the viability of MIA PaCa-2 cells by inducing apoptosis and arresting cell cycle. Biomed. Pharmacother. 2018, 105, 449-460. [CrossRef]

137. Mooz, E.D.; Gaiano, N.M.; Shimano, M.Y.H.; Amancio, R.D.; Spoto, M.H.F. Physical and chemical characterization of the pulp of different varieties of avocado targeting oil extraction potential. Food Sci. Technol 2012, 32, 274-280. [CrossRef]

138. Bonilla-Porras, A.R.; Salazar-Ospina, A.; Jimenez-Del-Rio, M.; Pereanez-Jimenez, A.; Velez-Pardo, C. Pro-apoptotic effect of Persea americana var. Hass (avocado) on Jurkat lymphoblastic leukemia cells. Pharm. Biol. 2013. [CrossRef]

139. Butt, A.J.; Roberts, C.G.; Seawright, A.A.; Oelrichs, P.B.; MacLeod, J.K.; Liaw, T.Y.E.; Kavallaris, M.; Somers-Edgar, T.J.; Lehrbach, G.M.; Watts, C.K.; et al. A novel plant toxin, persin, with in vivo activity in the mammary gland, induces Bim-dependent apoptosis in human breast cancer cells. Mol. Cancer Ther. 2006, 5, 2300-2309. [CrossRef] [PubMed]

140. Dabas, D.; Elias, R.J.; Ziegler, G.R.; Lambert, J.D. In Vitro Antioxidant and Cancer Inhibitory Activity of a Colored Avocado Seed Extract. Int. J. Food Sci. 2019, 2019, 7. [CrossRef] [PubMed]

141. Ding, H.; Chin, Y.-W.; Kinghorn, A.D.; D'Ambrosio, S.M. Chemopreventive characteristics of avocado fruit. Semin. Cancer Biol. 2007, 17, 386-394. [CrossRef]

142. Ding, H.; Han, C.; Guo, D.; Chin, Y.W.; Ding, Y.; Kinghorn, A.D.; D'Ambrosio, S.M. Selective induction of apoptosis of human oral cancer cell lines by avocado extracts via a ROS-mediated mechanism. Nutr. Cancer 2009, 61, 348-356. [CrossRef]

143. Guzman-Rodriguez, J.J.; Lopez-Gomez, R.; Salgado-Garciglia, R.; Ochoa-Zarzosa, A.; Lopez-Meza, J.E. The defensin from avocado (Persea americana var. drymifolia) PaDef induces apoptosis in the human breast cancer cell line MCF-7. Biomed. Pharmacother. 2016, 82, 620-627. [CrossRef] [PubMed]

144. Lee, S.-G.; Yu, M.-H.; Lee, S.-P.; Lee, I.-S. Antioxidant activities and induction of apoptosis by methanol extracts from avocado. J. Korean Soc. Food Sci. Nutr. 2008, 37, 269-275. [CrossRef]

145. Leon, L.G.; Carballo, R.M.; Vega-Hernandez, M.C.; Miranda, P.O.; Martin, V.S.; Padron, J.I.; Padron, J.M. $\beta$ '-Hydroxy-alpha, $\beta$-unsaturated ketones: A new pharmacophore for the design of anticancer drugs. Part 2. ChemMedChem 2008, 3, 1740-1747. [CrossRef] 
146. Aubrey, B.J.; Kelly, G.L.; Janic, A.; Herold, M.J.; Strasser, A. How does p53 induce apoptosis and how does this relate to p53-mediated tumour suppression? Cell Death Differ. 2017, 25, 104. [CrossRef]

147. Gondi, C.S.; Dinh, D.H.; Klopfenstein, J.D.; Gujrati, M.; Rao, J.S. MMP-2 downregulation mediates differential regulation of cell death via ErbB-2 in glioma xenografts. Int. J. Oncol. 2009, 35, 257-263.

148. Valacca, C.; Tassone, E.; Mignatti, P. TIMP-2 Interaction with MT1-MMP Activates the AKT Pathway and Protects Tumor Cells from Apoptosis. PLoS ONE 2015, 10, e0136797. [CrossRef]

149. Roberts, C.G.; Gurisik, E.; Biden, T.J.; Sutherland, R.L.; Butt, A.J. Synergistic cytotoxicity between tamoxifen and the plant toxin persin in human breast cancer cells is dependent on Bim expression and mediated by modulation of ceramide metabolism. Mol. Cancer Ther. 2007, 6, 2777-2785. [CrossRef] [PubMed]

150. Hata, A.N.; Engelman, J.A.; Faber, A.C. The BCL2 Family: Key Mediators of the Apoptotic Response to Targeted Anticancer Therapeutics. Cancer Discov. 2015, 5, 475-487. [CrossRef] [PubMed]

151. O'Connor, L.; Strasser, A.; O’Reilly, L.A.; Hausmann, G.; Adams, J.M.; Cory, S.; Huang, D.C. Bim: A novel member of the Bcl-2 family that promotes apoptosis. Embo J. 1998, 17, 384-395. [CrossRef] [PubMed]

152. Li, R.; Moudgil, T.; Ross, H.J.; Hu, H.-M. The BH3-only proapoptotic protein Bim directly links the microtubule poison Paclitaxel to mitochondrial damage and apoptosis. Cancer Res. 2004, 64, 1296.

153. Flores-Alvarez, L.J.; Guzman-Rodriguez, J.J.; Lopez-Gomez, R.; Salgado-Garciglia, R.; Ochoa-Zarzosa, A.; Lopez-Meza, J.E. PaDef defensin from avocado (Persea americana var. drymifolia) is cytotoxic to K562 chronic myeloid leukemia cells through extrinsic apoptosis. Int. J. Biochem. Cell Biol. 2018, 99, 10-18. [CrossRef] [PubMed]

154. Brooke, D.G.; Shelley, E.J.; Roberts, C.G.; Denny, W.A.; Sutherland, R.L.; Butt, A.J. Synthesis and in vitro evaluation of analogues of avocado-produced toxin (+)-(R)-persin in human breast cancer cells. Bioorg. Med. Chem. 2011, 19, 7033-7043. [CrossRef] [PubMed]

155. Guzmán-Rodríguez, J.J.; López-Gómez, R.; Suárez-Rodríguez, L.M.; Salgado-Garciglia, R.; Rodríguez-Zapata, L.C.; Ochoa-Zarzosa, A.; López-Meza, J.E. Antibacterial activity of defensin PaDef from avocado fruit (Persea americana var. drymifolia) expressed in endothelial cells against Escherichia coli and Staphylococcus aureus. Biomed Res. Int. 2013, 2013, 986273. [CrossRef]

156. Meneguetti, B.T.; Machado, L.d.S.; Oshiro, K.G.N.; Nogueira, M.L.; Carvalho, C.M.E.; Franco, O.L. Antimicrobial Peptides from Fruits and Their Potential Use as Biotechnological Tools-A Review and Outlook. Front. Microbiol. 2017, 7. [CrossRef]

157. Kulkarni, P.; Paul, R.; Ganesh, N. In Vitro evaluation of genotoxicity of avocado (Persea americana) fruit and leaf extracts in human peripheral lymphocytes. J. Environ. Sci. Health C 2010, 28, 172-187. [CrossRef]

158. Paul, R.; Kulkarni, P.; Ganesh, N. Avocado fruit (Persea americana Mill) exhibits chemo-protective potentiality against cyclophosphamide induced genotoxicity in human lymphocyte culture. J. Exp. Ther. Oncol. 2011, 9, 221-230.

159. Engel, N.; Oppermann, C.; Falodun, A.; Kragl, U. Proliferative effects of five traditional Nigerian medicinal plant extracts on human breast and bone cancer cell lines. J. Ethnopharmacol. 2011, 137, 1003-1010. [CrossRef] [PubMed]

160. Jackson, M.D.; Walker, S.P.; Simpson-Smith, C.M.; Lindsay, C.M.; Smith, G.; McFarlane-Anderson, N.; Bennett, F.I.; Coard, K.C.M.; Aiken, W.D.; Tulloch, T.; et al. Associations of whole-blood fatty acids and dietary intakes with prostate cancer in Jamaica. Cancer Causes Control 2012, 23, 23-33. [CrossRef] [PubMed]

161. Hughes, K.J.; Mayne, S.T.; Blumberg, J.B.; Ribaya-Mercado, J.D.; Johnson, E.J.; Cartmel, B. Plasma Carotenoids and Biomarkers of Oxidative Stress in Patients with prior Head and Neck Cancer. Biomark. Insights 2009, 4, 17-26. [CrossRef]

162. Tamimi, R.M.; Colditz, G.A.; Hankinson, S.E. Circulating carotenoids, mammographic density, and subsequent risk of breast cancer. Cancer Res. 2009, 69, 9323-9329. [CrossRef] [PubMed]

163. Thomson, C.A.; Stendell-Hollis, N.R.; Rock, C.L.; Cussler, E.C.; Flatt, S.W.; Pierce, J.P. Plasma and dietary carotenoids are associated with reduced oxidative stress in women previously treated for breast cancer. Cancer Epidemiol. Biomark. Prev. 2007, 16, 2008-2015. [CrossRef] [PubMed]

164. Jones, D.P.; Coates, R.J.; Flagg, E.W.; Eley, J.W.; Block, G.; Greenberg, R.S.; Gunter, E.W.; Jackson, B. Glutathione in foods listed in the National Cancer Institute's Health Habits and History Food Frequency Questionnaire. Nutr. Cancer 1992, 17, 57-75. [CrossRef] [PubMed] 
165. D'Ambrosio, S.M.; Han, C.; Pan, L.; Kinghorn, A.D.; Ding, H. Aliphatic acetogenin constituents of avocado fruits inhibit human oral cancer cell proliferation by targeting the EGFR/RAS/RAF/MEK/ERK1/2 pathway. Biochem. Biophys. Res. Commun. 2011, 409, 465-469. [CrossRef]

166. Vo, T.S.; Le, P.U. Free radical scavenging and anti-proliferative activities of avocado (Persea americana Mill.) seed extract. Asian Pac. J. Trop. Biomed. 2019, 9,91.

167. Widiyastuti, Y.; Pratiwi, R.; Riyanto, S.; Wahyuono, S. Cytotoxic Activity and Apoptosis Induction of Avocado (Perseaamericana) Seed Extract on MCF-7 Cancer Cell Line. Indones. J. Biotechnol. 2018, 23, 61-67. [CrossRef]

168. Salazar, L.; López, M.J.V.; Grijalva, M.; Castillo, L.; Maldonado, A. Biological Effect of Organically Coated Grias neuberthii and Persea americana Silver Nanoparticles on HeLa and MCF-7 Cancer Cell Lines. J. Nanotechnol. 2018, 2018, 11. [CrossRef]

169. Ant, A.; Avcý, A.; Genç, M.; Ýnal, E.; Tunçel, Ü.; Pencan, Z. Avocado leaf extract activates Adenosine Deaminase (ADA) in Larynx cancer tissues. Acta Oncol. Tur. 2018, 51, 199-204. [CrossRef]

170. Abubakar, A.N.F.; Achmadi, S.S.; Suparto, I.H. Triterpenoid of avocado (Persea americana) seed and its cytotoxic activity toward breast MCF-7 and liver HepG2 cancer cells. Asian Pac. J. Trop. Biomed. 2017, 7, 397-400. [CrossRef]

171. Vahedi Larijani, L.; Ghasemi, M.; AbedianKenari, S.; Naghshvar, F. Evaluating the effect of four extracts of avocado fruit on esophageal squamous carcinoma and colon adenocarcinoma cell lines in comparison with peripheral blood mononuclear cells. Acta Med. Iran. 2014, 52, 201-205. [PubMed]

172. Khalifa, N.S.; Barakat, H.S.; Elhallouty, S.; Salem, D. Effect of the Water Extracts of Avocado Fruit and Cherimoya Leaf on Four Human Cancer Cell Lines and Vicia Faba Root Tip Cells. J. Agric. Sci. 2013, 5, 245. [CrossRef]

173. Kim, O.K.; Murakami, A.; Takahashi, D.; Nakamura, Y.; Torikai, K.; Kim, H.W.; Ohigashi, H. An avocado constituent, persenone A, suppresses expression of inducible forms of nitric oxide synthase and cyclooxygenase in macrophages, and hydrogen peroxide generation in mouse skin. Biosci. Biotechnol. Biochem. 2000, 64, 2504-2507. [CrossRef] [PubMed]

174. Papoutsis, K.; Mathioudakis, M.M.; Hasperué, J.H.; Ziogas, V. Non-chemical treatments for preventing the postharvest fungal rotting of citrus caused by Penicillium digitatum (green mold) and Penicillium italicum (blue mold). Trends Food Sci. Technol. 2019, 86, 479-491. [CrossRef]

175. Athaydes, B.R.; Alves, G.M.; Assis, A.L.E.M.D.; Gomes, J.V.D.; Rodrigues, R.P.; Campagnaro, B.P.; Nogueira, B.V.; Silveira, D.; Kuster, R.M.; Pereira, T.M.C.; et al. Avocado seeds (Persea americana Mill.) prevents indomethacin-induced gastric ulcer in mice. Food Res. Int. 2019, 119, 751-760. [CrossRef]

176. Raymond Chia, T.W.; Dykes, G.A. Antimicrobial activity of crude epicarp and seed extracts from mature avocado fruit (Persea americana) of three cultivars. Pharm. Biol. 2010, 48, 753-756. [CrossRef]

177. Salinas-Salazar, C.; Hernández-Brenes, C.; Rodríguez-Sánchez, D.G.; Castillo, E.C.; Navarro-Silva, J.M.; Pacheco, A. Inhibitory Activity of Avocado Seed Fatty Acid Derivatives (Acetogenins) Against Listeria Monocytogenes. J. Food Sci. 2017, 82, 134-144. [CrossRef]

178. Cardoso, P.F.; Scarpassa, J.A.; Pretto-Giordano, L.G.; Otaguiri, E.S.; Yamada-Ogatta, S.F.; Nakazato, G.; Perugini, M.R.E.; Moreira, I.C.; Vilas-Boâs, G.T. Antibacterial activity of avocado extracts (Persea americana Mill.) against streptococcus agalactiae. Phyton 2016, 85, 218-224.

179. Hennessey-Ramos, L.; Murillo-Arango, W.; Guayabo, G.T. Evaluation of a colorant and oil extracted from avocado waste as functional components of a liquid soap formulation. Rev. Fac. Nac. Agron. Medellin 2019, 72, 8855-8862. [CrossRef]

180. Bamoniri, A.; Ebrahimabadi, A.H.; Mazoochi, A.; Behpour, M.; Kashi, F.J.; Batooli, H. Antioxidant and antimicrobial activity evaluation and essential oil analysis of Semenovia tragioides Boiss. from Iran. Food Chem. 2010, 122, 553-558. [CrossRef]

181. Bouic, P.J.; Etsebeth, S.; Liebenberg, R.W.; Albrecht, C.F.; Pegel, K.; Van Jaarsveld, P.P. beta-Sitosterol and beta-sitosterol glucoside stimulate human peripheral blood lymphocyte proliferation: Implications for their use as an immunomodulatory vitamin combination. Int. Immunopharmacol. 1996, 18, 693-700. [CrossRef]

182. Simpson, D.; Amos, S. Chapter 12-Other Plant Metabolites. In Pharmacognosy; Badal, S., Delgoda, R., Eds.; Academic Press: Boston, MA, USA, 2017; pp. 267-280. 
183. Pacheco, A.; Rodríguez-Sánchez, D.G.; Villarreal-Lara, R.; Navarro-Silva, J.M.; Senés-Guerrero, C.; Hernández-Brenes, C. Stability of the antimicrobial activity of acetogenins from avocado seed, under common food processing conditions, against Clostridium sporogenes vegetative cell growth and endospore germination. Int. J. Food Sci. Technol. 2017, 52, 2311-2323. [CrossRef]

184. Singh, B.; Singh, J.P.; Kaur, A.; Singh, N. Antimicrobial potential of pomegranate peel: A review. Int. J. Food Sci. Technol. 2019, 54, 959-965. [CrossRef]

185. Adeyemi, O.; Okpo, S.; O Ogunti, O. Analgesic and anti-inflammatory effects of Persea americana Mill (Lauraceae). Fitoterapia 2002, 73, 375-380. [CrossRef]

186. de Oliveira, A.P.; Franco, E.d.S.; Rodrigues Barreto, R.; Cordeiro, D.P.; de Melo, R.G.; de Aquino, C.M.F.; e Silva, A.A.R.; de Medeiros, P.L.; et al. Effect of Semisolid Formulation of Persea Americana Mill (Avocado) Oil on Wound Healing in Rats. Evid. Based Complement. Alternat. Med. 2013, 2013, 8. [CrossRef] [PubMed]

187. Kim, Y.; Oh, H.-C.; Park, J.W.; Kim, I.-S.; Kim, J.-Y.; Kim, K.-C.; Chae, D.-S.; Jo, W.-L.; Song, J.-H. Diagnosis and Treatment of Inflammatory Joint Disease. Hip Pelvis 2017, 29, 211-222. [CrossRef]

188. Berenbaum, F. Osteoarthritis as an inflammatory disease (osteoarthritis is not osteoarthrosis!). Osteoarthr. Cartil. 2013, 21, 16-21. [CrossRef]

189. Ownby, S.L.; Fortuno, L.V.; Au, A.Y.; Grzanna, M.W.; Rashmir-Raven, A.M.; Frondoza, C.G. Expression of pro-inflammatory mediators is inhibited by an avocado/soybean unsaponifiables and epigallocatechin gallate combination. J. Inflamm. 2014, 11, 8. [CrossRef]

190. Gabay, O.; Gosset, M.; Levy, A.; Salvat, C.; Sanchez, C.; Pigenet, A.; Sautet, A.; Jacques, C.; Berenbaum, F. Stress-induced signaling pathways in hyalin chondrocytes: Inhibition by Avocado-Soybean Unsaponifiables (ASU). Osteoarthr. Cartil. 2008, 16, 373-384. [CrossRef] [PubMed]

191. Angermann, P. Avocado/soybean unsaponifiables in the treatment of knee and hip osteoarthritis. Ugeskr. Laeger 2005, 167, 3023-3025. [PubMed]

192. Henrotin, Y.E.; Labasse, A.H.; Jaspar, J.M.; De Groote, D.D.; Zheng, S.X.; Guillou, G.B.; Reginster, J.Y. Effects of three avocado/soybean unsaponifiable mixtures on metalloproteinases, cytokines and prostaglandin E2 production by human articular chondrocytes. Clin. Rheumatol. 1998, 17, 31-39. [CrossRef] [PubMed]

193. Khayyal, M.T.; el-Ghazaly, M.A. The possible "chondroprotective" effect of the unsaponifiable constituents of avocado and soya in vivo. Drugs Exp. Clin. Res. 1998, 24, 41-50. [PubMed]

194. Christiansen, B.A.; Bhatti, S.; Goudarzi, R.; Emami, S. Management of Osteoarthritis with Avocado/Soybean Unsaponifiables. Cartilage 2015, 6, 30-44. [CrossRef] [PubMed]

195. Goudarzi, R.; Taylor, J.F.; Yazdi, P.G.; Pedersen, B.A. Effects of Arthrocen, an avocado/soy unsaponifiables agent, on inflammatory mediators and gene expression in human chondrocytes. FEBS Open Bio 2017, 7, 187-194. [CrossRef] [PubMed]

196. Au, R.Y.; Al-Talib, T.K.; Au, A.Y.; Phan, P.V.; Frondoza, C.G. Avocado soybean unsaponifiables (ASU) suppress TNF- $\alpha$, IL-1 $\beta$, COX-2, iNOS gene expression, and prostaglandin E2 and nitric oxide production in articular chondrocytes and monocyte/macrophages. Osteoarthr. Cartil. 2007, 15, 1249-1255. [CrossRef]

197. Oliveira, G.J.P.L.; Paula, L.G.F.; Souza, J.A.C.; Spin-Neto, R.; Stavropoulos, A.; Marcantonio, R.A.C. Effect of avocado/soybean unsaponifiables on ligature-induced bone loss and bone repair after ligature removal in rats. J. Periodontal Res. 2016, 51, 332-341. [CrossRef] [PubMed]

198. Lippiello, L.; Nardo, J.V.; Harlan, R.; Chiou, T. Metabolic Effects of Avocado/Soy Unsaponifiables on Articular Chondrocytes. Evid. Based Complement. Alternat. Med. 2008, 5, 191-197. [CrossRef]

199. Kawcak, C.E.; Frisbie, D.D.; McIlwraith, C.W.; Werpy, N.M.; Park, R.D. Evaluation of avocado and soybean unsaponifiable extracts for treatment of horses with experimentally induced osteoarthritis. Am. J. Vet. Res. 2007, 68, 598-604. [CrossRef]

200. Blotman, F.; Maheu, E.; Wulwik, A.; Caspard, H.; Lopez, A. Efficacy and safety of avocado/soybean unsaponifiables in the treatment of symptomatic osteoarthritis of the knee and hip. A prospective, multicenter, three-month, randomized, double-blind, placebo-controlled trial. Rev. Rhum. Engl. Ed. 1997, 64, 825-834. [PubMed]

201. Lequesne, M.; Maheu, E.; Cadet, C.; Dreiser, R.-L. Structural effect of avocado/soybean unsaponifiables on joint space loss in osteoarthritis of the hip. Arthritis Care Res. 2002, 47, 50-58. [CrossRef] [PubMed] 
202. Maheu, E.; Cadet, C.; Marty, M.; Moyse, D.; Kerloch, I.; Coste, P.; Dougados, M.; Mazieres, B.; Spector, T.D.; Halhol, H.; et al. Randomised, controlled trial of avocado-soybean unsaponifiable (Piascledine) effect on structure modification in hip osteoarthritis: The ERADIAS study. Ann. Rheum. Dis. 2014, 73, 376-384. [CrossRef] [PubMed]

203. Catunda, I.S.; Vasconcelos, B.C.d.E.; Andrade, E.S.d.S.; Costa, D.F.N. Clinical effects of an avocado-soybean unsaponifiable extract on arthralgia and osteoarthritis of the temporomandibular joint: Preliminary study. Int. J. Oral Maxillofac. Surg. 2016, 45, 1015-1022. [CrossRef] [PubMed]

204. Heinecke, L.F.; Grzanna, M.W.; Au, A.Y.; Mochal, C.A.; Rashmir-Raven, A.; Frondoza, C.G. Inhibition of cyclooxygenase-2 expression and prostaglandin E2 production in chondrocytes by avocado soybean unsaponifiables and epigallocatechin gallate. Osteoarthr. Cartil. 2010, 18, 220-227. [CrossRef] [PubMed]

205. Frondoza, C.G.; Fortuno, L.V.; Grzanna, M.W.; Ownby, S.L.; Au, A.Y.; Rashmir-Raven, A.M. $\alpha$-Lipoic Acid Potentiates the Anti-Inflammatory Activity of Avocado/Soybean Unsaponifiables in Chondrocyte Cultures. Cartilage 2017, 9, 304-312. [CrossRef]

206. Andriamanalijaona, R.; Benateau, H.; Barre, P.E.; Boumediene, K.; Labbe, D.; Compere, J.F.; Pujol, J.P. Effect of Interleukin-1 $\beta$ on Transforming Growth Factor-Beta and Bone Morphogenetic Protein-2 Expression in Human Periodontal Ligament and Alveolar Bone Cells in Culture: Modulation by Avocado and Soybean Unsaponifiables. J. Periodontol. 2006, 77, 1156-1166. [CrossRef]

207. Oliveira, G.J.P.L.D.; Paula, L.G.F.D.; Souza, J.A.C.D.; Spin-Neto, R.; Stavropoulos, A.; Marcantonio, R.A.C. Effects of avocado/soybean unsaponifiables (ASU) on the treatment of ligature-induced periodontitis in rats. Braz. Oral Res. 2017, 31. [CrossRef]

208. Noorul, H.; Nesar, A.; Zafar, K.; Khalid, M.; Zeeshan, A.; Vartika, S. Health benefits and pharmacology of Persea americana mill. (Avocado). Int. J. Res. Pharmacol. Pharmacother. 2016, 5, 132-141.

209. Grant, W.C. Influence of avocados on serum cholesterol. Proc. Soc. Exp. Biol. Med. 1960, 104, 45-47. [CrossRef]

210. Pieterse, Z.; Jerling, J.C.; Oosthuizen, W.; Kruger, H.S.; Hanekom, S.M.; Smuts, C.M.; Schutte, A.E. Substitution of high monounsaturated fatty acid avocado for mixed dietary fats during an energy-restricted diet: Effects on weight loss, serum lipids, fibrinogen, and vascular function. Nutrition 2005, 21, 67-75. [CrossRef] [PubMed]

211. Fulgoni, V.L., 3rd; Dreher, M.; Davenport, A.J. Avocado consumption is associated with better diet quality and nutrient intake, and lower metabolic syndrome risk in US adults: Results from the National Health and Nutrition Examination Survey (NHANES) 2001-2008. Nutr. J. 2013, 12, 1. [CrossRef] [PubMed]

212. Wien, M.; Haddad, E.; Oda, K.; Sabate, J. A randomized $3 \times 3$ crossover study to evaluate the effect of Hass avocado intake on post-ingestive satiety, glucose and insulin levels, and subsequent energy intake in overweight adults. Nutr. J. 2013, 12, 155. [CrossRef] [PubMed]

213. Silva Caldas, A.P.; Chaves, L.O.; Linhares Da Silva, L.; De Castro Morais, D.; Gonçalves Alfenas, R.d.C. Mechanisms involved in the cardioprotective effect of avocado consumption: A systematic review. Int. J. Food Prop. 2017, 20, 1675-1685. [CrossRef]

214. Carvajal-Zarrabal, O.; Nolasco-Hipolito, C.; Aguilar-Uscanga, M.G.; Melo-Santiesteban, G.; Hayward-Jones, P.M.; Barradas-Dermitz, D.M. Avocado oil supplementation modifies cardiovascular risk profile markers in a rat model of sucrose-induced metabolic changes. Dis. Markers 2014, 2014, 386425. [CrossRef] [PubMed]

215. Heskey, C.; Oda, K.; Sabate, J. Avocado Intake, and Longitudinal Weight and Body Mass Index Changes in an Adult Cohort. Nutrients 2019, 11. [CrossRef] [PubMed]

216. Mahmassani, H.A.; Avendano, E.E.; Raman, G.; Johnson, E.J. Avocado consumption and risk factors for heart disease: A systematic review and meta-analysis. Am. J. Clin. Nutr. 2018, 107, 523-536. [CrossRef] [PubMed]

217. Pahua-Ramos, M.E.; Ortiz-Moreno, A.; Chamorro-Cevallos, G.; Hernandez-Navarro, M.D.; Garduno-Siciliano, L.; Necoechea-Mondragon, H.; Hernandez-Ortega, M. Hypolipidemic effect of avocado (Persea americana Mill) seed in a hypercholesterolemic mouse model. Plant Foods Hum. Nutr. 2012, 67, 10-16. [CrossRef] [PubMed]

218. Foster-Powell, K.; Holt, S.H.; Brand-Miller, J.C. International table of glycemic index and glycemic load values: 2002. Am. J. Clin. Nutr. 2002, 76, 5-56. [CrossRef] [PubMed]

219. Ezejiofor, A.N.; Okorie, A.; Orisakwe, O.E. Hypoglycaemic and tissue-protective effects of the aqueous extract of persea americana seeds on alloxan-induced albino rats. Malays. J. Med. Sci. 2013, 20, 31-39. 
220. Pahua-Ramos, M.E.; Garduno-Siciliano, L.; Dorantes-Alvarez, L.; Chamorro-Cevallos, G.; Herrera-Martinez, J.; Osorio-Esquivel, O.; Ortiz-Moreno, A. Reduced-calorie avocado paste attenuates metabolic factors associated with a hypercholesterolemic-high fructose diet in rats. Plant Foods Hum. Nutr. 2014, 69, 18-24. [CrossRef]

221. Oboh, G.; Isaac, A.T.; Akinyemi, A.J.; Ajani, R.A. Inhibition of key enzymes linked to type 2 diabetes and sodium nitroprusside induced lipid peroxidation in rats' pancreas by phenolic extracts of avocado pear leaves and fruit. Int. J. Biomed. Sci. 2014, 10, 208-216. [PubMed]

222. Park, E.; Edirisinghe, I.; Burton-Freeman, B. Avocado Fruit on Postprandial Markers of Cardio-Metabolic Risk: A Randomized Controlled Dose Response Trial in Overweight and Obese Men and Women. Nutrients 2018, 10, 1287. [CrossRef]

223. U.S. Department of Agriculture. Basic Report: 09038, Avocados, raw, California. In USDA Natl. Nutr. Database Stand. Ref.; 2018. Available online: https://ndb.nal.usda.gov/ndb/foods/show/09038?fgcd=\&manu= $\&$ format $=\&$ count $=\& m a x=25 \&$ offset $=\&$ sort $=$ default $\&$ order $=$ asc $\& q l o o k u p=$ avocado\&ds $=\& q t=\& q p=\& q a=$ $\& q n=\& q=\& i n g=($ accessed on 15 August 2019).

224. Unlu, N.Z.; Bohn, T.; Clinton, S.K.; Schwartz, S.J. Carotenoid absorption from salad and salsa by humans is enhanced by the addition of avocado or avocado oil. J. Nutr. 2005, 135, 431-436. [CrossRef]

225. Tang, G.W.; Qin, J.; Dolnikowski, G.G.; Russell, R.M.; Grusak, M.A. Spinach or carrots can supply significant amounts of vitamin A as assessed by feeding with intrinsically deuterated vegetables. Am. J. Clin. Nutr. 2005, 82, 821-828. [CrossRef]

226. Stahl, W.; van den Berg, H.; Arthur, J.; Bast, A.; Dainty, J.; Faulks, R.M.; Gartner, C.; Haenen, G.; Hollman, P.; Holst, B.; et al. Bioavailability and metabolism. Mol. Asp. Med. 2002, 23, 39-100. [CrossRef]

227. White, W.S.; Zhou, Y.; Crane, A.; Dixon, P.; Quadt, F.; Flendrig, L.M. Modeling the dose effects of soybean oil in salad dressing on carotenoid and fat-soluble vitamin bioavailability in salad vegetables. Am. J. Clin. Nutr. 2017, 106, 1041-1051. [CrossRef] [PubMed]

228. Reboul, E. Absorption of vitamin A and carotenoids by the enterocyte: Focus on transport proteins. Nutrients 2013, 5, 3563-3581. [CrossRef]

229. Kopec, R.E.; Cooperstone, J.L.; Schweiggert, R.M.; Young, G.S.; Harrison, E.H.; Francis, D.M.; Clinton, S.K.; Schwartz, S.J. Avocado consumption enhances human postprandial provitamin A absorption and conversion from a novel high-beta-carotene tomato sauce and from carrots. J. Nutr. 2014, 144, 1158-1166. [CrossRef] [PubMed]

230. Alam, D.S.; Yunus, M.; Aziz, K.M.A.; Wahed, M.A.; van Raaij, J.M.A.; Hautvast, J.G.A.G.; Fuchs, G.J. Effects of dietary fat supplementation during pregnancy/lactation on maternal blood and breastmilk vitamin A in rural Bangladesh. FASEB J. 1999, 13, A895.

231. Brown, M.J.; Ferruzzi, M.G.; Nguyen, M.L.; Cooper, D.A.; Eldridge, A.L.; Schwartz, S.J.; White, W.S. Carotenoid bioavailability is higher from salads ingested with full-fat than with fat-reduced salad dressings as measured with electrochemical detection. Am. J. Clin. Nutr. 2004, 80, 396-403. [CrossRef]

232. Ostlund, R.E.; McGill, J.B.; Zeng, C.M.; Covey, D.F.; Stearns, J.; Stenson, W.F.; Spilburg, C.A. Gastrointestinal absorption and plasma kinetics of soy Delta(5)-phytosterols and phytostanols in humans. Am. J. Physiol. Endocrinol. Metab. 2002, 282, E911-E916. [CrossRef]

233. Ogbe, R.J.; Ochalefu, D.O.; Mafulul, S.G.; Olaniru, O.B. A review on dietary phytosterols: Their occurrence, metabolism and health benefits. Asian J. Plant Sci. Res. 2015, 5, 10-21.

234. Katan, M.B.; Grundy, S.M.; Jones, P.; Law, M.; Miettinen, T.; Paoletti, R.; Participants, S.W. Efficacy and safety of plant stanols and sterols in the management of blood cholesterol levels. Mayo Clin. Proc. 2003, 78, 965-978. [CrossRef]

(C) 2019 by the authors. Licensee MDPI, Basel, Switzerland. This article is an open access article distributed under the terms and conditions of the Creative Commons Attribution (CC BY) license (http://creativecommons.org/licenses/by/4.0/). 